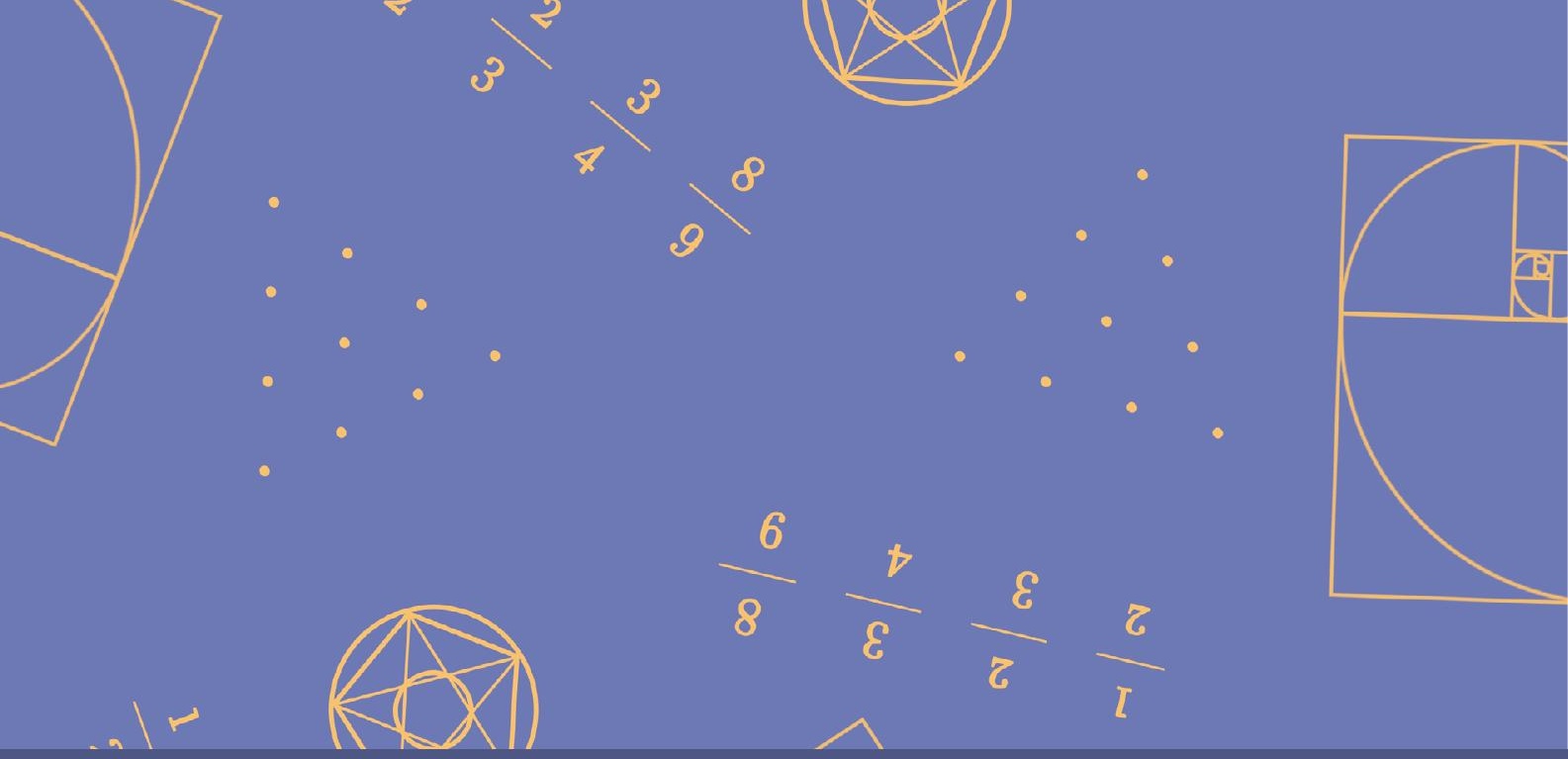

\title{
PITÁGORAS \\ PARA ALÉM DO TEOREMA
}

Sérgio Candido de Gouveia Neto Jean Sebastian Toillier (Orgs.)
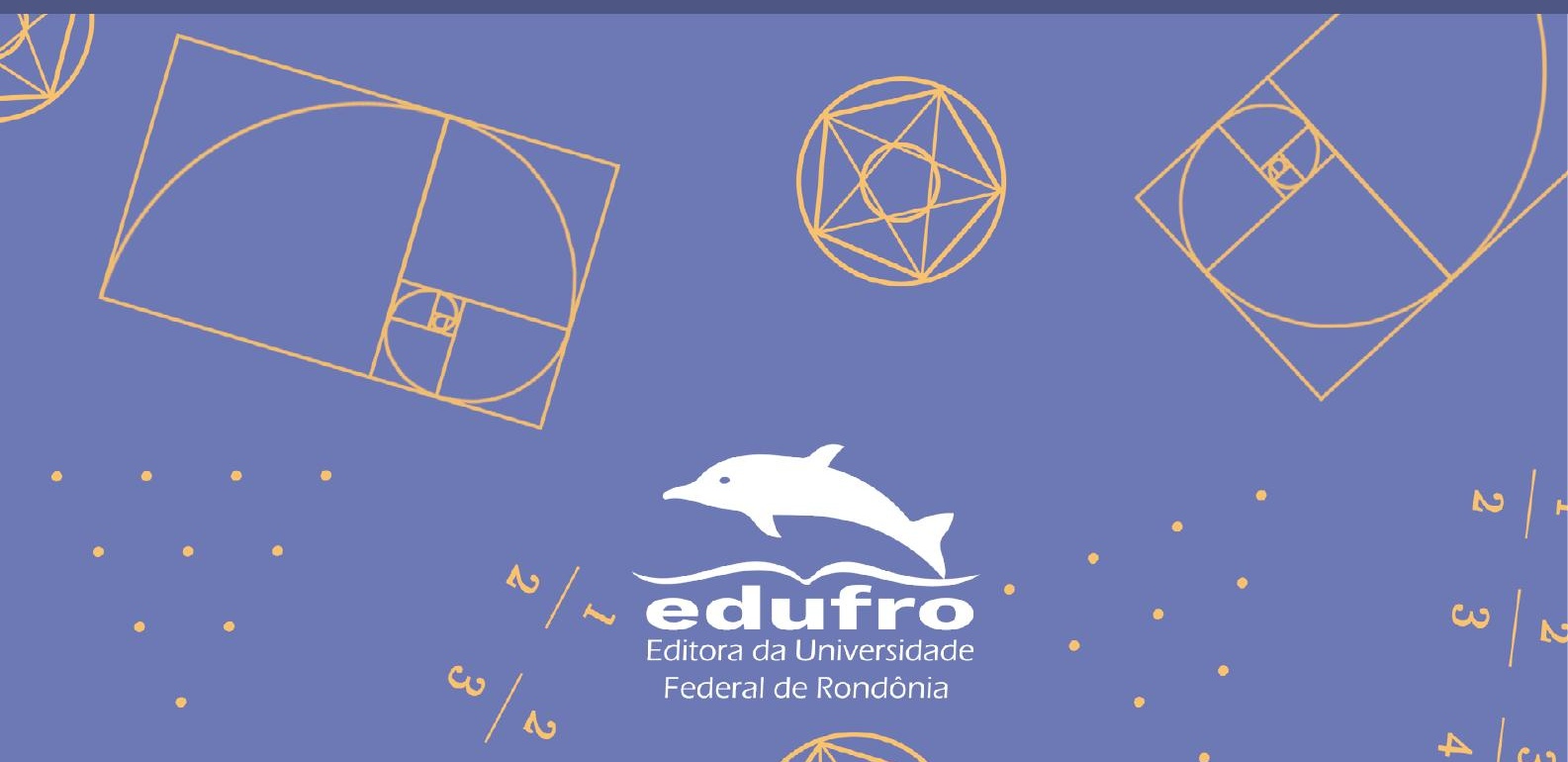


\section{PITÁGORAS PARA ALÉM DO TEOREMA}

Sérgio Candido de Gouveia Neto

Jean Sebastian Toillier

(Organizadores) 
Reitor Ari Miguel Teixeira Ott

Vice-Reitor José Juliano Cedaro

EDITORA DA UNIVERSIDADE FEDERAL DE RONDÔNIA

$\begin{array}{ll} & \text { CONSELHO EDITORIAL } \\ \text { Presidente } & \text { Lou-Ann Kleppa } \\ & \text { Ariana Boaventura Pereira } \\ \text { Carlos Alexandre Trubiliano } & \text { Eliane Gemaque Gomes Barros } \\ & \text { Gean Carla Silva Sganderla } \\ \text { Leandro Soares Moreira Dill } & \text { Márcio Secco } \\ & \text { Marli Lúcia Tonatto Zibetti } \\ & \text { Pedro Ivo Silveira Andretta } \\ & \text { Ricardo Gilson da Costa Silva } \\ & \text { Xênia de Castro Barbosa }\end{array}$

Editora Filiada
Edufro - Editora da Universidade Federal de Rondônia BR 364, Km 9,5
Campus Unir
76801-059 - Porto Velho - RO
Tel.: (69) 2182-2175
www.edufro.unir.br edufro@unir.br




\section{PITÁGORAS PARA ALÉM DO TEOREMA}

Sérgio Candido de Gouveia Neto

Jean Sebastian Toillier

(Organizadores)

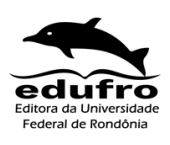

Editora da Universidade
Federal de Rondônia

Porto Velho - RO 
(C) 2020 by Sérgio Candido De Gouveia Neto, Jean Sebastian Toillier (Organizadores)

Esta obra é publicada sob a Licença Creative Commons Atribuição-Não

Comercial 4.0 Internacional.

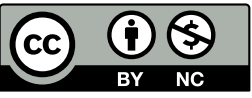

Capa:

Vitoria Gonçalves Morão

Revisão:

Dra. Jeane Mari Spera

Projeto gráfico:

Edufro - Editora da Universidade Federal de Rondônia

Diagramação:

Guilherme André de Campos

Impressão e acabamento:

Seike \& Monteiro Editora

Aprovado no Edital 02/2018/EDUFRO

Dados Internacionais de Catalogação na Publicação

Fundação Universidade Federal de Rondônia (UNIR)

Ficha Catalográfica elaborada pela Biblioteca Central da UNIR

F981 Fundação Universidade Federal de Rondônia.

Pitágoras para além do teorema / organização Sérgio Candido de Gouveia Neto, Jean Sebastian Toillier. - Porto Velho, RO: EDUFRO, 2020.

174 p.; il.

ISBN: 978-64-87539-36-2 (físico)

ISBN: 978-65-87539-29-4 (digital)

1. Matemática. 2. Arte. 3. Arquitetura. 4. História. I. Gouveia Neto, Sérgio Candido de. II. Toillier, Jean Sebastian. III. Fundação Universidade Federal de Rondônia.

CDU 51:72 


\section{Sumário}

7 PREFÁCIO

15 1. MÚSICA E MATEMÁTICA PITAGÓRICAS: SUAS INFLUÊNCIAS NO MUNDO MUSICAL

35 2. A INFLUÊNCIA DA ESCOLA PITAGÓRICA NA ARQUITETURA

71 3. UMA DIVINA PROPORÇÃO PARA OS PITAGÓRICOS

89 4. HISTÓRIAS SOBRE NÚMEROS PERFEITOS E AMIGÁVEIS

115 5. OS NÚMEROS FIGURADOS: DAS ORIGENS ÀS SUAS ATUAIS CONFIGURAÇÕES

145 6. OS PITAGÓRICOS EM LIVROS TEXTOS DA IDADE MODERNA

159 7. SOBRE MÉDIAS PITAGÓRICAS E MÉDIAS NOS LIVROS ESCOLARES DE MATEMÁTICA DO BRASIL (1900-1970)

173 SOBRE OS AUTORES 



\section{PREFÁCIO}

A "questão pitagórica" pode sem dúvida ser equiparada à "questão homérica”, a saber, um conjunto de indagações a respeito da vida e da obra desses personagens. Afinal, quem foi Pitágoras? Ele de fato existiu? Se sim, quais fatos tornaram a sua vida memorável? Teria ele sido um místico? Um cientista? Filósofo? Líder político? Charlatão? Talvez um pouco de cada uma dessas coisas, sem que possa ser definido de modo definitivo por uma única. Quais são os elementos fundamentais de sua doutrina? e como eles prevalecem na tradição posterior, com uma roupagem adequada aos seus próprios tempos? Assim, encontramo-nos defronte ao desafio de estabelecer a "extensão de nosso conhecimento ou nossa ignorância a respeito de Pitágoras e sua escola"1.

O nome de Pitágoras surge como um centro gravitacional em torno do qual orbitam interrogações. No equilíbrio desse sistema, algumas dúvidas possuem periodicidade maior, e as vemos passar por nossos olhos com maior frequência. Outras, mais distantes, é preciso esperar mais. Nessa reflexão temporal, podemos questionar o que nos permite classificar algo como pitagórico. Quais práticas e normas definem o pitagorismo? E, ainda, quando empregamos esse substantivo, quem estamos considerando como referencial? Seria o próprio sábio nascido em Samos, na região da Ásia Menor, em meados do século VI a.C., ou seus seguidores das colônias italianas? Do primeiro quase nada se sabe além de duas vidas escritas em período posterior, por Jâmblico (250 - cerca de 330) e Porfírio (233 - 309), entre outros relatos.

Foi na região da Magna Grécia que, depois de muito viajar e conhecer, Pitágoras se estabeleceu. A sua influência na organização social das colônias por onde passou foi decisiva, uma vez que nelas floresceram dois de seus maiores representantes ainda na Antiguidade: Árquitas de Tarento (cerca de 428 - cerca de 350 a.C.) e Filolau de Crotona (cerca de 470

\footnotetext{
${ }^{1}$ KAHN, C. Pitágoras e os Pitagóricos - uma breve história. Edições Loyola: São Paulo, Brasil, 2007, p. 17.
} 
- cerca de 390 a.C.). Em certa medida, Platão pode ser considerado um pitagórico. Em seus diálogos, elementos da doutrina pitagórica como a imortalidade da alma, o misticismo dos números, a dicotomia par e ímpar, a incomensurabilidade e alguma religiosidade dividem espaço com o mundo das ideias. O Mênon, o Timeu, o Filebo e a República são alguns poucos exemplos. A compreensão de diversas passagens matemáticas dos diálogos passa obrigatoriamente pelo entendimento da matemática pitagórica de Árquitas ${ }^{2}$, Filolau ${ }^{3}$ e outros dos quais falaremos a seguir.

Aristóteles faz menção na Metafísica (986a 22-26) aos "assim chamados pitagóricos" de elementos que lhe permitissem distinguir Pitágoras de seus discípulos. Mesmo para o Estagirita, que estava consideravelmente menos afastado no tempo e no espaço do espectro de Pitágoras, sua figura já havia sido envolvida pelas lendas.

Muitos e muitos nomes de pensadores seguidores dessa doutrina são de interesse para a história da matemática, como Hipócrates de Quios (cerca de 470 - cerca de 410 a.C.), Teodoro de Cirene (465 - 398 a.C., representado no diálogo Teeteto, de Platão) e Nicômaco de Gerasa (cerca de 60 - cerca de 120). Nessa esteira, encontraremos estratos fósseis do pitagorismo, seja no corpus de Euclides $^{5}$, como no de Arquimedes ${ }^{6}$. A tradição perdurou em Roma, como em Marco Túlio Cícero (106 - 43 a.C.), escritor e orador que nos conta em suas Discussões Tusculanas (V 3.9) ${ }^{7}$ uma bela história atribuída a Pitágoras. Reza a lenda que Pitágoras afirmou que a vida

${ }^{2}$ HUFFMAN, C. A. Archytas of Tarentum. Pythagorean, Philosopher and Mathematician King. Cambridge: CUP, 2005. 3 Philolaus of Croton. Pythagorean and Presocratic. Cambridge: CUP, 1993.

${ }^{4}$ ARISTÓTELES. Metafísica. V.III Texto grego com tradução ao lado. Tradução de Marcelo Perine. São Paulo: Edições Loyola, 2002, p. 27.

${ }^{5}$ EUCLIDES. Os Elementos. Tradução e introdução de Irineu Bicudo. São Paulo: Editora Unesp, 2009.

${ }^{6}$ HEATH, T. L. (Org.). The Works of Archimedes. Edited in modern notation with introductory chapters. Cambridge: CUP, 2010.

${ }^{7}$ MARINONE, N. (Org.). M. Tullio Cicerone: Opere Politiche e Filosofiche. V.II Torino: Unione Tipografico-Editrice Torinense, 1955, p. 444. 
se assemelha aos jogos disputados na Grécia. Pode-se identificar três tipos de pessoas: as que vieram para competir, em busca de glória e fama; as que vieram para fazer negócios, e tudo o que lhes interessa é comprar e vender; a última, e mais nobre, é a categoria do filósofo, que não persegue aplausos nem lucro, mas como expectador observa atentamente o que acontece e como acontece.

Uma "metamorfose ambulante" seria uma boa expressão para aludir ao pitagorismo através dos tempos. A tradição moderna esmerou-se em produzir uma bibliografia considerável em cada uma de suas características, a mística, a política e a científica. Diante dessa multiplicidade de referências, o leitor pode questionar se há a necessidade de mais um livro sobre o tema.A resposta retumbante é um "claro que sim!". Cada geração tem como desafio reorganizar essa tradição e expô-la à luz de seus princípios historiográficos, e respondendo às exigências de seu contexto social. Como no Grand Hotel de David Hilbert, com seus infinitos quartos ocupados por infinitos hóspedes, sempre é possível acomodar um novo convidado. No caso do hotel infinito, os hóspedes se mudam para o quarto adjacente, e o quarto liberado não é um novo quarto. A diferença aqui é a construção de um novo quarto, com móveis novos, cheirando a tinta fresca. Como citamos no início dessa introdução, cada geração tem que se haver com a extensão de seu conhecimento ou ignorância a respeito de Pitágoras e sua escola. E cada uma delas encontra respostas que são só suas. Sem mais delongas, o presente livro se apresenta como um conjunto de respostas dadas por quem se preocupa com o papel de Pitágoras no ensino da matemática e temas relacionados.

O primeiro artigo, de Carla Patrícia Ferreira dos Santos, nos leva a um passeio dos primórdios do estudo teórico dos sons. A teoria musical tem, como um de seus primeiros representantes, Aristóxeno (cerca de 375 - cerca de 300 a.C.), que escreveu um tratado sobre o tema. Apenas fragmentos de sua Elementa harmonica ${ }^{8}$ chegou até nós. Elementos de razões empregadas na música encontram-se também nos fragmentos de Árquitas, e um compêndio completo de música é atribuído a Euclides, a Sectio Cano-

\footnotetext{
${ }^{8}$ MACRAN, H. S. The Harmonics of Aristoxenus. Edited with translation notes, introduction and index of words. Oxford: Clarendon Press, 1902.
} 
$n i{ }^{9}$. Nessa obra, encontramos os intervalos fundamentais de que Carla nos fala; a quarta, a quinta e a oitava. Enquanto aritmética e geometria lidavam com objetos estáticos, a harmonia e a astronomia eram consideradas ciências matemáticas que lidavam com objetos em movimento, os astros celestes e o ar, respectivamente. $\mathrm{O}$ desenvolvimento da teoria musical foi longo, atraindo o interesse de Platão e Aristóteles. Os sucessivos aprimoramentos culminaram com a escala musical na Idade Média, até o desenvolvimento do logaritmo. Como auxílio didático, a autora nos fornece uma interpretação dos elementos musicais à luz de instrumentos modernos, como o violão e o piano.

No capítulo segundo, o texto de Islenis Carolina Botello Cuvides nos leva em uma viagem pela influência pitagórica na arquitetura. Antes que se pergunte como isso é possível, lembremos de um dos elementos fundamentais da doutrina pitagórica: a harmonia. A relação entre notas musicais passou a ser estudada a partir da modelagem fundamental de relações matemáticas. $\mathrm{O}$ interesse musical aproxima matemática e estética, e as proporções iniciais ultrapassam os limites do ouvido, encontrando justificativa na razão. O conúbio entre esses dois mundos, o do logos (razão, proporção, argumento, cálculo, relação, pensamento) e o do kalos (belo, admirável, elegante, nobre, honorável, justo) tornou-se um fim em si, subsumido nas demais atividades humanas. Desse modo, além da tradicional definição como a arte de moldar e realizar espaços agradáveis às necessidades dos homens, a arquitetura configura-se também como uma extensão dos princípios estabelecidos pela escola pitagórica. Remodelado inúmeras vezes ao longo dos séculos, os elementos que classificamos "pitagóricos" encontram-se de tal forma enraizados na cultura, que muitas vezes é preciso um estudo atento e disciplinado para trazê-los à tona. A influência da escola pitagórica na arquitetura os fazem transparecer no trabalho de Vitruvio, arquiteto do século I a.C., que conferiu estatuto disciplinar ao seu ofício, aproximando-a das artes liberais. $\mathrm{O}$ elemento motivador para o estudo da matemática desse

\footnotetext{
${ }^{9}$ BARBOSA, G. Euclides - Sectio canonis - apresentação e tradução. In: Revista Brasileira de História da Matemática. v.18, n. 36, Edição Especial - Traduções. Disponível em http:// www.rbhm.org.br/index.htm. Acesso em: 13 abr. 2019.
} 
capítulo encontra-se na polimatia gerada pela visão que Vitruvio tinha de sua arte, e a influência que exerceu no período do Renascimento.

$\mathrm{Na}$ sequência, o quarto artigo, de autoria de Renata Caterine Gambaro Cleto da Silva, traz a lume o problema da incomensurabilidade, porém, de uma perspectiva diferente. Sua linha de visão privilegia a tangência com a arte, a exemplo do capítulo que o precede. Como o seu nome já diz, Uma divina proporção para os pitagóricos trata de algo que representou um contrassenso à escola de Pitágoras, um entrave metafísico que repercutiu na matemática. De fato, são equivocadas as tentativas de se compreender os eventos que culminaram no que teria sido a primeira crise da matemática, levando em consideração apenas a matemática. Se os pitagóricos "dizem que as coisas são números", segundo Aristóteles na Metafísica $(1083 \mathrm{~b} 17)^{10}$, como se definiria aquilo que não se enquadra como número? Posto de outro modo: se tudo aquilo que é está em correspondência com os números e suas qualidades, o que dizer da diagonal do pentágono, ou do quadrado, que em sua relação com o lado da mesma figura mostra-se inefável? Deveríamos simplesmente negar a sua existência? Mas como isso seria possível, uma vez que o que não existe não pode sequer ser pensado, dito ou representado? Como pano de fundo, temos a tese de Parmênides ${ }^{11}$, filósofo de Eléia - colônia da Magna Grécia - ativo na primeira metade do século $\mathrm{V}$ a.C.: o que é não pode não ser. Seu discípulo, Zenão, levaria ao extremo as consequências desse princípio lógico, dando origem aos famosos paradoxos a respeito do movimento, que por séculos atormentaram filósofos e matemáticos. De modo semelhante, pelas mãos dos pitagóricos, um ente geométrico penetrou no mundo da comensurabilidade e da razão mesma, dando origem a um evento decisivo que exigiu dos gregos uma revisão de suas bases do pensamento. Designada pelos gregos com o termo alogon, literalmente sem logos, e por extensão inexprimível, incalculável, absurdo, a anomalia é conhecida por nós como irracional. Durante milênios a huma-

\footnotetext{
${ }^{10}$ ARISTÓTELES, Metafísica. V.III Texto grego com tradução ao lado. Tradução de Marcelo Perine. São Paulo: Edições Loyola, 2002, p. 633.

${ }^{11}$ PARMENIDES. Da Natureza. Tradução, notas e comentários de José Trindade dos Santos. São Paulo: Edições Loyola, 2002.
} 
nidade vem atribuindo aos deuses o que ela é incapaz de compreender. Abrigando-se em tal recurso, o matemático italiano Luca Pacioli (1445 -1517) justificou a chamada "razão áurea" como algo divino. Uma antiga razão geométrica destituída de razão numérica, encontrada em Euclides, e em monumentos e obras de arte ao longo da história, como nos mostra o texto de Renata.

O quarto capítulo, Histórias sobre números perfeitos e amigáveis, de Jean Sebastian Toillier, toma como princípio o misticismo aritmético dos pitagóricos, para conduzir uma narrativa do desenvolvimento do estudo dos números. Os números chamados perfeitos e amigáveis estão assim no núcleo de uma discussão onde matemática e mito se fundem. Mas, afinal, quando foi que essas formas de pensamento se divorciaram? E o que determina tal afastamento? $\mathrm{O}$ poder dos mitos reside em sua capacidade educativa aliada ao poder simbólico da linguagem metafórica. $\mathrm{Na}$ etimologia da palavra grega mythos estão os significados palavra, discurso, estória, entre outros que estão presentes também no logos. "Mitos não são mentiras; e também não são histórias neutras. São modelos imaginativos, redes de símbolos poderosos que sugerem maneiras particulares de interpretarmos o mundo, moldando o seu significado"12. Os números e as figuras que são o objeto de estudo da matemática deram vida ao cosmo pitagórico. Desse modo, na aurora do pensamento grego, os entes matemáticos constituíram a narrativa do real. A mesma civilização grega que entrelaçou o mito e a razão com o cordão umbilical de sua linguagem decidiu em algum momento que eles tinham que ser separados. O processo de afastamento foi lento e gradativo, e recentemente aprofundado pelo século das luzes. Já antes disso, os números passaram então a ser estudados em si e por si, sem os seus significados existenciais, ainda na Antiguidade. Podemos pensar que parte do trabalho de Euclides foi "exorcizar" a metafísica de sua ciência. Uma ciência dos números foi erigida unicamente a partir de suas propriedades e relações numéricas. Contudo, uma essência pitagórica manteve-se. Os princípios da chamada teoria dos números: o par e o ímpar, os primos e os compostos,

${ }^{12}$ MIDGLEY,M.A presença dos mitos em nossas vidas. São Paulo: Editora Unesp, 2014,p. 21. 
os quadrados e as potências, e a comensurabilidade, permaneceram sendo explorados e apurados ao longo dos séculos. Muitos nomes da História da Matemática aparecem na relação que o autor do capítulo tece, ao lado de resultados impressionantes. Uma parte importante dessa história é a literatura epistolar da matemática que entra em cena, os registros de cartas como documentos vivos da pesquisa.

O quinto capítulo, Os números figurados: das origens à suas atuais configuraçôes, de Débora Vieira de Souza, representa um complemento ao anterior. $\mathrm{O}$ seu tratamento também considera a questão da mitologia dos números no pitagorismo, porém sob as possibilidades de configuração geométrica, e um passo em direção à consolidação do logos. Os números e as figuras representam um afastamento das cosmogonias dos primeiros pensadores. Tales de Mileto teria dito que tudo é água, algo compreensível para uma mente astuta que observa o efeito das chuvas sobre o solo ou a rica vida marinha do mediterrâneo. O seu diferencial está na identificação de um elemento físico como origem das coisas. Seu discípulo Anaximandro dá um importante passo em direção à abstração ao abrir mão dos elementos físicos para identificar como princípio do devir cósmico o apeiron, isto é, um princípio "sem limite". Tudo aquilo que é definido, limitado, deve ter pertencido a um estado anterior em que não obedecia a tais atributos materiais. Anaxímenes, por sua vez, identifica o princípio no ar. Para esse filósofo, todas as coisas estão envolvidas pelo ar, e o processo de respiração é o que permite a vida aos homens. Com Pitágoras, não é um elemento físico, mas entes matemáticos como números e formas que explicam a natureza e por que as coisas são como são. Às qualidades dos números, como par e ímpar, são acrescentadas outras, como quadrado e triangular, e ainda masculino e feminino. As regularidades dos números são acompanhadas por regularidades geométricas. Segundo a perspectiva da autora, a construção dos números figurados, apresentados em seu capítulo, auxilia no ensino da matemática, como mostra o seu estudo.

Os pitagóricos em livros textos da idade moderna, de Arlete de Jesus Brito, reflete sobre a transmissão do pitagorismo nos séculos XVI e XVII. A filosofia grega teve boa parte absorvida pela religião católica e, depois, 
pelo protestantismo. Por essa via, os princípios do pitagorismo passaram a ser disseminados na educação escolar. Em meio às disciplinas ensinadas, como o grego, a lógica, a ética e as ciências matemáticas, os livros didáticos permitiram que ensinamentos considerados esotéricos, por gerações, pudessem ser propagados. A seita se expandiu para muito além de onde seus idealizadores jamais sonharam, e por meios que eles sequer podiam imaginar. $\mathrm{O}$ pitagorismo, assim, tornou-se parte de um currículo, e encontrou nas escolas uma versão moderna de seu templo.

Por fim, Sobre médias pitagóricas e médias nos livros de matemática escolares do Brasil, Sérgio Candido de Gouveia Neto analisa, como o seu título diz, a aparição do pitagorismo nos livros escolares. Novamente, o capítulo serve como uma continuação de seu anterior, respeitado o óbvio salto temporal. A presença e a ausência do pitagorismo nos livros escolares têm variado ao longo dos anos. Tábuas pitagóricas, números figurados, máximo divisor comum, mínimo múltiplo comum, números primos e amigáveis eram diversificados ao sabor das diferentes propostas curriculares. As mudanças, no que diz respeito às definições de médias, é um assunto que chama a atenção do educador. Em comparação com as médias pesquisadas por Nicômaco de Gerasa, os livros didáticos trazem alterações que respondem aos interesses do avanço da ciência em nosso país.

Como o leitor pode perceber, o livro que ele tem em mãos cobre aspectos artísticos e didáticos, científicos e filosóficos, tendo sua utilidade assegurada tanto ao interessado em cultura geral e no pitagorismo, como ao educador que aqui encontrará direcionamentos para lidar com Pitágoras e os pitagóricos com muito mais propriedade em suas aulas.

Gustavo Barbosa 


\section{MÚSICA E MATEMÁTICA PITAGÓRICAS: SUAS INFLUÊNCIAS NO MUNDO MUSICAL}

Carla Patrícia Ferreira dos Santos

"A música é um exercício inconsciente de cálculos."

Leibniz

\section{Introdução}

O objetivo deste capítulo é levar o leitor a passear desde a Grécia, com o desenvolvimento dos estudos sobre a música e o som, até as influências deixadas pelos Pitagóricos na Antiguidade e no mundo que nos rodeia hoje. Para tal viagem, serão necessários alguns conhecimentos históricos e a distinção de termos musicais utilizados pelos gregos e os que a música utiliza atualmente. Para isso, iniciaremos discorrendo um pouco sobre os estudos realizados por Pitágoras e o Monocórdio e os Pitagóricos na Antiguidade, deixando em aberto ao leitor acreditar ou não nesses fatos, dado que nunca foi encontrado por nenhum historiador tal instrumento, mas as teorias Matemáticas, ditas desenvolvidas por esse grupo, permeiam o mundo matemático e musical de forma a resolver e demonstrar os seus resultados.

Segundo Zaleski (2013), os Pitagóricos tinham como base filosófica que tudo no mundo poderia ser explicado por meio dos números e que, dentro desse conhecimento, a Arte também poderia ser explicada por intermédio da Matemática. Nesse modo de classificar o conhecimento, a música, que é hoje conhecida como uma forma de Arte, poderia ser assim explicada também. Faremos, então, a primeira distinção entre a música como arte na Antiguidade e atualmente.

No século VI a.C., na Grécia antiga, a música não era considerada como uma disciplina participante do quadro das belas artes; isso mudaria somente na Idade Moderna, pois até então era considerada uma das sete 
Artes Liberais, pertencendo ao Quadrivium (Música ${ }^{1}$, Aritmética, Geometria e Astronomia). Além do Quadrivium, havia o Trivium (Gramática, Lógica e Retórica). Mas há controvérsias se a música pertencia realmente ao Quadrivium, já que, de acordo com Cicero, ora a música se relacionava com as matemáticas, ora com a gramática (DE ORATORE, I, 187 e III, 127, apud GILSON,1995, p.205 apud BRITO, 1999, p. 107)². Outra questão em que devemos atentar é que disso decorre que a música não era vista como uma arte servil, ou seja, algo que deveria ter destreza e habilidades para ser desenvolvida, como, por exemplo, a pintura; portanto, a música era algo teórico e não prático.

Nesse momento da história grega, foram perceptíveis as influências que a filosofia platônica exercia sobre a polis. Essa filosofia dividia o mundo de duas formas: um mundo sensível (concreto) e um mundo inteligível (mundo das ideias, raciocínio). Nesse contexto, esperava-se de um filósofo/matemático elevar o pensamento de uma mera opinião a um patamar científico ${ }^{3}$ que seria o caminho para conhecer a verdade. Os gregos estavam preocupados em entender o "porquê" das coisas, e não o "como"; acreditavam que a música exercia um poder moral sobre o homem, por isso, inclusive, os filósofos Platão e Aristóteles defendiam o seu ensinamento:

Os gregos acreditavam que a música exercia um poder moral e ético sobre o homem. Filósofos como Platão (428 a.C-348 a.C.) e Aristóteles (367 a.C.-347 a.C.) defendiam o seu ensinamento na formação do cidadão livre. (BROMBERG; SAITO, 2017, p.35)

Nesse sentido, a música não só elevaria o espírito a uma experiência em que fosse possível se esquecer das coisas terrenas, mas elevaria a alma à essência das verdades eternas do mundo inteligível; e a ponte entre um mundo e outro, acreditava-se, seria feita pelos números que estariam dire-

\footnotetext{
${ }^{1}$ A palavra música em letra maiúscula significa a música como uma disciplina de estudo, a qual abrange todas as vertentes de estudo dentro desse tema.

${ }^{2}$ GILSON, E. A filosofia na Idade Média. São Paulo: Editora Martins Fontes, -195.

${ }^{3}$ Esta denominação "patamar científico" é atual e não própria da época, e vem no sentido de: conjecturar ideéis e pensamentos.
} 
tamente envolvidos com a harmonia, que, para os antigos gregos, poderia significar movimento, ordem, beleza, conformidade ou, ainda, o que tem tendência a ser afinado (agradável ao ouvido). Essa ideia de o número explicar a música, ou seja, de o número figurar como o mundo inteligível e a música representar o mundo sensível, era fortemente defendida por Platão, opinião da qual Aristóteles discordou posteriormente, pelo fato de separar o número do mundo sensível. No entanto, havia uma concordância entre esses dois filósofos quando se tratava da música como uma ferramenta guia para os homens livres ${ }^{4}$. Nesse contexto histórico, tocar um instrumento era visto como impróprio a um homem livre.

Dentre os filósofos matemáticos dessa época, daremos maior importância, como proposto neste livro, a Pitágoras e aos Pitagóricos. Acredita-se que Pitágoras nasceu na Ilha de Samos, entre os anos de 570 - 500 a.C., e que todas as práticas pitagóricas, dentre elas crer em um lado místico das coisas, possivelmente fomentou a curiosidade desse filósofo por desvendar e entender o porquê de um som ser "harmonioso" ao ouvido, o que fez com que desenvolvesse um instrumento com o qual pudesse verificar suas conjecturas matemáticas.

\section{A música por Pitágoras e suas implicações}

$\mathrm{Na}$ Antiguidade, a música também era conhecida por harmonia e foi classificada segundo duas tradições teóricas: a Pitagórica e a Aristoxênica 5 .

A denominação "médias harmônicas" teria sido atribuída por Arquitas (428 a.C-347 a.C) ou por Filolaus (470 a.C-385 a.C) no século IV; antes eram chamadas de média subcontrária (BOYER,1996 apud ABDOUNOUR, 1999, p.8)6. Para Pitágoras de Samos, a música poderia ser explicada por meio de tais médias que associavam os intervalos musicais às razões de números inteiros, as quais seriam 1:2, 2:3, 3:4 e 8:9. Essas razões produzi-

\footnotetext{
${ }^{4}$ Eram considerados homens livres os cidadãos da polis, exceto mulheres e escravos.

${ }^{5}$ Vide Bromberg e Saito (2017)

${ }^{6}$ BOYER, C.B. História da Matemática. São Paulo: Editora Edgard Blücher, 1996
} 
riam, em um instrumento conhecido como monocórdio, sons "consonantes" e "dissonantes".

A priori, precisamos esclarecer que os Pitagóricos nunca utilizaram os termos "consonantes" e "dissonantes", os quais surgiram somente na Idade Média. Para os gregos, sons consonantes eram aqueles que correspondiam às razões de intervalos, e hoje consonância (do latim consonare, que significa soar junto) vem a agregar ideias, como: harmonia, acorde ${ }^{7}$. Já dissonante é o contrário de um som consonante.

Aprofundando mais a doutrina pitagórica, encontramos a crença de que tudo teria sido formado a partir da "unidade única", ou seja, tudo aconteceria (surgiria) a partir dela, e sua relação para com tudo seria estabelecida por meio de proporções. O sentido dessas proporções se tornará mais claro ao longo do capítulo e das definições acerca dos termos musicais.

Segundo Bromberg e Saito (2017), a música é formada por um conjunto de sons produzidos sucessivamente e silêncio, tudo isso organizado ao longo de intervalos de tempo. Nesse sentido, os compositores Lulu Santos e Nelson Motta foram enfáticos ao afirmar na canção "Certas coisas", que nós "somos feitos de silêncio e som" (SANTOS; MOTTA, 1984), então seríamos nós feitos de música? Platão, em Timeu, afirma:

Quanto à voz e à audição, o raciocínio é mais uma vez o mesmo: os deuses concederam-no-las pelas mesmas razões e com os mesmos fins. $\mathrm{Na}$ verdade, foi com o mesmo fim que nos foi atribuída a fala, que tem um papel fundamental na nossa interação; tudo quanto é útil à voz no contexto da música, isso nos foi dado por causa da harmonia da audição. Com efeito, para aquele que se relaciona com as Musas com o intelecto, a harmonia, feita de movimentos congéneres das órbitas da nossa alma, não é um instrumento para um prazer irracional - como agora se julga ser - mas, em virtude de as órbitas da nossa alma serem desprovidas de harmonia desde a geração, aquela foi concedida pelas Musas como aliado da alma para a pôr em ordem e em concordância. (TIMEU, 47C, 2011, p. 128).

\footnotetext{
${ }^{7}$ Acorde: Conjunto de três ou mais notas que se ouve como se estivessem soando simultaneamente. Disponível em: https://pt.wikipedia.org/wiki/Acorde. Acesso em 19/02/18.
} 
As musas citadas por Platão são: Calliope, Clío, Euterpe, Terpsíchore, Erato, Melpomene, Thalia, Polyhyminia e Urânia, as quais seriam as filhas de Zeus, e cada uma, respectivamente, influenciava, segundo Oliveira (2010, p.13), a Poesia Épica, a História, a Arte de tocar flauta, a Dança, a Poesia Lírica, a Comédia, Hinos, Pantomima e Astronomia. Considerando a citação feita por Platão, a audição humana, a voz e o raciocínio teriam sido criados pelos deuses para que, por meio da música, deixássemos de ser irracionais e passássemos a ser criaturas harmoniosas com nossa alma, isto é, que usássemos o intelecto, a inteligência. Sobre a inteligência, Lysis (490 a. C.- 560 a. C), discípulo de Pitágoras, teria escrito os seguintes versos: [...] "Sobre o teu corpo reine e brilhe a Inteligência/ Para que, te ascendendo ao Éter fulgurante/ Mesmo entre os Imortais consigas ser um deus”. (SANTOS, 2000, p.236).

O éter, para os Pitagóricos, seria a origem de todas as coisas e, dessa forma, mais uma vez, agora por meio de Lysis, seria preciso inteligência, que teria o sentido de conhecimento para atingir um patamar superior (mundo inteligível), aqui figurado como um deus.

Historicamente, ainda houve um momento em que a música era utilizada para explicar o universo e o movimento dos astros e como se fosse um "se e somente se" matemático; a quantidade de planetas descobertos até então chegou a influenciar, da idade Antiga até o Renascimento, a quantidade de notas musicais que seriam adotadas como base da música europeia, ou seja, uma escala ${ }^{8}$ musical de 7 notas. Eram conhecidos 7 planetas, baseados na teoria geocêntrica de Aristóteles: Lua, Mercúrio, Vênus, Sol, Marte, Júpiter e Saturno. Vale ressaltar que, em outros continentes e países, há um conceito de escala diferente do europeu e, portanto, a quantidade de notas musicais bases pode ser diferente; por exemplo, a música hindu possui 22 notas bases para suas escalas. A harmonia celeste teria influenciado Pitágoras em seu conceito de Harmonia, a princípio, com os tetracordes (Dó, Fá, Sol, Dó) e, após, com a escala de sete tons.

\footnotetext{
${ }^{8}$ Escalas musicais são sequências ordenadas de notas. Por exemplo: dó, ré, mi, fá, sol, lá, si, dó, repetindo esse ciclo. Disponível em http://www.descomplicandoamusica.com/escalas-musicais/. Acesso em 18/02/18.
} 
É importante também ressaltar que alguns filósofos da época possuíam métodos diferentes de Pitágoras para obtenção das escalas musicais. Segundo Abdounour (1999), Pitágoras teria empregado um instrumento chamado monocórdio e utilizado a quinta como base para encontrar outros sons consonantes. Por intermédio dos estudos de Pitágoras, Arquitas construiu uma escala baseada nas médias harmônicas e aritméticas daquelas encontradas anteriormente; já Erastóstenes (284 a.C-202 a.C.), baseou-se nos estudos de Arestóxeno (360 a.C-300 a.C.) para obter os intervalos por meio do cálculo de razões.

Sabe-se, hoje, que os três elementos musicais principais de uma música são: melodia, harmonia e ritmo. Pereira (2013) disserta que melodia é o estudo dos sons tocados separadamente em sequência. Um solo de um instrumento de corda ou um canto podem ser exemplos de melodia. A melodia é o estudo das combinações dos sons tocados simultaneamente. Quando tocadas duas ou mais notas musicais ao mesmo tempo, constitui-se uma harmonia. Já o ritmo é a parte da música responsável pela duração de cada nota. Descartes definiria a harmonia como natural ao ouvido humano, pois “tal característica cansaria menos o ouvido, já que, na onda resultante, o número de pulsos a serem percebidos diminui em função das coincidências" (ABDONOUR, 1999, p.6), ou seja, nossos ouvidos seriam naturalmente voltados para sons harmoniosos.

O ritmo, para Arestóxeno de Tarento (360 a.C- 300 a.C), constituía uma ambiguidade: aquilo que se move e aquilo que não se move seria um sistema organizado de duração, e essa definição é facilmente percebida quando se ouve uma música. Bromberg e Saito (2017) relatam em seu livro que podemos desconhecer o termo técnico ritmo, porém podemos senti-lo de forma "natural", desde que entendamos de duração de tempo. A respeito de ritmo, podemos observar também que a fala, a forma de pronunciar a palavra, pode influenciar no ritmo em relação à produção musical de cada sociedade. Segundo Platão (BROMBERG; SAITO, 2017), o ritmo era o tratamento dado às sequências silábicas. Da mesma forma, Aristóteles acreditava que ritmo era o número da forma da palavra, portanto, um determinado sotaque pode influenciar a duração de um acorde ou as modulações 
de uma música. Mas o que são música e som? Você já parou para refletir sobre essa simples pergunta?

A música, para Pitágoras, era os sons consonantes que poderiam ser explicados por meio de médias harmônicas e médias aritméticas. Para Nicômaco (I,3 I apud BRITO, 1999), a música era o estudo de números relativos. Já para Agostinho (354-430), era “[...] a arte do bem 'modular', isto é, do bem 'medir o som' considerando-se a altura e a duração (e a sua relação com a harmônica e a rítmica), bem como ideia de movimento.” (BROMBERG; SAITO, 2017, p.67). Para Cassiodoro (490 -581 d.C), "a música é a disciplina que expressa os números, os quais intervêm no som" (Etim, II, 24, e III, Prefácio apud BRITO, p.104, 1999)9 , ou ainda "música é a perícia na modulação existente no som e no canto" (ETIM, III, 15 apud BRITO, 1999, p.104 )10. Podemos também citar Boécio (480-524), que dividiu sua definição de música em duas: Música Mundana e Música Humana (BROMBERG; SAITO, 2017).

Tratava-se como música mundana a "música do universo", que seria o movimento dos planetas e funcionamento dos corpos celestes; como música bumana, o equilíbrio entre os sons graves e agudos de modo que, quando consonantes, ligavam o racional e o irracional à alma; seria aquilo que une os elementos do corpo. Tratando-se da definição de som, Platão, em Timeu, afirmou que "o som era uma pancada infligida pelo ar e transmitida pelos ouvidos, cérebro e sangue até a alma" (BRITO, 1999, p.66). Diante de todas as definições para música e som, podemos perceber que se tratava realmente de uma ferramenta para elevar o ser material ao mundo das ideias e perceptível pelos seres humanos.

Dadas as devidas apresentações acerca de alguns termos musicais, retornamos a Pitágoras, pois tudo indicia que ele seria estudioso da harmonia musical (a palavra harmonia aqui se refere à definição atual); para isso realizou um experimento em um instrumento chamado monocórdio e lançou mãos das razões harmônicas para explicar por que algo é harmônico.

\footnotetext{
${ }^{9}$ ISIDORO. Etimologias. v I e II. Madrid: BAC, 1983.

${ }^{10}$ ISIDORO.Etymologiarvm sive originvn. Oxford: Oxford University Press, 1911.
} 
Podemos diferenciar o sentido de "experimento" realizado na Antiguidade por Pitágoras e o contexto de experimento na Idade Média, pois “[...] tais como a escultura e a arquitetura foi principalmente através do sentido da visão que as proporções puderam ser mais claramente evidenciadas. Na música a noção de proporção podia ser percebida 'auditivamente" (BROMBERG; SAITO, 2017, p.87); portanto, na Antiguidade os matemáticos se utilizavam do mundo sensível para suas conjecturas matemáticas, o que mudaria na Idade Média, pois os matemáticos, que essencialmente dissertavam acerca dos elementos musicais, diferentemente de Pitágoras, já não estavam totalmente interessados na produção sonora, mas sim nos objetos abstratos do mundo matemático.

Quando se trata da música como uma disciplina de estudo separada das belas artes, "os Pitagóricos foram os únicos até Aristóteles a fundamentar cientificamente a música” (ABDOUNOUR, 1999, p.4). Essa fundamentação se iniciou por Pitágoras que, possivelmente, inventou o monocórdio. Acredita-se que era um instrumento composto por uma corda estendida entre dois cavaletes fixos, com um terceiro cavalete móvel colocado sobre a corda para dividi-la (assemelha-se, de certo modo, a um violão sem caixa acústica aberta e, utilizando um capotraste ${ }^{11}$, dividia-se a corda da maneira que fosse necessária).

No início de seus experimentos, evidenciaram-se as relações entre o comprimento da corda e a altura do som emitido. Isso remeteu ao conceito de grave e agudo. $\mathrm{Na}$ Antiguidade, agudo era definido por um som que "cortava" ou "picava"; grave, um som que "esmagava" ou "pressionava" (BROMBERG; SAITO, 2017). O segundo passo do experimento contemplou a relação entre o comprimento da corda e o tom musical emitido por ela. Pitágoras observou que, ao pressionar a corda no ponto que equivalia a 3/4 da corda estendida, o tom por ela produzido era uma quarta acima do som da corda inteira; de mesmo modo, ao pressionar a corda no ponto

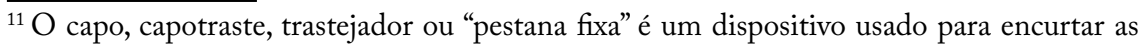
cordas e assim tornar as notas mais agudas, em um instrumento de cordas como guitarra, violão, bandolim ou banjo. Disponível em https://pt.wikipedia.org/wiki/Capo. Acesso em 19/02/18.
} 
$2 / 3$, ouvia-se uma quinta acima, e $1 / 2$, ouvia-se a oitava do som original. Mas o que é oitava, quinta, tom? Pois bem, suponha que o comprimento da corda seja de medida c:

- Tônica (tom base da escala) - razão $\frac{1}{1}$, tamanho da corda c;

- Oitava - razão $\frac{1}{2}$, tamanho da corda $\frac{1 c}{2}$;

- Quinta - razão $\frac{2}{3}$, tamanho da corda $\frac{2 c}{3}$;

- Quarta - razão $\frac{3}{4}$, tamanho da corda $\frac{3 c}{4}$.

A partir dessas constatações, Pitágoras verificou quais intervalos seriam consonantes (harmoniosos, como um acorde de violão) e estas ficaram conhecidas como Consonância Pitagórica. Agora, note que os únicos números utilizados por Pitágoras na sua definição foram 1,2, 3 e 4, o que, para os pitagóricos, fazia todo o sentido segundo sua filosofia, pois para eles os números mencionados geravam a perfeição; dentre eles, o número quatro é o que mais se destaca, por ser o primeiro quadrado par, a origem de todo o universo e todo o mundo material, segundo suas crenças.

Se você não conseguiu imaginar como era o Monocórdio feito por Pitágoras e seu experimento, observe as figuras 1 e 2.

Figura 1 - Exemplo de Monocórdio

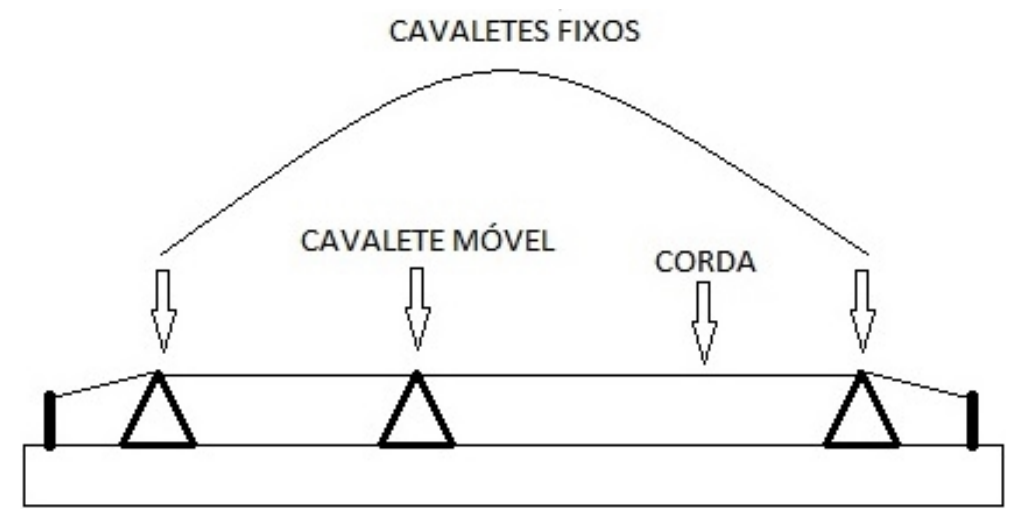

Fonte: Elaborado pela autora 
Figura 2 - As divisões do Monocórdio no violão

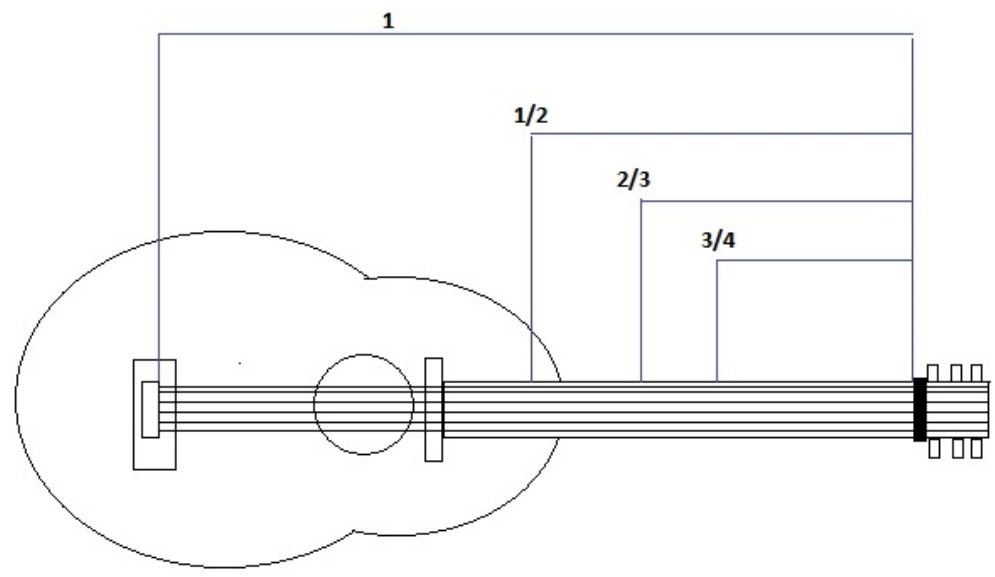

Fonte: Elaborado pela autora.

Ainda existiu uma mística envolvendo a história dos martelos de Pitágoras:

Segundo uma lenda contada por Guido D'Arezzo, no tratado sobre música intitulado Micrologus, Pitágoras, ao ouvir os diferentes sons produzidos pelas batidas dos martelos numa oficina de ferreiro, percebeu que estes propiciavam uma sensação agradável e tinham uma harmonia entre si. Ele também teria notado que os valores dos sons poderiam ser expressos por relações numéricas (proporções) e que, para sua surpresa, os martelos que produziam os sons mais agradáveis (consonantes) pesavam 12, 9, 8 e 6 unidades de massa. (PEREIRA, 2013, p.20).

Em Brito (1999), podemos observar que os números 6, 8, 9 e 12 são relacionados com a escala pitagórica pelo fato de poderem ser obtidos na teoria de tom, oitava, quinta e quarta e por suas propriedades diante dos conceitos matemáticos de proporção, média aritmética12 e média harmônica13, ou seja, tomando por denominador o número inteiro 12,

\footnotetext{
$\overline{{ }^{12} \text { Média Aritmética }}=\mathrm{a}+\mathrm{b} / 2$

${ }^{13}$ Média Harmônica $=2 \mathrm{a} \cdot \mathrm{b} /(\mathrm{a}+\mathrm{b})$
} 
podemos obter um tom, uma oitava, uma quinta e uma quarta, a partir de frações equivalentes:

\section{$\frac{12}{12}, \frac{6}{12}, \frac{8}{12}, \frac{9}{12}$}

Agora note que:

- A média Aritmética entre 6 e 12 é 9;

- A média Harmônica entre 6 e 12 é 8 ;

- Os números 6, 8, 9 e 12 formam uma proporção: $\frac{6}{8}=\frac{9}{12}$.

Temos, ainda, que as notas são diferenciadas pelos intervalos de oitavas e que elas apresentam certa semelhança em seus sons, apenas diferenciando em um Dó, por exemplo, mais agudo, ou Dó mais grave. Abdonour (1999) afirma que pode ser definida uma Classe de Equivalência sobre a escala pitagórica e, quando falamos em classe de equivalência, nos referimos matematicamente ao conceito definido por meio de uma relação de equivalência: "Duas notas são equivalentes se diferirem em intervalo por um número inteiro de oitavas" (ABDONOUR, 1999, p. 9). Devemos provar as seguintes propriedades: Reflexiva, Simétrica e Transitiva. Traduzindo o "enunciado", matematicamente, temos:

Se duas notas musicais $A$ e $B$ são semelhantes, então: $A=B \leftrightarrow B=\left(\frac{1}{2}\right)^{n} A, n \in \mathbb{Z}$

- Reflexiva: Seja A uma nota musical, se $A \sim A$ :

- $A \sim A \rightarrow A=\left(\frac{1}{2}\right)^{n} A, n \in \mathbb{Z}$. Tomando $n=0$ temos que: $A=A \rightarrow A \sim A$.

- Simétrica: Sejam $A$ e $B$ duas notas musicais semelhantes se $A \sim B$ , então $B \sim A$ :

$$
A \sim B \rightarrow B=\left(\frac{1}{2}\right)^{n} A \rightarrow A=\left(\frac{1}{2}\right)^{-n} B, \operatorname{como}(-n) \in \mathbb{Z} \text {. Logo, }
$$

temos que $B \sim A$. 
- Transitiva: Sejam $A, B, C$ notas musicais semelhantes se $A \sim B$ e $B \sim C$, então $A \sim C$ :

- $A \sim B \rightarrow B=\left(\frac{1}{2}\right)^{n} A$

$$
B \sim C \rightarrow C=\left(\frac{1}{2}\right)^{m} B, n, m \in \mathbb{Z}
$$

- Por (1) e (2), temos:

$$
C=\left(\frac{1}{2}\right)^{n} \cdot\left(\frac{1}{2}\right)^{m} A \rightarrow C=\left(\frac{1}{2}\right)^{n+m} A,(n+m)=p, p \in \mathbb{Z} .
$$

- Assim:

$$
C=\left(\frac{1}{2}\right)^{p} A \rightarrow A \sim C
$$

Logo, pela propriedade reflexiva, simétrica e transitiva, temos que o conjunto de notas equivalentes é uma Relação de Equivalência e, portanto, faz todo o sentido enxergarmos a distribuição das notas na escala Pitagórica como uma Classe de equivalência. Veja a mesma afirmação de maneira mais prática, apresentada por Pereira (2013), por meio de sequências:

Fracionando em pedaços ainda menores uma corda de comprimento c.

- Oitavas: $\frac{c}{2}, \frac{c}{4}, \frac{c}{8} \ldots,\left(\frac{1}{2}\right)^{n} \cdot c$;

- Quartas: $\frac{3 c}{4}, \frac{3 c}{8}, \frac{c c}{16} \ldots,\left(\frac{1}{2}\right)^{n} \cdot \frac{3 c}{4}$;

- Quintas: $\frac{2 c}{3}, \frac{c}{3}, \frac{c}{6} \ldots,\left(\frac{1}{2}\right)^{n} \cdot \frac{2 c}{3}$.

Dessa forma, é fácil encontrar a fração que representaria uma quarta mais aguda, ou seja, por exemplo, 3 oitavas acima:

$$
\left(\frac{1}{2}\right)^{3} \cdot \frac{3 c}{4}=\frac{1}{8} \cdot \frac{3 c}{4}=\frac{3 c}{32}
$$

Agora, caro leitor, se você ainda não acredita que todos esses cálculos matemáticos e experimentos realizados por Pitágoras podem se tornar uma 
harmonia (sons consonantes), convido-o a verificar pelo menos uma nota, como o pensador de Samos fez há mais de 2500 anos:

- Pegue um violão, escolha uma corda qualquer dele; toque-a sozinha e ouça o som; se possível, grave em algum dispositivo para comparar com o novo som que irá obter;

- Agora coloque um capotraste ou aperte a mesma corda na $12^{\text {a }}$ casa e toque-a novamente.

- A $12^{\text {a }}$ casa do violão é a metade do comprimento da corda e, portanto, você ouvirá o som de uma oitava, a partir do tom que escolheu;

- Se puder ouvir os dois sons ao mesmo tempo, perceberá a harmonia que há entre os dois sons.

Desse mesmo princípio, do qual Pitágoras obteve os Tetracordes, foi possível originar as outras notas musicais como conhecemos hoje.

\section{A escala pitagórica}

Sabe-se que a escala musical possui apenas quatro sons baseados nos estudos de Pitágoras, que são DÓ, FÁ, SOL, DÓ (vide Tabela 1). A partir dessas quatro notas, foi possível obter a Escala Diatônica de DÓ. Essa escala possui 7 notas, incluindo a oitava, que a transforma numa sequência de 8 notas musicais: DÓ, RÉ, MI, FÁ, SOL, LÁ, SI, DÓ. O número anexo à nota significa a oitava à qual ela pertence, da seguinte forma: $\mathrm{DO}_{2}$, é uma nota DÓ uma oitava acima da original, portanto, pertence à segunda oitava, como definimos na seção anterior. Observe a Tabela 1:

Tabela 1 - Escala Pitagórica

\begin{tabular}{l|c|c|c|c|c|c|c|c}
\hline Escala Pitagórica \\
\hline Nota & DO $_{1}$ & RE & MI & FÁ & SOL & LÁ & SI & DO $_{2}$ \\
\hline Definição & $1^{\mathrm{a}}$ & $2^{\mathrm{a}}$ & $3^{\mathrm{a}}$ & $4^{\mathrm{a}}$ & $5^{\mathrm{a}}$ & $6^{\mathrm{a}}$ & $7^{\mathrm{a}}$ & $8^{\mathrm{a}}$ \\
\hline Fração & $\mathrm{c}$ & & & $3 \mathrm{c} / 4$ & $2 \mathrm{c} / 3$ & & & $1 \mathrm{c} / 2$ \\
\hline
\end{tabular}

Fonte: Elaborada pela autora. 
Desse modo, utilizaremos a mesma definição utilizada por Pereira (2013, p.25), que se chama “o Ciclo das Quintas” e que, segundo o autor, é um método usado mundialmente para obter notas anteriores ou posteriores a uma nota dada.

Definição: Em termos de comprimento de corda, a quinta (ou quinta justa) de uma nota musical qualquer é determinada por:

$Q=\frac{2}{3} \cdot X_{n}, X_{n}$ é uma nota musical.

Partindo de uma nota $\mathrm{DÓ}_{1}$ com unidade de comprimento 1, podemos calcular todas as demais notas pelo Ciclo das Quintas. Observe:

- A Quinta de $\mathrm{DO}_{1}: Q=\frac{2}{3} . D \mathrm{O}_{1} \rightarrow Q=\frac{2}{3} \cdot 1=\frac{2}{3}=S O L_{1}$.

- A Quinta de $F A_{1}: Q=\frac{2}{3} \cdot F \hat{A}_{1} \rightarrow Q=\frac{2}{3} \cdot \frac{3}{4}=\frac{6}{12}=\frac{1}{2}=D \mathrm{O}_{2}$.

- A Quinta de $\mathrm{SOL}_{1}: Q=\frac{2}{3} . S O L_{1} \rightarrow Q=\frac{2}{3} \cdot \frac{2}{3}=\frac{4}{9}=R \mathrm{E}_{2}$

- Então $R \dot{E}_{1}=2 \cdot R \hat{E}_{2}=2 \cdot \frac{4}{9}=\frac{8}{9}$

- A Quinta de $\mathrm{RE}_{1}: Q=\frac{2}{3} \cdot R \hat{E}_{1}=\frac{2}{3} \cdot \frac{8}{9}=\frac{16}{27}=L \hat{\mathrm{A}}_{1}$.

- A Quinta de $L A_{1}: Q=\frac{2}{3} \cdot L \hat{A}_{1}=\frac{2}{3} \cdot \frac{16}{27}=\frac{32}{81}=M I_{2}$

- Então $M I_{1}=2 \cdot M I_{2}=2 \cdot \frac{32}{81}=\frac{64}{81}$

- A Quinta de $\mathrm{MI}_{1}: Q=\frac{2}{3} \cdot M I_{1}=\frac{2}{3} \cdot \frac{64}{81}=\frac{128}{243}=S I_{1}$

Assim, analogamente, podemos obter outras notas em diferentes oitavas (vide Tabela 2); de maneira mais clara, se iniciarmos a oitava em $\mathrm{DO}_{2}$, a última nota da escala diatônica deverá ser $\mathrm{DO}_{3}$. Por intermédio dos cálculos realizados anteriormente, conseguimos uma oitava completa, conforme a tabela a seguir. 
Tabela 2 - Fração do comprimento/ Escala Diatônica

\begin{tabular}{l|c|c|c|c|c|c|c|c}
\hline \multicolumn{1}{l}{ Escala Pitagórica } \\
\hline Nota & DO1 & RE & MI & FÁ & SOL & LÁ & SI & DO2 \\
\hline Definição & $1^{\mathrm{a}}$ & $2^{\mathrm{a}}$ & $3^{\mathrm{a}}$ & $4^{\mathrm{a}}$ & $5^{\mathrm{a}}$ & $6^{\mathrm{a}}$ & $7^{\mathrm{a}}$ & $8^{\mathrm{a}}$ \\
\hline Fração & $\mathrm{c}$ & $8 \mathrm{c} / 9$ & $64 \mathrm{c} / 81$ & $3 \mathrm{c} / 4$ & $2 \mathrm{c} / 3$ & $16 \mathrm{c} / 27$ & $128 \mathrm{c} / 243$ & $1 \mathrm{c} / 2$ \\
\hline
\end{tabular}

Fonte: Elaborada pela autora.

Dessa forma, é possível transportar esse conhecimento matemático a respeito da música para um violão ${ }^{14}$.

Porém, conforme foi passando o tempo, e com o surgimento de novos sons e instrumentos musicais, a escala Pitagórica já não era suficiente. Assim, na Idade Moderna surgiu a Escala temperada.

\section{A escala temperada}

Até a Idade Média, a escala Pitagórica era facilmente aceita, porém alguns matemáticos da época notaram que havia diferenças entre os intervalos de DÓ para RÉ e de RÉ para MI. Foi desenvolvida, portanto, a Escala Temperada, na qual seriam introduzidas, nesses intervalos, as novas notas DÓ sustenido (DÓ\#), que é a mesma coisa que RÉ bemol; FÁ sustenido (FÁ \#), que é a mesma coisa que Sol bemol ( $\mathrm{Sol}_{\mathrm{b}}$ ); Sol sustenido (Sol\#), que é a mesma coisa que Lá bemol (LÁ $)$ e, por fim, Lá sustenido (LÁ \#), que é mesma coisa que SI bemol $\left(\mathrm{SI}_{\mathrm{b}}\right)$. Quando afirmamos ser a mesma coisa, dizemos que essas notas musicais possuem o mesmo som; o que as difere no uso da nomenclatura "bemol" ou "sustenido" diz respeito à ascendência (da nota mais grave para a mais aguda) ou descendência (da nota mais aguda para a mais grave). Essas notas foram denominadas enarmônicas.

Essa nova escala já não era mais dividida por tons e sim por semitons, e é dessa forma até os tempos atuais, ou seja, matematicamente podemos entender que 1 tom $=2$ semitons. Observe a escala temperada em um teclado:

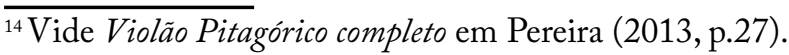


Figura 3 - A Escala Temperada

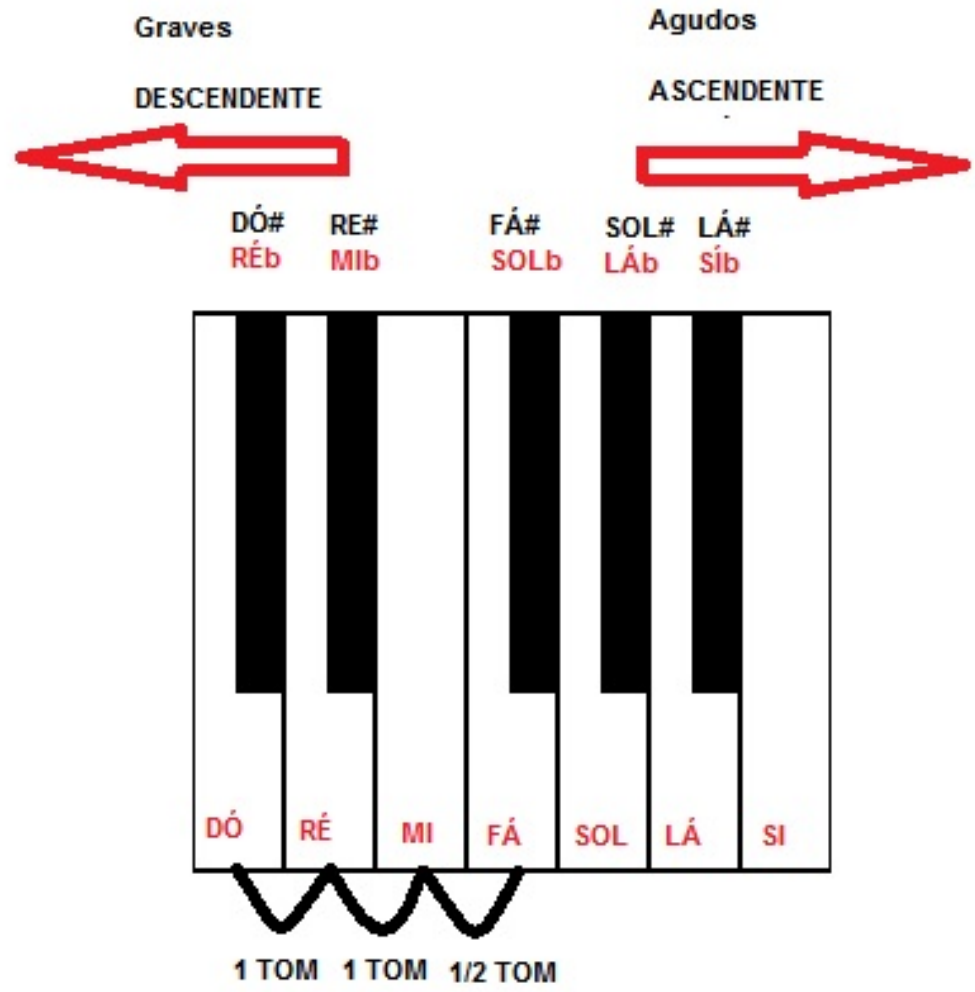

Fonte: Elaborado pela autora.

Entre a transição do uso da escala pitagórica para a utilização da escala temperada, alguns teóricos apresentaram opiniões divergentes a respeito da mudança, se ela realmente seria necessária e também matematicamente bem definida.

Alguns estudiosos, como Giovani LanFranco (1582-1647), utilizavam ambas as escalas; de acordo com Bromberg e Saito (2017), usavam a escala Pitagórica para vozes e a escala temperada, em sentido ascendente, para instrumentos; porém Gioseffo Zarlino (1517-1590) discordava do uso da escala temperada: “[...] explicava que o músico, assim como o aritmético, deveria valer-se apenas dos números necessários e, assim sendo, apenas de determinados sons, aqueles definidos de acordo com a sua teoria pitagórica." (BROMBERG; SAITO, 2017, p. 129). 
É importante ressaltar que, no período histórico em que a escala temperada estava sendo firmada no meio músico/matemático, surgiria, também, o estudo dos Logaritmos. Segundo Pereira (2013, p.42), "a escala temperada pode ser interpretada como uma escala logarítmica de base 2." Pois bem, para autores da época da Idade Média, como Vicenzo Galillei (1520-1591), já não era primordial a efetividade da música prática das divisões do monocórdio, pois o sistema temperado dividia uma oitava em doze partes iguais e se utilizava da divisão do tom em dois semitons, como vimos no início desta seção (vide Tabela 3). Assim sendo, utilizando a escala temperada, teríamos o seguinte:

Tabela 3 - Escala Temperada

Escala Pitagórica

\begin{tabular}{l|c|c|c|c|c|c|c|c|c|c|c|c|c}
\hline Nota & DÓ1 & DÓ\# & RÉ & RÉ\# & MI & FÁ & FÁ\# & SOL & SOL\# & LÁ & LÁ\# & SI & DO2 \\
\hline Fração & 0 & $1 / 12$ & $2 / 12$ & $3 / 12$ & $4 / 12$ & $5 / 12$ & $6 / 12$ & $7 / 12$ & $8 / 12$ & $9 / 12$ & $10 / 12$ & $11 / 12$ & 1 \\
\hline
\end{tabular}

Fonte: Elaborado pela autora.

Atente nos expoentes da progressão geométrica associada à escala temperada:

$$
2^{0}, 2^{\frac{1}{12}}, 2^{\frac{2}{12}}, 2^{\frac{3}{12}}, 2^{\frac{4}{12}}, 2^{\frac{5}{12}}, 2^{\frac{6}{12}}, 2^{\frac{7}{12}}, 2^{\frac{8}{12}}, 2^{\frac{9}{12}}, 2^{\frac{10}{12}}, 2^{\frac{11}{12}}, 2^{1}
$$

Temos atribuído a invenção dos logaritmos a John Napier (15501617) que, a respeito de sua criação, citou: "Na medida das minhas possibilidades, proponho-me a evitar as difíceis e aborrecidas operações do cálculo, cujo tédio constitui um pesadelo para muitos dos que se dedicam ao estudo da Matemática”(BARCO, 1997, p. 92) Dessa maneira, podemos facilmente utilizar suas teorias para mostrar os intervalos de tons entre as notas nas escalas temperadas.

sucessivamente.

Por exemplo: $\quad \log _{2} 2^{0}=0, \log _{2} 2^{\frac{1}{12}}=\frac{1}{12} \quad$ e, assim,

Um intervalo é definido, segundo Pereira (2013), como a divisão de dois intervalos quaisquer. Pela tabela anterior, sabemos que de $\mathrm{DO}_{1}$ à nota 
RÉ, há um intervalo de 1 tom. Observe a demonstração utilizando as propriedades de logaritmo.

$$
\begin{gathered}
I=\frac{I(A)}{I(B)}=\frac{R \mathrm{E}}{D \mathrm{O}_{1}}=\log _{2} I=\frac{\log _{2} 2^{\frac{2}{12}}}{\log _{2} 2^{0}} \rightarrow \log _{2} I=\log _{2} 2^{\frac{2}{12}}-\log _{2} 2^{0} \\
\log _{2} I=\frac{2}{12}-0=\frac{2}{12}=2 \cdot \frac{1}{12}
\end{gathered}
$$

Logo, o intervalo é de 2 semitons, que é igual a 1 tom. De maneira análoga, podemos comparar outros intervalos.

Neste momento, talvez você pergunte: Esse logaritmo é o mesmo que aprendi na escola? Sim, é o mesmo! Uma matéria feita por Luiz Barco à Superinteressante, em 1997, dizia que o "piano é uma tábua de logaritmos". Para fins de curiosidade, no artigo da mesma revista, lemos: "A intensidade de um som, expressa em bels, é o logaritmo decimal (na base 10) de sua intensidade física”. Portanto, mais uma vez, a Matemática influenciou a música e vice-versa.

Ainda sob a influência da música pitagórica, podemos citar o ritmo e a métrica (forma de se pronunciar as palavras na melodia), que assumiram forte característica na música barroca no século XVIII, de forma que foram resgatadas dos antigos as regras de retórica e linguagem: “[...] alguns autores barrocos tentaram padronizar e classificar estes grupos métricos de acordo com seus propósitos moral e estético, sob uma teoria que se chamou Rhyhmopoeia" (BROMBERG; SAITO, 2017, p. 111). Também no século XVIII, o matemático Joseph Saveur (1653-1716) declarou ter descoberto uma ciência maior que a música, a ser chamada de acústica, mas, segundo Bromberg e Saito (2017), ao contrário do que se pensa, esse não foi o fim da música fundamentada pela matemática, ou seja, permaneceu o conceito de som natural (produzido pela voz humana) e som instrumental (artificial), como já era aceito na época. 


\section{Considerações finais}

Por meio desse breve passeio da Matemática à Música e da Música à Matemática, podemos observar o quanto a música era importante na formação do cidadão da Antiguidade e como essas duas ciências, em conjunto, poderiam convergir de modo a elevar o ser humano ao mundo das ideias, segundo Platão. Nem sempre houve total concordância entre as opiniões acerca da definição musical ou se ela pertencia ao Quadrivium ou ao Trivium, mas uma coisa que pudemos evidenciar durante todo esse percurso foi que os cálculos matemáticos de Pitágoras ou suas teorias não estavam errados, pois, se estivessem, não poderiam ser aplicados no mundo material.

Em vários momentos, a música foi retratada como, de certa forma, um remédio para a alma, para elevar o espírito. Quem nunca ouviu uma música para relaxar? Será que é o som que produz em nós uma sensação boa, ou seriam os números que, sem percebermos, nos remetem a isso?

Outro ponto importante que ressaltamos é o fato de a álgebra, demonstrada por meio de classes de equivalência, poder explicar, como vimos no item A música por Pitágoras e suas implicações, a construção das outras notas musicais. Isso seria interessante para trabalhar em sala de aula com alunos de graduação, os quais veriam, na prática, algo que muitas vezes parece abstrato, assim como a música poderia ser trabalhada junto com os logaritmos no ensino fundamental, tornando a matemática mais atrativa aos alunos. A esse respeito, Barco (1997) afirma que, quando criança, não gostava de matemática, não fazia sentido para ele, até o dia em que seus irmãos apresentaram um artigo no qual havia a contextualização de logaritmo e música. Quando todo aquele conteúdo foi assimilado, ele percebeu o quanto poderia ser prazeroso estudar matemática. Seguindo esse raciocínio, o experimento proposto neste capítulo seria um bom começo.

Para finalizar, Hawking (1988, p.32) escreve o seguinte: "Portanto, caso se acredite que o universo não é arbitrário, mas sim governado por leis definidas, será preciso, em última análise, combinar teorias parciais numa outra, completa e unificada, capaz de descrever tudo no universo". Num momento da história da humanidade, a música se bastou como a teoria que unificaria tudo, desde o movimento dos astros até nossos sons e silêncios. 


\section{Referências}

ABDOUNUR, O. J. Matemática e Música: O pensamento analógico na construção de significados. São Paulo: Editora Escrituras,1999.

BARCO, L. A matemática do som. Revista Superinteressante, v.119, ago. 1997,

BRITO, A. J. B. O Quadrivium na obra de Isidoro de Sevilha. 1999, 150f. Tese (Doutorado em Educação) - Faculdade de Educação, Universidade Estadual de Campinas, Campinas, 1999 .

BROMBERG, C.; SAITO, F. As matemáticas, o monocórdio e o número sonoro. São Paulo: Livraria da Física, 2017.

HAWKING, S.W. Uma breve história do tempo: do Big Bang aos buracos negros. Tradução de Maria Helena Torres. Rio de Janeiro: Rocco, 1988.

OLIVEIRA, G.M. Os Princípios Cosmológicos de Filolau e a Música. 2010, 101f. Dissertação (Mestrado em Filosofia)- Universidade Católica de São Paulo, São Paulo, 2010.

PEREIRA, M.C. Matemática e música: de Pitágoras aos dias de hoje. 2013, 91f. Dissertação (PROFMAT)- Universidade Federal do Estado do Rio de Janeiro, 2013.

PLATÃO. Timeu-Crítias. Tradução de Rodolfo Lopes. Coimbra: [s.n.], 2011. ISBN 978989-8281-84-5.

SANTOS, M.P. Pitágoras e o tema do número. São Paulo: IBRASA, 2000.

SANTOS, L.; MOTTA, N. Certas coisas. Rio de Janeiro: Estúdio Transamérica, 1984. Disponível em: https:/www.vagalume.com.br/lulu-santos/certas-coisas.html. Acesso em 14 de abril de 2015 .

ZALESKI, D.F. Matemática e Arte. Belo Horizonte: Editora Autêntica, 2013. (Coleção Tendências em Educação Matemática). 


\section{A INFLUÊNCIA DA ESCOLA PITAGÓRICA NAARQUITETURA}

Islenis Carolina Botello Cuvides

O princípio de todas as coisas é a mônada ou unidade; desta mônada nasce a dualidade indefinida que serve como substrato material para a mônada, que é sua causa; da mônada e da dualidade indefinida, surgem os números; dos números, pontos; dos pontos, linhas; das linhas, figuras planas; das figuras planas, corpos sólidos; de corpos sólidos, corpos sensiveis, cujos componentes são quatro: fogo, água, terra e ar; esses quatro elementos são trocados e transformados totalmente um no outro, combinando-se para produzir um universo animado, inteligente e esférico. Diógenes Laercio (1792, p. 194).

\section{Introdução}

Vários foram os arquitetos que, com base nos ensinamentos da Escola de Pitágoras, contribuíram para a construção de cidades, templos, casas, igrejas, mansões, jardins e hospitais. Alguns, com seus planos, e outros, com suas obras arquitetônicas. Eles não só foram arquitetos, também foram escultores, carpinteiros, pintores, em uma palavra: artistas. Mas de onde vem a inspiração para criar essas belas construções? E o que pode ser definido como formoso ou belo? Por que o que era perfeito para eles, ainda permanece belo para nós em qualquer parte do mundo? Por que somos cativados por edifícios como as pirâmides egípcias, a Muralha da China, o Partenon, o Coliseu Romano, o Taj Mahal, a Igreja da Sagrada Família, a Catedral de Notre-Dame,o Castelo de Santo Ângelo, o Museu do Amanhã, entre outros?

É preciso mergulhar na história da arquitetura e conhecer alguns de seus pilares, para podermos encontrar algumas respostas para as anteriores perguntas. Vale a pena antes observar ao leitor que neste capítulo apresentaremos um pouco da história da arquitetura, sem fazer necessariamente um estudo historiográfico profundo. 
Embora o objetivo do presente capítulo seja conhecer como foram usados os conhecimentos desenvolvidos pela Escola Pitagórica, começaremos com uma aproximação do primeiro tratado conhecido da arquitetura e, no transcorrer do capítulo, encontraremos como se destacam aqueles conhecimentos pitagóricos com a tríade da arquitetura clássica, solidez-utilidade-beleza.

\section{Um início que não é a origem}

De Architectura foi o primeiro tratado de arquitetura que tem chegado até nós, escrito pelo arquiteto romano chamado Marco Vitrúvio Polião (90 a.C.- 20 a.C.), durante o império de Augusto (século I a.C.). O tratado consta de dez livros que demonstram o profundo conhecimento do autor sobre escritos anteriores gregos e romanos, hoje perdidos, e que descrevem de maneira muito prática os métodos de construção e os materiais, assim como apresentam ideias e especulações estéticas sobre os grandes princípios de harmonia e simetria.

Embora seja um livro antigo, seus ensinamentos ainda são seguidos em programas de arquitetura, e alguns de seus egressos conhecem ou já ouviram falar do Vitrúvio; similarmente, isso acontece com Os Elementos de Euclides, um livro que é de estudo, tanto nos programas de formação de professores de matemática como dos matemáticos ao redor do mundo.

De Architectura Libri Decem expõe, sistematicamente, os aspectos que devem ser conhecidos pelas pessoas que querem construir. No livro original não se apresentam imagens, mas nas algumas traduções as têm colocado para acompanhar as indicações que fez Vitrúvio e, assim, oferecer ao leitor melhor ideia do que se descreve no Tratado. Justamente sobre a ausência das imagens, Roth (1999) pondera que "alguns eruditos têm sugerido que os arquitetos gregos não fizeram desenhos no sentido que os entendemos hoje, sugerindo também que deviam trabalhar na obra em direto contato com os pedreiros e que não deviam precisar de desenhos abstratos" (ROTH, 1999, p. 113).

A palavra arquiteto é de origem grega e seus componentes - arkhos significa "chefe" e tekton, "construtor" ou "artesão". De acordo com Platão, em Politicus, os arquitetos não eram obreiros senão diretores de obreiros e, 
consequentemente, possuíam conhecimento teórico e prático. Entretanto, conforme Roth (1999), antigamente existiam arquitetos que eram também sacerdotes, como Imhotep ${ }^{1}$ e Amenófis filho de Hapu (1440 a.C. - 1360 a.C.), ou faraós como Senemut (c. 1480 a.C. - 1458 a. C.)².

De acordo com Raskin (1974), o arquiteto deve ser considerado muito mais do que um mero desenhador de edifícios, por mais elegantes, fascinantes e eficientes que possam ser. Como mencionamos anteriormente, o arquiteto deve ter conhecimentos práticos e teóricos, tem que saber como justificar suas propostas e ações, baseando-se em duas particularidades da arquitetura: o significado e o significante. Segundo Vitrúvio (1997, p. 26):

Certamente, para todas as atividades e artes, mas especialmente para a arquitetura, pertencem "o significado" e o "significante". O significado é a coisa proposta, da qual se fala; o significante é a evidência baseada na lógica dos conceitos, com argumentos teóricos e científicos (VITRÚVIO, 1997, p. 26).

Assim, o significado, o objeto e o significante são todos os argumentos que pretendem responder ao objeto arquitetônico desenvolvido, construído ou idealizado. Vitrúvio definia a arquitetura como uma ciência adornada com numerosos ensinamentos teóricos e com diversas instruções, que servem de opinião para julgar todas as obras que alcançam sua perfeição por meio das outras artes. Por isso, ela é considerada como ciência e arte da construção feita por um sujeito que adquire o conhecimento a partir de outras disciplinas, com o objetivo de criar o mais perfeito, belo e eficiente edifício.

\footnotetext{
${ }^{1} \mathrm{O}$ primeiro arquiteto de quem se tem notícia é Imhotep (2655-2600 a.C.) que serviu como arquiteto do faraó Zoser, aproximadamente entre os anos 2635 e 2595 a.C. Em uma estátua de Zoser, aparecem seus títulos: "Chanceler do Rei do Egito, Doutor, Primeiro na linhagem do Rei do Alto Egito, Administrador do Grande Palácio, Nobre hereditário, Sumo Sacerdote de Heliópolis, Construtor, Carpinteiro-Chefe, Escultor-Chefe, e Feitor-Chefe de Vasos”.

${ }^{2} \mathrm{~A}$ obra mais grandiosa de Senemut foi o Templo de Hatshepsut em Deir el-Bahri, que foi construído na margem direita do Nilo, à entrada do Vale dos Reis.
} 


\section{Relevância de outras disciplinas em arquitetura}

Por meio da leitura da obra de Vitrúvio, De Architectura, pode-se ver a importância das várias ciências, as quais ele destaca como qualidades de um arquiteto. Para Vitrúvio, um arquiteto deve ser engenhoso e inclinado ao trabalho, pois não é possível tornar-se um arquiteto experiente se não se possui talento e não se tem conhecimentos teóricos, ou vice-versa; o arquiteto deve ser instruído, hábil no desenho; competente em geometria; leitor atento dos filósofos; entendido na arte da música; documentado em medicina; ilustrado na jurisprudência; especialista em astrologia e em movimentos do cosmos.

Vitrúvio lista várias qualidades e ciências (ver Figura 1) que um arquiteto deve dominar ou conhecer, sem necessidade de ser um experto, pois podem ser de utilidade no momento do desenho, planificação e construção do edifício.

Figura 1 - As ciências de que um arquiteto deve ter conhecimentos

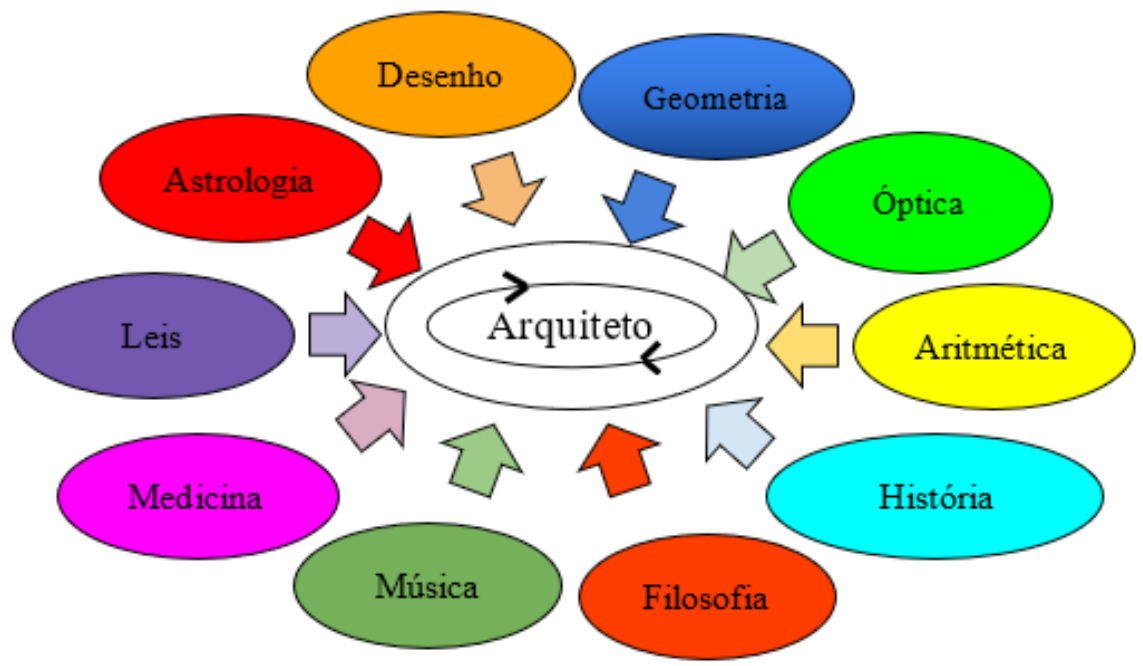

Fonte: Elaborada pela autora tendo em conta a Vitrúvio (1997). 
Por que são importantes essas diferentes disciplinas para a formação do arquiteto e em seu trabalho? Dentro de seu tratado, Vitrúvio (1997) nos responder essa questão ao destacar que:

- A arte do desenho permite que, por meio de reproduções gráficas, o arquiteto possa criar uma imagem do trabalho que quer fazer;

- A geometria oferece múltiplas ajudas à arquitetura, ao facilitar a prática pelo uso da régua e do compasso, com os quais facilmente se fazem desenhos dos edifícios, por meio dos traçados de suas linhas, seus níveis, suas esquadrias;

- A óptica propicia colocar corretamente os pontos de iluminação, segundo a disposição concreta do céü;

- Por meio da aritmética, são calculados os custos dos edifícios; é mostrado o motivo das suas medições e, com o apoio e com o método da geometria, são decifrados os difíceis problemas da simetria.

- A história, frequentemente, é a fonte de abundantes adornos, os quais devem responder ao motivo da obra, apoiada em argumentos históricos.

- A filosofia aperfeiçoa o arquiteto, dando-lhe uma alma generosa, para não ser arrogante, mas sim condescendente, justo, firme e generoso, o que é o principal; na verdade, é impossível construir um trabalho sem honestidade.

- A música permite ao arquiteto familiarizar-se com a ciência matemática dos sons e, consequentemente, ser capaz de esticar corretamente as bestas ${ }^{4}$, as catapultas e as máquinas de guerra.

\footnotetext{
${ }^{3}$ De acordo com o discurso de Vitrúvio, seria a óptica geométrica. E.g.: Todos os esforços devem ser feitos para garantir que todos os edifícios estejam perfeitamente iluminados. [...] A altura das paredes comuns e as ruas estreitas são um inconveniente real para o brilho das casas (VITRÚVIO, 1997, p. 157-158).

${ }^{4}$ Arma antiga, composta por um arco e por um cabo muito tenso, com que se arremessavam setas e pelouros. In Dicionário Priberam da Lingua Portuguesa [em linha], 2008-2013, $<$ https://www.priberam.pt/dlpo/besta> [consultado em 18-02-2018].
} 
- É necessário que conheça medicina,em razão dos diferentes climas - em grego climata - tanto da atmosfera como das localidades ou áreas concretas, pois podem ser saudáveis ou prejudiciais, precisamente pela qualidade de suas águas. Sem levar em conta esses aspectos, não é possível construir uma casa saudável.

- A arquitetura diferencia-se da música, da pintura, ou da poesia, pois se estabelece a partir de uma relação dono da casa « arquiteto, na qual, com um contrato amparado pelas leis, se protegem ambas as partes contra possíveis fraudes, sem qualquer tipo de decepção.

- Da astrologia ${ }^{5}$ o arquiteto conhece os pontos cardinais: leste, oeste, sul e norte; e a estrutura do céu, os equinócios, os solstícios e os movimentos orbitais das estrelas. Se a Astrologia for ignorada, é absolutamente impossível conhecer a disposição e a estrutura dos relógios.

Um dos objetos da investigação da matemática na antiguidade clássica era a óptica. De acordo com Saito (2015), para Aristóteles, a óptica era uma das ciências subordinadas e demonstrava seus teoremas recorrendo aos princípios da geometria e da aritmética. Durante a Idade Média, os árabes fizeram estudos sobre óptica, sobretudo o denominado "Pai da Óptica" Abú Alí Al-Hasan Ibn Al-Haytam6 (965-1039), que criou lentes, espelhos, e descobriu as leis de refração; foi o primeiro a descrever, exatamente, as partes do olho humano e dar uma explicação científica do processo da visão.

Saito (2015) menciona que a óptica ainda não era uma "ciência da luz”, e que o estudioso dela, naquela época, não só incursionava em aspectos anatômicos, senão também em físicos, filosóficos e geométricos. Assim, o fato de ser uma ciência ligada à matemática também estava unida a outras, por isso se denominava como "a ciência mista" no século XVII.

É interessante como Vitrúvio não só aborda a importância de cada uma das disciplinas anteriores, como também a relação entre elas. Por

\footnotetext{
${ }^{5}$ Nesse período, não se tinha diferença entre a astrologia e a astronomia; com o advento do telescópio e dos estudos de Kepler, Galilei e outros, no século XVII, elas se separaram.

${ }^{6}$ Conhecido no Ocidente como Al-Haytam ou Alhazen.
} 
exemplo, os aspectos interdisciplinares que há entre os astrólogos e os músicos, quando nos descrevem a existência da afinidade das estrelas e das sinfonias em relação aos quadrados e triângulos, em uma quarta e em uma quinta; e, também, quando ressalta o trabalho dos geômetras com o tema da visão que, em grego, se chama logos ópticos. Mais adiante, retomaremos algumas dessas relações ao mostrar como o trabalho dos arquitetos pode ter se embasado nos estudos da Escola Pitagórica.

\section{Quais são as partes [essenciais] da arquitetura clássica?}

A prática do desenho, como foi descrito pelo Vitrúvio, é moderna e familiar, já que nos planos do andar (ichnographia), desenhados com régua e compasso, incluem desenhos de elevações (ortographia), concebidos como "uma imagem vertical da fachada", e perspectivas (scaenographia) com sombras e planos laterais que se afastam para convergir em um ponto de fuga.

Da mesma forma, dentro dos elementos essenciais mencionados por Vitrúvio, encontramos a solidez (depende da bondade dos fundamentos, da eleição dos materiais e seu uso, que deve ser feito para a ordenação, disposição e proporção adequadas entre todas as partes), a utilidade e a beleza (conseguidas pela disposição correta das partes de um edifício de modo que não causem nenhum obstáculo). Do anterior, Vitrúvio (1997) define esses conceitos para esclarecer sua teoria da seguinte maneira:

- Ordenação (ordinatio) é o ajuste do tamanho das várias partes, segundo seus diversos usos, que requer a devida consideração das proporções gerais da estrutura: ela surge da dimensão (quantitas),

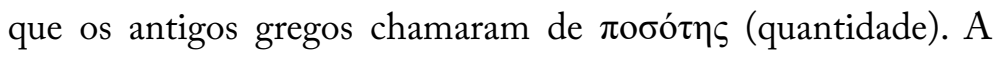
quantidade, por sua vez, é o estabelecimento de módulos retirados dos elementos da própria obra e a execução agradável da obra como um todo, com base nas partes individuais dos elementos.

- Disposição (dispositio) é a colocação adequada dos elementos e o resultado correto do trabalho, de acordo com a qualidade de cada um deles. A disposição é divisível em três cabeças que, consideradas em conjunto, constituem o desenho: estas, por parte 


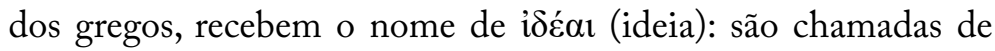
ichnografia (plano geométrico), ortografia (elevação geométrica) e cenografia (elevação perspectiva).

a) o plano geométrico requer o uso do compasso e da régua; com eles vai-se formando o arranjo dos planos, que serão usados mais tarde nas superfícies planejadas para o futuro edifício;

b) elevação geométrica é a elevação da frente, ligeiramente sombreada, e mostrando as formas do edifício pretendido;

c) elevação perspectiva exibe a frente e um lado, recuado, devidamente sombreado, as linhas sendo desenhadas para os seus próprios pontos de fuga.

- Proporção (eurythmia): é essa harmonia agradável entre as várias partes de um edifício, que é o resultado de um acordo simples e regular entre eles; a altura para a largura está para o comprimento e cada um desses para o todo. É aquele que forma o conjunto de todas as partes do trabalho, dando-lhes uma aparência bonita, quando simetricamente a altura corresponde à largura, a largura ao comprimento e em todo o conjunto brilha uma correspondência adequada.

- Beleza (decor): Ela é encontrada naquele trabalho cujo todo e os detalhes são adequados para a ocasião.Isso decore da circunstância, do costume e da natureza.

- Uniformidade (symmetria): A uniformidade é a paridade das partes umas para as outras; cada uma correspondendo com o seu oposto, como na figura humana. Os braços, pés, mãos, dedos são semelhantes e simétricos uns com os outros.

- Economia (distributio): A economia consiste em uma aplicação devida e adequada dos meios oferecidos, de acordo com a capacidade do empregador e a situação escolhida, cuidando que as despesas sejam prudentemente realizadas.

Ao buscar a perfeição, os arquitetos deixaram um legado para todas as gerações. Algo que seja completo, sem defeitos e que cumpra um propósito, tal como propõe a ríade solidez-utilidade-beleza. Por isso é que Vitrúvio 
busca a beleza mediante um sistema de proporções ${ }^{7}$ na arquitetura, as quais são descritas no terceiro e quarto livro. Vitrúvio oferece as quantidades das partes - porque não dá os números das medidas especificas - e as proporções para construir as bases e colunas ${ }^{8}$ das ordens: a Dórica, a Jónica e a Coríntia 9 .

\section{Alguns elementos visuais da forma arquitetônica: o círculo e o quadrado}

Retomando a característica da arquitetura de usar outras disciplinas, destacamos a sua importância para realizar os desenhos ou planos, e levá-los à prática na construção de edifícios. Dentro dos desenhos das construções realizadas, contemplamos o uso de figuras geométricas, entre elas: o círculo, o quadrado, o triângulo, o retângulo e outros polígonos. Do mesmo modo, são utilizados corpos geométricos: a esfera, o cubo, prismas, dodecaedros e outros.

$\mathrm{Na}$ arquitetura descrita por Vitrúvio e praticada no Ocidente até o final da Idade Média, o círculo e o quadrado são símbolos primordiais. E, dentro da filosofia da Escola Pitagórica ${ }^{10}$, o círculo era reconhecido por

\footnotetext{
${ }^{7}$ Defina-se dizendo que proporção é o respeito de todo o trabalho com suas partes, e o que as partes têm separadamente com a ideia do todo, de acordo com a medida de alguns deles. Porque, como no corpo humano, há respeito ou relação entre o pé, a mão, o dedo e as outras partes: então, nas obras perfeitas, um membro particular implica o tamanho do todo, por exemplo: pelo diâmetro de uma coluna ou ao longo de um Tríglifo, o tamanho de um templo é julgado (VITRÚVIO, 1997, p. 32).
}

${ }^{8}$ Pilar ou elemento estrutural que serve para sustentar um arco, teto ou outras partes de um edifício.

${ }^{9}$ As denominações dórica, jônica e coríntia surgem precisamente da composição ou estrutura de suas colunas. De acordo com Vitrúvio (1997), a ordem dórica era a mais antiga e surge na região de Acaia e do Peloponeso; foi uma resposta à proporção do corpo humano, especificamente do masculino, e se destacou nos edifícios por sua solidez e beleza. A ordem jônica aparece na Grécia oriental, e, assim como a dórica, queria responder à proporção do corpo humano, mas adaptando-a à esbelteza e delicadeza feminina, por exemplo, adornavam suas frentes e fachadas com cimácios e festões, colocando-os como se fossem os cabelos e, ao longo de todo o fuste, escavaram umas estrias, imitando as dobras das estolas usadas pelas mulheres. A última ordem, a coríntia, imita a delicadeza de uma menina, porque, devido à sua juventude, elas têm uma configuração composta de membros delicados e, através de seus ornamentos, conseguem efeitos muito bonitos, é um estilo mais decorativo e trabalhado.

${ }^{10}$ Embora o quadrado não seja mencionado nas obras de Laércio, Jâmblico, Platão como foi feito para o círculo (e.g. se menciona expressões tais como: “o quadrado do número ...", ou "a duplicação do quadrado...”) é comum encontrar na literatura coloquial que era um elemento esotérico da Escola Pitagórica, sendo isso um indício do que se atribui uma qualidade ao quadrado que não pertence à Escola Pitagórica. 
sua beleza: "das figuras sólidas a esfera é a mais linda: das planas o círculo" (LAERCIO, 1792, p. 201). Segundo Hani (1998), o círculo ou esfera representam a unidade ilimitada de Deus, a sua infinidade, a sua perfeição; e, na ordem cosmológica, o círculo representa o céu, instrumento da atividade divina que rege a vida sobre a terra, enquanto a terra é representada pelo quadrado (porque ela, de certa maneira, é "oferecida” à atividade do céu). O quadrado ou cubo forma a base estável dessa unidade e é a imagem da sua imutabilidade e da sua eternidade.

O tratado de Vitrúvio fala sobre o uso do círculo na construção dos teatros e a implementação do compasso e da régua. No entanto, Geertman (1980) encontrou que se aplicaram os círculos e arcos no desenho geométrico das salas das casas de Pompéia e em elementos arquitetônicos mais básicos da história da cultura persa, como em outras mais. De acordo com Kuilman (2011), essas formas geométricas são particularmente proeminentes nos lugares de culto (o fogo sagrado) do 'chatar taq' (quatro pilares): o círculo, que conduz à cúpula, representa a aproximação ao universo e suas conotações religiosas, e o quadrado, que leva ao altar, é a limitação da Terra, criada no encontro oposto de duas linhas de cruzamento.

Não só a geometria, na arquitetura, toma elementos no espaço e no plano; também há que se considerar as medidas, portanto, os números (que representam as quantidades das partes) e seus significados, assim como as proporções que cumpriram com uma ordem.

No primeiro tratado arquitetônico do Renascimento, De re aedificatoria ${ }^{11}$, de Leon Battista Alberti (1404-1472), além de destacar o círculo como a forma para construir os templos ou igrejas, também listou cinco figuras mais (o quadrado, o hexágono, o octógono, o decágono e o dodecágono), todas elas determinadas pelo círculo e como elementos essenciais para o desenho de planos arquitetônicos.

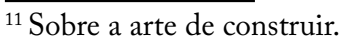




\section{A conexão dos números e as estruturas arquitetônicas}

Nos diálogos de Platão e Timeu ${ }^{12}$, encontramos um dos elementos da filosofia pitagórica, segundo o qual "a formação do mundo organizado a partir dos quatro elementos obedece inevitavelmente à proporção, isto é, à relação matemática. Como se tornará evidente, até o próprio demiurgo está atido às imposições da proporção matemática" (PLATÃO, 2011, p. 100, grifo nosso). Essa ideia da Escola Pitagórica foi criada com base no legado de Anaximandro de Mileto, professor de Pitágoras, e dos estudos no Egito e na Babilônia (PORFIRIO, 1987).

Precisamente, as proporções são apresentadas constantemente na obra de Vitrúvio, o que as tornou presentes no jogo criativo e no trabalho do arquiteto. Um exemplo de como os arquitetos têm consideração pela filosofia pitagórica anteriormente mencionada está no desenho do Panteão de Agripa, reconstruído por Públio Élio Trajano Adriano (76-138), em 126 d.C.

Segundo Joost-Gaugier (1998), Adriano era bem versado em aritmética e apaixonadamente interessado no Leste Grego; consequentemente, poderia ter-se voltado para fontes pitagóricas para enfrentar o problema de projetar seu novo Panteão. A continuação nos mostra alguns exemplos de como foram implementadas algumas ideias pitagóricas.

1. O Panteão foi construído em torno de um eixo central, com seu plano circular; sua orientação às quatro direções cardinais e o caráter hemisférico de sua cúpula sugerem preocupações cósmicas. Essas qualidades podem ser vistas como preocupações pitagóricas, de acordo com Burkert (1972).

2. A rotunda, a parte central e mais importante do desenho, é dominada pelo número um, conhecido pelos pitagóricos como unidade ou mônada ${ }^{13}$, por causa de seu caráter indivisível e por ser o único número perfeito no poder.

\footnotetext{
${ }^{12}$ Pitagórico, de acordo com Jâmblico (1988).

${ }^{13}$ Jâmblico (1988) explica a mônada como a mais autoritária dos números porque é o Sol que governa.
} 
3. $\mathrm{Na}$ cúpula gigante, abre-se o óculo ${ }^{14}$ que tem vinte e oito costelas que formam o cofre planetário, atingindo o cilindro de apoio abaixo. Para os pitagóricos, vinte e oito era o número da Lua, pois simbolizava o número de dias no mês lunar.

4. Correspondente à rotunda e às 28 costelas $^{15}$, são cinco anéis artesanais de cofres, sugerindo uma combinação muito incomum por padrões antigos. O número cinco, a média aritmética proporcional da Decad, de acordo com o Theon de Esmirna (c. 70 - c. 135) ${ }^{16}$, também foi o primeiro número totalmente circular, conhecido por meio de Aristóteles e de Anatólio de Laodiceia (início do século III - 283) - ambos considerados pitagóricos - como o casal ou número de casamento ${ }^{17}$, por ser a primeira combinação de ímpar e par, 3 e 2, masculino e feminino (BURKERT, 1972, p. 467).

Ao continuar com a leitura da estrutura arquitetônica, contemplamos que é ordenada, bonita e simbólica (JOOST-GAUGIER, 1998). Do mesmo modo, poderíamos encontrar algumas pistas sobre o possível uso das fontes pitagóricas, explicadas pela propagação do pitagorismo na Antiga Roma.

A propagação do pitagorismo no mundo ocidental começou ao final do primeiro século a. C. Sua difusão foi acompanhada por uma associação com as pseudociências, em particular a astrologia, a interpretação dos sonhos e a adivinhação. Ao estabelecer-se no mundo romano, o pitagorismo tentou unir-se às tradições próprias. Foi assim que Marcus Manilius

\footnotetext{
${ }^{14} \mathrm{Na}$ arquitetura, é uma abertura ou janela de forma circular ou oval, cuja função é fornecer iluminação.

${ }^{15}$ Uma costela é um suporte vertical usado para alinhar, apoiar ou reforçar as longarinas.

${ }^{16}$ Foi um filósofo, astrônomo e matemático grego, cujas obras foram fortemente influenciadas pela Escola Pitagórica. Preservou-se seu trabalho "Sobre a matemática usada para a compreensão de Platão", uma compilação introdutória da matemática grega.

${ }^{17}$ Temos que destacar que, para os Pitagóricos, o número um era um caso excepcional, sendo ao mesmo tempo par ou ímpar, feminino e masculino, por isso não se tinha em consideração a dupla 1 e 4 .
} 
(século I d.C. $)^{18}$, em seu poema astronômico, introduziu ao mundo romano os detalhes de signos zodiacais, influências no nascimento e horóscopos; e Caio Júlio Higino (64 a.C. - 17 d.C. $)^{19}$, em seu texto astronômico, ressaltou a importância do Sol ao governar sobre o zodíaco. Essas noções pitagóricas de ordem cósmica e harmonia universal foram atrativas para os imperadores romanos que as adotaram em sua cultura, a tal ponto que se aproveitaram disso para representar a si mesmos como deuses ${ }^{20}$.

\section{Teorema de Pitágoras na arquitetura}

Dentro das noções pitagóricas que têm servido à arquitetura para medir alturas, encontrar pontos para colocar objetos nas estruturas e aproveitar os espaços, está o teorema de Pitágoras. Embora esse teorema seja apresentado nas salas de aulas como se tivesse sido criado por Pitágoras de Samos, existem pesquisas de González (2008) e Santos ( 2010), entre outras, que mostram que esse teorema era conhecido por várias civilizações antigas, por exemplo, na cultura chinesa, persa, mesopotâmicas e egípcia.

Precisamente dentro da utilidade da geometria na arquitetura, encontramos indícios do uso do teorema de Pitágoras nos desenhos das construções de edifícios, e o uso específico de ternas pitagóricas tradicionais ${ }^{21}$. Não se tem encontrado uma fonte que especifique o uso do teorema por parte de um arquiteto, mas encontramos estudos que falam das relações desse teorema com as medidas de suas dimensões. Por exemplo, no plano do Templo de Athena (NABERS; WILTSHIRE, 1980; HOLLOWAY, 1966), ou na Basílica subterrânea na Porta Maggiore (SCHMELING, 1969).

Nabers e Wiltshire (1980) demonstraram que as três dimensões básicas do Templo -comprimento, largura e altura - produzem dois triân-

\footnotetext{
${ }^{18}$ Joost-Gaugier (1998) indica que Manilius, possivelmente, pertenceu à vertente pitagórica porque demonstra domínio dos temas da escola.

${ }^{19}$ Joost-Gaugier (1998, p. 33).

${ }^{20}$ E.g. O imperador Nero foi representado como Apolo ou Hélios. (LEHMANN, 1945).

${ }^{21}$ E.g. $\{2,3,4\},\{5,12,13\},\{7,24,25\},\{8,15,27\}$.
} 
gulos com base no teorema de Pitágoras ${ }^{22}$. Acompanhando as dimensões modulares de Holloway (1966) para comprimento e largura, Nabers e Wiltshire construíram o triângulo pitagórico com uma diagonal de 26 módulos. Vinte e seis módulos de quatro pés dóricos são iguais a 104 pés dóricos, uma dimensão que é a soma dos números pitagóricos $(10 * 10+4)=104)$.

O triângulo pitagórico citado é uma versão básica ou primitiva do triângulo cuja terna é $\{5,12,13\}$ multiplicado pelo fator de 8; assim, teríamos a nova terna $\{40,96,104\}$, que constitui um triângulo cujo perímetro é 240 ou $10 * 24$ pés dóricos.

Assim, um lado do triângulo mede 40 (ou $4 \times 10$ ) pés dóricos, outro lado 96 (ou $4 *(1 * 2 * 3 * 4)$ ), e sua hipotenusa $h=\sqrt{40^{2}+96^{2}}=\sqrt{1600+9216}=\sqrt{10816}=104, \quad$ (ou $(10 * 10+4))$. Do anterior, podemos vislumbrar que a construção do Templo não só estava relacionada com a ideia das ternas pitagóricas senão também com a teoria numérica de Pitágoras, especificamente os tetraktys, pois cada uma dessas medidas $\{40,96,104\}$ pode-se escrever como a soma, produto ou combinação dos números que expressam os tetraktys. Na seguinte seção do capítulo, será desenvolvido com maior aprofundamento esse conceito.

Outro exemplo é a basílica subterrânea na Porta Maggiore, que tem uma elaborada decoração de estuque ${ }^{23}$ nas abóbodas do cânion do navio e onde seus corredores laterais retratam uma variedade de cenas, da mitologia e da tragédia, que levaram alguns a interpretar a Basílica como o centro de culto da seita neopitagórica (SOREN; SOREN, 1999).

Schmeling (1969) determinou que as dimensões da Basílica expressam o teorema de Pitágoras; igualmente menciona o possível erro em seus valores ao tomar as medidas, mas, de todas as seitas místicas, especificamente os pitagóricos estavam interessados no misticismo numérico: $3^{2}+4^{2}$ $=5^{2}$, a fórmula de um triângulo retângulo. Com essas proporções em mente, ele mediu a basílica e, levando em conta que as paredes da basílica não são bastante retas, tomou valores aproximados.

\footnotetext{
${ }^{22} \mathrm{O}$ quadrado do comprimento da hipotenusa é igual à soma dos quadrados dos comprimentos dos catetos.

${ }^{23}$ Segundo Pinhal (1996), é a massa à base de cal, gesso, areia, cimento e água, usada no revestimento de paredes e de forros.
} 
Usando as dimensões do edifício encontradas nos desenhos em escala de Goffredo Bendinelli (1923) ${ }^{24}$ e os dados oferecidos por Fornari e Gatti (1918), Schmeling mediu, aproximadamente, do centro das paredes para a parede oposta de comprimento e largura. Para a altura, usou um segundo desenho da nave central de Bendinelli, dando as medidas: 11,75 m de longo; 7,3 $m$ de alto e 9,2 $m$ de amplo.

Logo, do anterior se tem que verificar que $11,75^{2}=7,3^{2}+9,2^{2}$. Daí, $7,3^{2}+9,2^{2}=137,93$ e $11,75^{2}=138,0625$. Assim, a quadratura desses números deixa uma discrepância de apenas $0,1325 \mathrm{~m}^{2}$, o qual é um erro produzido ao manipular números não exatos.

\section{Um número perfeito: Tetraktys}

O tratado De Architectura fala sobre vários números naturais, o que acontece se se multiplicarem, quais serão suas substâncias individuais e quais os seus nomes, se eles se juntarem, ou qual é o tipo de número deles. Embora Vitrúvio não mencione a palavra "tetraktys", ele menciona um número ao qual dá o adjetivo perfeito:

Os autores antigos fixaram um número perfeito, que é chamado número dez, pois é o número total dos dedos da mão; a partir da palma, descobriram o pé. A Platão, parecia-lhe perfeito o número dez porque somando cada uma das substâncias individuais - mônadas - se obtém a dezena (VITRÚVIO, 1997, p. 39, tradução nossa) ${ }^{25}$.

Do anterior, podemos perceber que Vitrúvio tinha conhecimentos, graças a "autores antigos", mas não há referência específica aos pitagóricos. No texto de Nicômaco, podemos encontrar claramente a associação do

\footnotetext{
${ }^{24}$ Em Bendinelli (1923), fala-se sobre um ensaio escrito por Franz Cumont (1868-1947) em 1918, onde se associa a basílica a um santuário, e fala-se que sua construção e utilização do subsolo fora por parte de uma seita neopitagórica, na qual predominaram os cultos órfico e dionisíaco.

${ }^{25}$ Texto original: "Los autores antiguos fijaron un número perfecto, que es el llamado número diez, pues es el número total de los dedos de la mano; a partir del palmo, descubrieron el pie. A Platón le pareció perfecto el número diez, ya que sumando cada una de las sustancias individuales - mónadas - se obtiene la decena”. (VITRÚVIO, 1997, p. 39).
} 
tetraktys como uma descoberta de Pitágoras, assim como se tornou parte do juramento dos membros da escola pitagórica ${ }^{26}$ :

Diz-se que o próprio Pitágoras determinou as proporções numéricas das concordâncias musicais fundamentais, uma afirmação que implica um conhecimento das proporções em geral; também foi dito que a descoberta do tetraktys era dele, e foi comemorado pelo juramento habitual dos irmãos pitagóricos, em vista de que os números figurados, certamente números triangulares, quadrados e oblongos, eram conhecidos nos primeiros dias (NICÔMACO, 1926, p. 18, tradução nossa) ${ }^{27}$.

Mais adiante, Nicômaco explica em que consiste o tetraktys: "A tétrade é um quadrado, é produzido a partir de $2+2$ e 2 ' 2 e, há muito tempo, foi reverenciado como potencialmente o dez, porque $1+2+3+4=10$ ". (NICÔMACO, 1926, p. 105, tradução nossa) ${ }^{28}$.

Figura 2-O Tetraktys Pitagórico

Fonte: Elaborado pela autora.

Assim, o tetraktys (ver Figura 2) pode comparar-se com o número perfeito do qual falava Vitrúvio, e do qual tínhamos indícios de que se

\footnotetext{
${ }^{26}$ Atualmente o tetraktys está relacionado com o Compasso e Quadrado Maçônico. Ver (KENNY, 2004, p. 8).

${ }^{27}$ Texto original: "Pythagoras himself is said to have determined the numerical ratios of the fundamental musical concords, a statement which implies a knowledge of the ratios in general; the discovery of the tetraktys, too, was said to be his, and was commemorated by the customary oath of the Pythagorean brethren, in view of which figurate numbers, certainly triangles, squares and heteromecic numbers, were known in the earliest days". (NICÔMACO, 1926, p. 18).

${ }^{28}$ Texto original: "The tetrad is a square, is produced from $2+2$ and $2 \times 2$, and had long been reverenced as potentially the decad, because $1+2+3+4=10$ " (NICÔMACO, 1997, p. 105).
} 
referia ao mesmo objeto definido por Nicômaco. Deve-se citar, também, que o tetraktys foi considerado parte do misticismo da Escola Pitagórica, onde Hermes, Hephaestus, Heracles e Dionysus compartilharam a tétrade, e onde, ao mesmo tempo, se contemplavam as proporções musicais que estão contidas nela, chamando-a de "harmonia". Da mesma forma, esse número tinha o especial significado de representar todas as dimensões possíveis (Figura 3).

Figura 3 - Dimensões a partir dos números do tetraktys

1

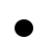

Gerador de dimensão

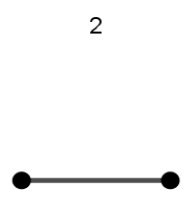

$\Re$

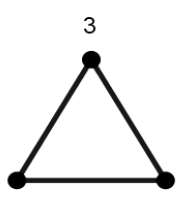

$\Re^{2}$

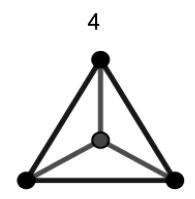

$\Re^{3}$

Fonte: Elaborada pela autora.

$\mathrm{Na}$ arquitetura românica, encontramos um exemplo de estrutura que, aparentemente, se baseou na tetraktys: um templo na Grécia Antiga. Holloway (1966) demonstrou que o desenho do Templo de Athena, em Paestum, construído no final do século VI d.C., tinha um triângulo com dez pontos em quatro linhas que expressam dez como a soma dos quatro primeiros dígitos. Holloway mostrou que o plano do templo foi baseado em um módulo de 4 pés dóricos de 0,328 m e que 10 módulos formaram a largura interaxial ${ }^{29}$ do peristilo ${ }^{30}$, enquanto 24 módulos formaram seu comprimento. $\mathrm{O}$ desenho expressou a soma e o produto dos tetraktys: $1+2+3+4=10$.

Além disto, na arquitetura do século XX, podemos encontrar outra estrutura que, aparentemente, demonstra o uso de ideias pitagóricas, entre elas o tetraktys: o Teatro Capitol de Melbourne, construído pelo casal

\footnotetext{
${ }^{29}$ Segundo Höcker (2006), espaçamento interaxial é um termo técnico moderno que, na arqueologia dos edifícios, denota a distância interaxial entre duas colunas. O espaço interaxial era um subconjunto claramente definido das distâncias axiais, ou seja, as distâncias entre os centros das quatro colunas de canto e, como tal, serviam como um dos parâmetros cruciais de projeto na arquitetura do templo.
}

${ }^{30}$ De acordo com Pinhal (1996), o peristilo é uma colunata ou série de colunas. 
Walter Burley Griffin (1876-1937) e Marion Mahony Griffin (18711961), em 1921. De acordo com Pont (2003), o teatro é um templo de pedra ou santuário de caverna que é inserido através de um portal. Pont (2003) menciona que os Griffins adotaram uma ideologia pitagórica secreta e tentaram desenvolver uma nova síntese de estética musical e arquitetônica, e o exemplo disso está no teto do Teatro Capitol, em Melbourne, mostrando o tetraktys diretamente acima da tela do cinema.

Outra caraterística proeminente do Capitólio é a proporção do quadrado duplo (1:2), que é a proporção da próxima consonância importante, a oitava ou o diapasão. Essa relação também determina o símbolo cósmico cruzado, que é proeminentemente exibido na fachada principal, bem como a subdivisão quadrangular ou o cortejo do cubo. Os Griffins impuseram assim à fachada um ritmo percebido de sólido a vazio, na proporção de 6:8, o que é equivalente a 3:4, a proporção que define o intervalo musical do quarto. Os pitagóricos chamaram-no de diatessarão, o terceiro das consonâncias fundamentais codificadas nos tetraktys.

É importante ressaltar que as proporções entre os números 1, 2, 3 e 4, números integrantes da tetraktys, estão presentes na arquitetura e, a partir delas, construíram-se templos, igrejas e monumentos de diferentes períodos ou estilos arquitetônicos, entre os quais se encontram o Romano, Gótico, Renascimento, Barroco, Rococó, e Palladianismo. Para conhecer com maior aprofundamento esses períodos ou estilos da arquitetura, e dizer do conjunto de características que identificam a tendência artística de uma época ou um autor, convidamos ao leitor fazer uma revisão dos autores (CONWAY; ROENISCH, 2006; COLE, 2003; ALBERTI, 1582).

\section{Proporções na arquitetura}

No desenho arquitetônico antigo, predomina o padrão de proporção sobre a medida (e.g. o desenho arquitetônico da Pompeia). Primeiro, era preciso cumprir as proporções harmônicas e aritméticas e, depois, se procedia a encaixar as partes por meio de um sistema metrológico. É precisamente por isso que Vitrúvio oferece recomendações para proporção, mas raramente dá as dimensões específicas para as peças arquitetônicas. 
Como nós lembramos, os métodos de desenho de Vitrúvio são baseados em sistemas modulares; no entanto, outro método de seu sistema consiste no uso do Atrium, para o qual o autor recomenda a construção de um retângulo adequado a partir da diagonal de um quadrado, pois, como esse quadrado terá uma medida modular, seria possível estabelecer que a medida de um lado do Atrium é $\sqrt{2}$ vezes ${ }^{31}$ o lado do módulo, é dizer um sistema baseado em $\sqrt{2}$. Portanto, houve desenhos com proporções entre números irracionais e números naturais para esse período em que os irracionais geraram grande comoção no mundo matemático, embora não tenha tido o maior impacto na arquitetura, devido ao interesse do arquiteto por ter uma ferramenta útil para seu trabalho.

Outro arquiteto que também utilizou as ideias pitagóricas foi Leon Battista Alberti. Uma das caraterísticas, dentro da obra de Alberti, era utilizar uma proporção que fosse mais agradável entre as amplitudes e alturas, reduzindo a simetria à sinfonia e a harmonia do som a uma espécie de harmonia à vista. Para Alberti, a música e a geometria têm algo em comum; a música é geometria traduzida para o som e, na música, as mesmas harmonias são sons audíveis que informam a geometria do edifício.

Segundo Wittkower (1958) e Scholfied (1958), Alberti foi o arquiteto renascentista que mais aplicou a escala pitagórica no desenho de suas obras, restringindo os comprimentos, larguras e alturas de seus quartos às razões geométricas relacionadas à antiga escala grega, mostradas no Quadro 1.

Quadro 1- Razões geométricas relacionadas ao intervalo musical usadas por Alberti

\begin{tabular}{|l|l|}
\hline Razão & Intervalo musical \\
\hline $1: 1$ & Uníssono \\
\hline $4: 3$ & Quarto (diatessarão) \\
\hline $3: 2$ & Quinto (diapente) \\
\hline $16: 9$ & - \\
\hline $2: 1$ & Oitava (diapasão) \\
\hline
\end{tabular}

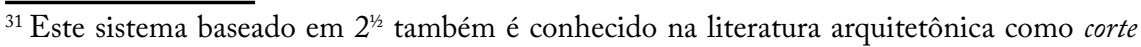
sagrado, e foi fundamentado na pesquisa de Carol e Donald Watts, que descobriram seu uso no projeto da arquitetura doméstica de Pompéia, Herculano e Óstia. Watts e Watts (1987) afirmam que o uso da fórmula pelo arquiteto romano representa uma "declaração filosófica" sobre a quadratura do círculo.
} 


\begin{tabular}{|l|l|}
\hline Razão & Intervalo musical \\
\hline $9: 4$ & - \\
\hline $8: 3$ & Décimo primeiro (quarto acima da oitava) \\
\hline $3: 1$ & Décima segunda (quinta acima da oitava) \\
\hline $4: 1$ & Décima Quinta (próxima oitava) \\
\hline
\end{tabular}

Fonte: (KAPPRAFF, 2001, p. 12)

De acordo com Jâmblico (1988), devido à interação com o monocórdio e influenciado pelo misticismo dos números naturais, especialmente os quatro primeiros (tetraktys), Pitágoras descobriu as progressões aritméticas, geométricas e harmônicas.

Alberti tinha experimentado que cordas com comprimentos de razões 1:2 (os extremos 1 e 2), 2:3 (média harmônica de 1 e 2), e 3:4 (média aritmética de 1 e 2) produziam combinações agradáveis de sons e construíam uma escala dessas proporções.

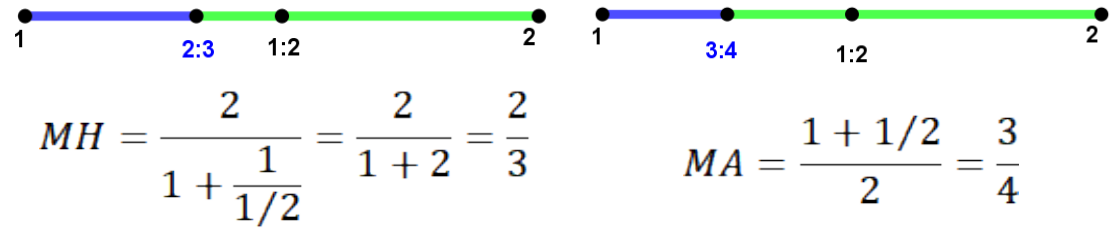

As três médias formam uma progressão geométrica (mais adiante voltaremos a essa questão), mas o que aconteceu com a média geométrica entre 1 e $1 / 2$ ? Note que a média geométrica entre eles é $1: \sqrt{2}$, que corresponde exatamente ao Fá sustenido da escala cromática ${ }^{32}$.

Como $\sqrt{2}$ é um número irracional, e por essa época não era aceito pela escola pitagórica, utilizaram-se ciclos de quintas em lugar do irracional, e quando passavam à oitava, multiplicavam por 2 a longitude da corda, para voltar à oitava original.

Dentro da filosofia pitagórica, as proporções tinham uma origem mística, e é Platão quem nos descreve que estão relacionadas por um sistema comum:

\footnotetext{
${ }^{32}$ Para conhecer mais sobre a teoria musical, ver <https://eltamiz.com/elcedazo/2013/02/17/ musica-y-ciencia-10-desmenuzando-la-tonalidad/>. Acesso em 8 mar. 2018.
} 
Daí que o deus, quando começou a constituir o corpo do mundo, o tenha feito a partir de fogo e de terra. Todavia, não é possível que somente duas coisas sejam compostas de forma bela sem uma terceira, pois é necessário gerar entre ambas um elo que as una. $\mathrm{O}$ mais belo dos elos será aquele que faça a melhor união entre si mesmo e aquilo a que se liga, o que é, por natureza, alcançado da forma mais bela através da proporção... Foi por isso que, tendo colocado a água e o ar entre o fogo e a terra, e, na medida do possível, produzido entre eles a mesma proporção, de modo a que o fogo estivesse para o ar como o ar estava para a água, e o ar estivesse para a água como a água estava para a terra, o deus uniu estes elementos e constituiu um céu visível e tangível. Foi por causa disto e a partir destes elementos - elementos esses que são em número de quatro - que o corpo do mundo foi engendrado, posto em concordância através de uma proporção (PLATÃO, 2011, p. 100).

Do anterior, encontramos que a constituição do corpo do mundo está baseada em quatro elementos: fogo, ar, água, terra. E, interpretando as palavras de Platão, teríamos a proporção múltipla:

$$
\frac{\text { fogo }}{\text { ar }}=\frac{a r}{\text { água }}=\frac{\text { água }}{\text { terra }}
$$

Temos que $a, b, c$, e $d$ formam uma série geométrica sobre si $\cdots=\frac{a}{b}=\frac{b}{c}=\frac{c}{d}=\cdots$, onde os pontos indicam que a série pode ser continuada em ambas as direções.

Platão encontrou harmonia nos quadrados e cubos das proporções duplo e triplo, partindo da unidade, assim que, para os números 2 (feminino) e 3 (masculino), ambos primos, para $a=1$ e $b=2$; e para o caso $a=1$ e $b=3$ geram duas sequências $\{1,2,4,8 \ldots\}$ e $\{1,3,9,27 \ldots\}$, representadas com a forma de uma lambda em trabalhos anteriores ao Platão. 
A harmonia do mundo se expressa nos sete números 1, 2, 3, 4, 8, 9, 27, que contêm a secreta Eurythmia do macrocosmo e microcosmo pelo igual. De fato, os quocientes entre esses números não só contêm todas as consonâncias musicais, senão também a música inaudível dos céus e a estrutura da alma humana (PLATÃO, 2011).

De lambda, temos obtido duas séries geométricas relacionadas com a escala musical de Alberti, a da esquerda está baseada no diapasão (2:1). A outra está formada pelas médias aritméticas de cada par sucessivo, restrito apenas a valores inteiros:

$\begin{array}{rrrrrr}1 & 2 & 4 & 8 & 16 & 32 \ldots . \\ & & 3 & 6 & 12 & 24 \ldots\end{array}$

Observe que, embora cada número da segunda série seja a média aritmética dos dois números que a sustentam na série superior, cada número da série superior é a média harmônica do par de números que a sustenta a partir de baixo. Além disso, cada série corta o outro na proporção 3: 2 e 4: 3 (o quinto e quarto musical). Isso pode ser continuado de novo e de novo para formar séries geométricas sem fim, na razão 2: 1 da esquerda para a direita, 3: 2 ao longo da diagonal esquerda, e 4: 3 ao longo da diagonal inclinada à direita envolvendo apenas inteiros:

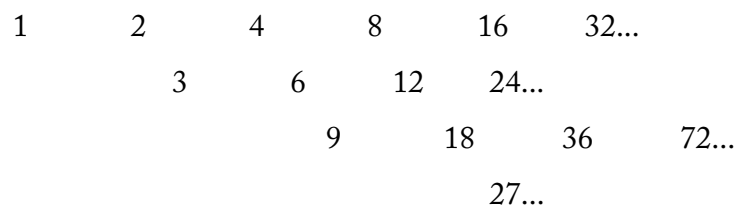

Assim é formado o lambda de Platão pelo limite dessas séries geométricas.

Alberti (1582) estabelece as relações entre os intervalos musicais e a geração de certos módulos, onde se constituem três planos: Planos curtos: unidade (1:1), sesquialtera/quinta diapente (2:3), sesquitertia/quarta diatessarão (3:4). Planos médios: dupla unidade/oitava diapasão (1:2), sesquialtera dobrada/diapente diapente (4:6:9), sesquitertia dobrada/diatessarão diates- 
sarão (9:12:16). Planos longos: dupla sesquialtera /tripla unidade diapasão diapente (3:6:9), dupla sesquitertia /diapasão diatessarão (3:6:8).

Seguidores de Alberti, como Andreas Palladio (1508-1580), basearam sua arquitetura em uma revisão da escala pitagórica, que foi obra do astrônomo Cláudio Ptolomeu (90-168). Assim mesmo, foi Palladio quem teve influência até meados do XVIII, definindo sete formas básicas (Figura 4), com as quais seria montado o tecido espacial do edifício (ALMEIDA, 2005).

Figura 4 - Figuras básicas e proporções trabalhadas por Palladio

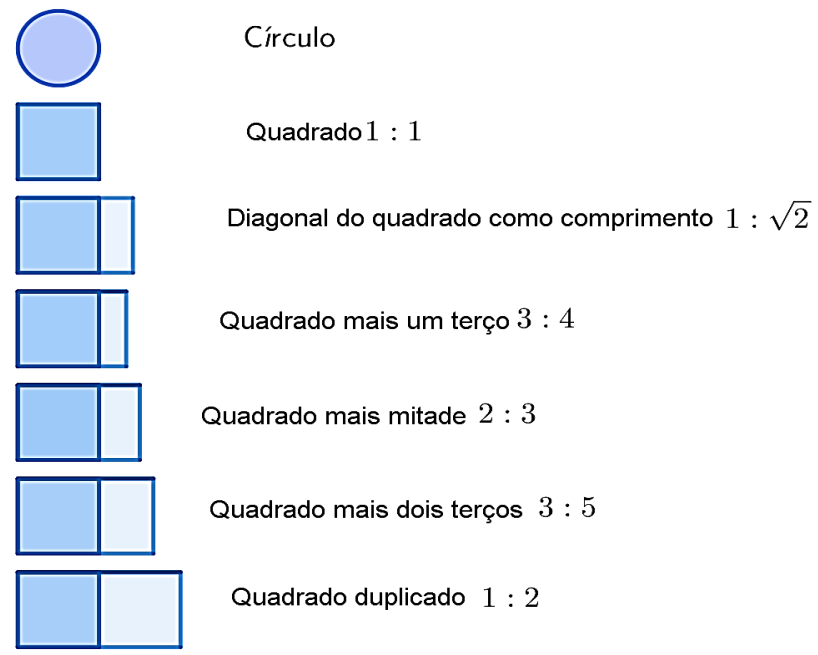

Fonte: Elaborada pela autora

Palladio usou três conjuntos diferentes de proporções para o desenho de suas vilas e igrejas na Itália. Segundo Conway e Roenisch (2006), eles foram baseados nas proporções aritméticas, geométricas e harmônicas, e determinaram a relação entre a altura dos quartos, sua largura e comprimento e os tamanhos relativos de diferentes salas. Conway e Roenisch (2006) descrevem quais seriam essas proporções, assim como oferecem um exemplo com cada uma delas.

$\mathrm{Na}$ proporção aritmética, o tamanho de um quarto poderia ser baseado na relação entre os números 3:6:9. Isso é aritmética, desde que 
$9-6=3$ e $6-3=3$. Assim, um quarto que mede 6 pés por 12 pés, com uma altura de 9 pés, proporciona-se aritmeticamente.

$\mathrm{Na}$ proporção geométrica, o primeiro termo relaciona-se com o segundo, como o segundo o faz com o terceiro. Assim, a relação entre os números 4:6:9 é geométrica porque sua proporção geométrica é 2:3. Nós poderíamos, então, ter um quarto medindo 4 pés por 9 pés com uma altura de 6 pés, porque a largura do quarto é dois terços da altura, e a altura é dois terços do comprimento.

Na proporção harmônica, a relação entre 6:8:12 está na diferença proporcional entre o número maior e menor em cada par: 8-6=2, que é um terço de $6 ; 12-8=4$ que, por sua vez, é um terço de 12 . Assim, a proporção de um terço liga a largura (6), comprimento (12) e altura (8) de um quarto.

\section{Proporção áurea na arquitetura}

A arquitetura do Renascimento derivava da medida dos seres humanos e era precisamente sua projeção externa, cuja caraterística provém do legado vitruviano. De acordo com Vitrúvio, os escultores gregos estudaram em profundidade as proporções do corpo humano, esculpindo suas obras de acordo com uma proporção exata que os arquitetos empregaram em templos e monumentos; essa proporção também é chamada proporção de ouro, proporção divina, seção áurea ou dourada.

No entanto, temos a esclarecer que, nos tratados de arquitetura da época, a seção áurea foi apresentada de maneira implícita. Para Vitrúvio:

O umbigo é o ponto central natural do corpo humano. De fato, se um homem é colocado com a cara para cima, com suas mãos e seus pés esticados, colocando o centro do compasso em seu umbigo e desenhando uma circunferência, esta tocaria as pontas das duas mãos e dos dedos dos pés. (1997, p.82, tradução nossa) ${ }^{33}$.

\footnotetext{
${ }^{33}$ Texto original: "E1 ombligo es el punto central natural del cuerpo humano. En efecto, si se coloca un hombre boca arriba, con sus manos y sus pies estirados, situando el centro del compás en su ombligo y trazando una circunferencia, ésta tocaría la punta de ambas manos y los dedos de los pies". (VITRÚVIO, 1997, p. 82)
} 
Dessa descrição, encontramos O Homem Vitruviano ${ }^{34}$ de Leonardo Da Vinci (1452-1519), no qual ele estabeleceu uma conexão entre os lineamentos da figura humana e a geometria. Como resultado, o desenho renascentista está caracterizado pela experimentação com formas ideais, geometrias ideais e proporções ideais.

A obra arquitetônica de Da Vinci é pouca, em um nível prático, mas extensa e elaborada nos níveis teóricos. Um exemplo disso são os esboços encontrados no Codex de Ashburnham, onde existem desenhos de planta e elevação de igrejas circulares, incluindo uma com um espaço interior rodeado por oito naves, sete delas idênticas e outra onde a entrada seria encontrada, uma varanda e nove cúpulas, oito pequenas para cada um dos navios e uma maior no espaço central.

Passando a um período mais moderno, encontramos outro exemplo de estrutura que utiliza a proporção áurea: as janelas na Unité d'Habitation, na Marselha de 1947. A obra, elaborada pelo arquiteto Charles-Édouard Jeanneret-Gris (1887-1965), conhecido como Le Corbusier, mostra vários tipos de formações, aparecendo o mesmo princípio de estrutura, dividido de acordo com a proporção áurea, ou seja, contemplando o sistema modular ou o módulo de ouro (LEOPOLD, 2005).

De acordo com Yilmaz (1999), dentro da arquitetura encontram-se diferentes representações geométricas ${ }^{35}$ que são chave para a elaboração de desenhos e estão associadas à proporção áurea (ver Figura 5). Na Figura 5 b), o retângulo CDEF se conhece como o retângulo de ouro, e a Figura 5 d) é conhecida como a espiral do retângulo de ouro.

\footnotetext{
${ }^{34}$ Esse desenho acompanhava as notas feitas pelo artista por volta do ano 1490 num dos seus diários. Atualmente se encontra na Accademia di Belle Arti de Veneza.

${ }^{35}$ A Seção de Ouro é derivada de construções geométricas simples, feitas com o compasso e a régua.
} 
Figura 5 - Geração da seção áurea através de operações geométricas

a)

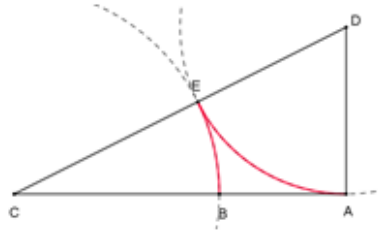

b)

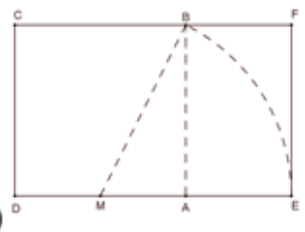

c)

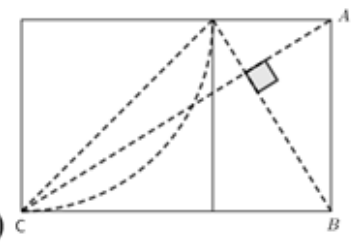

d)

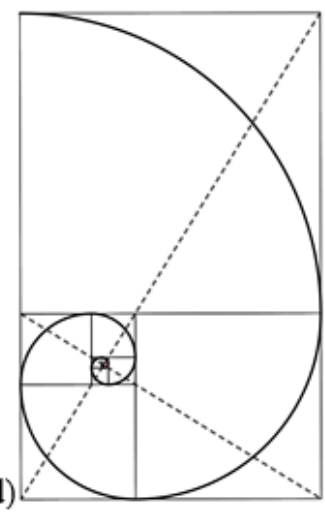

e)
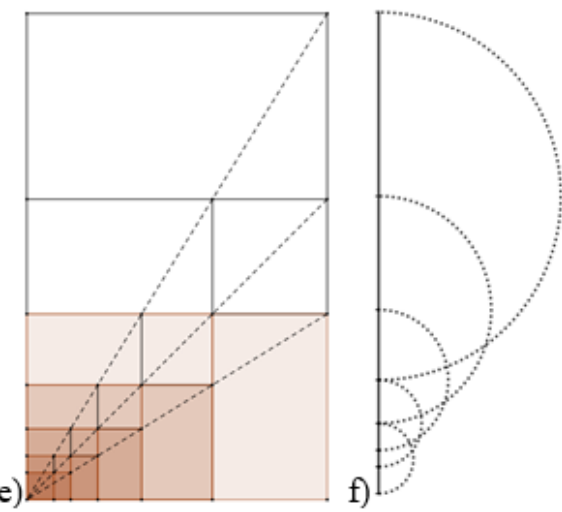

Fonte: Elaborado pela autora

De acordo com um estudo elaborado pelo arqueólogo norueguês Frederik Macody Lund (1863-1943), ao fazer a comparação entre as plantas de várias catedrais góticas europeias, nelas se encontravam dois elementos constantes: o quadrado duplo e a seção áurea (LUND, 1921). Do mesmo modo, também são encontrados em várias estruturas arquitetônicas que, inclusive, foram criadas em períodos anteriores à escola pitagórica (por exemplo, Stonehenge, a pirâmide de Quéops), que contêm a proporção áurea.

Uma propriedade importante dos retângulos áureos é que, quando se justapõem da forma mostrada na Figura 6, a diagonal AD passa pelo vértice $\mathrm{G}$. 
Figura 6 - Retângulos áureos

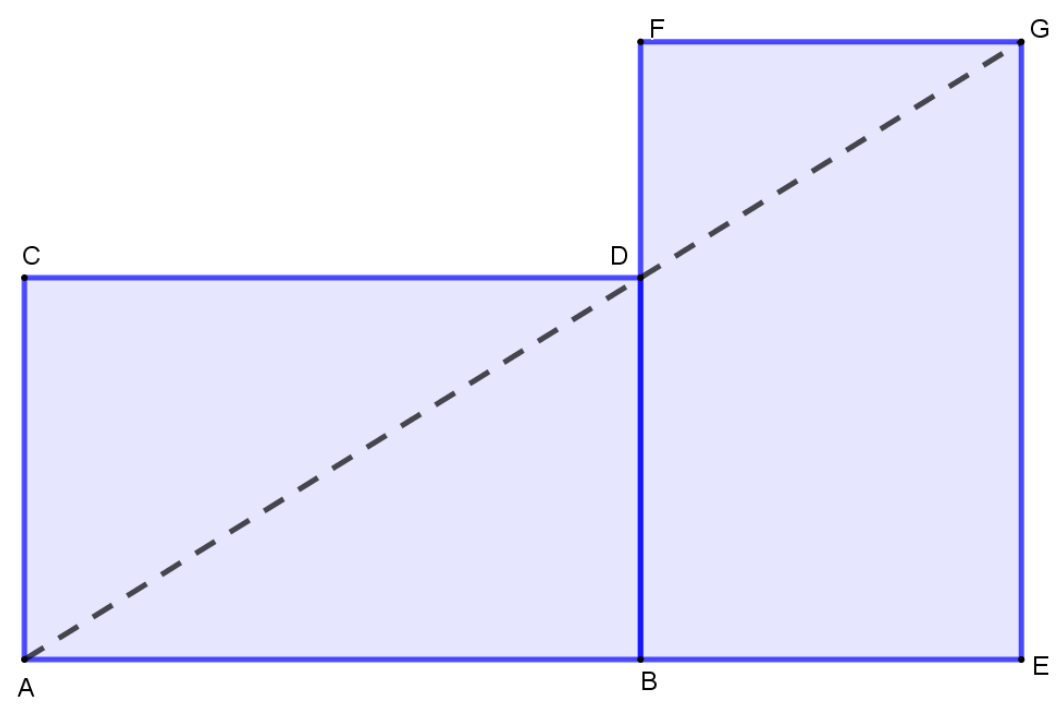

Fonte: Elaborado pela autora.

Precisamente, se a construção de um novo retângulo de ouro é repetida com o retângulo cuja diagonal é AG, e assim por diante, a Figura 5 e) é construída (ver Figura 7). Tente experimentar fazê-lo!

Figura 7 - Construção de retângulos de ouro simultâneos

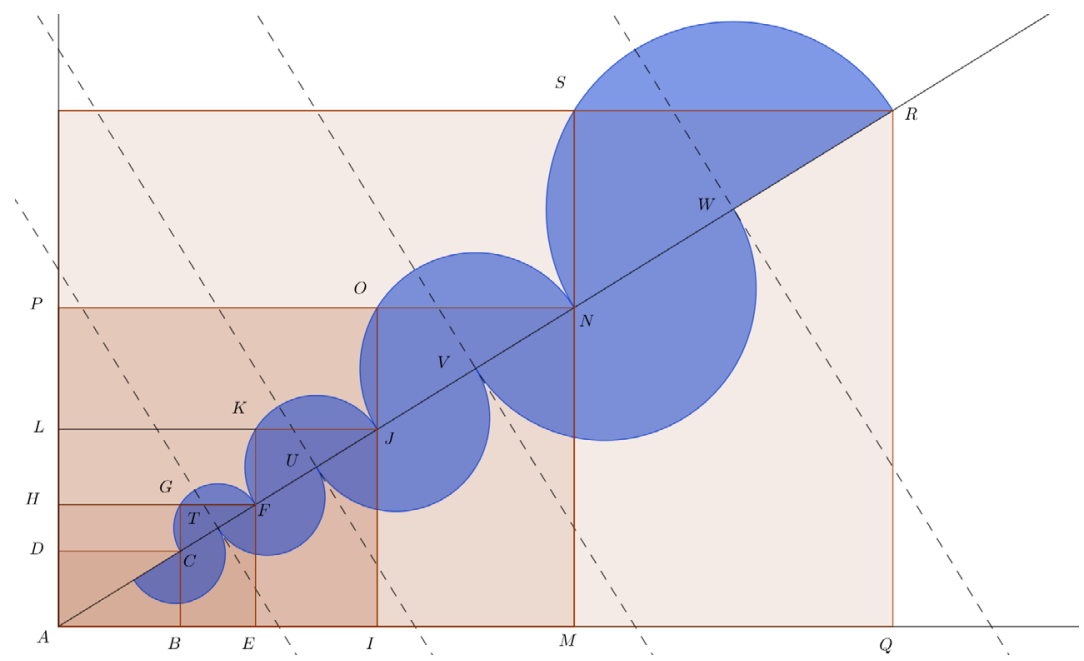

Fonte: Elaborado pela autora. 


\section{Tentando construir nossos arcos antigos}

Para conhecer um pouco mais do que fizeram os arquitetos em tempos antigos e saber qual foi a geometria que utilizaram para decorar belos templos, poderíamos nos acercar da matemática, e convidar os nossos estudantes a cultivar a criatividade, apoiada da arquitetura antiga e moderna.

A ideia desta seção não é dar um curso de desenho gráfico, mas vislumbrar a ferramenta que se encontra nessas construções para ligá-las com as salas de aula de matemática. No livro de Narciso Sánchez (2011), encontramos a geometria dos arcos, a guia para sua construção e o traçado de vários arcos utilizados na arquitetura, durante diferentes épocas, na Espanha. Assim, apresentaremos a continuação com 3 arcos, para que o leitor mergulhe um pouco no mundo da arquitetura. Vale a pena esclarecer que os passos para realizar essa construção foram tomados de Sánchez (2011), mas as imagens foram elaboradas pela autora, utilizando o software Geogebra.

\section{Arco Romano ou de ponto médio}

Esse arco também é conhecido como formarete. É um arco de um único centro localizado na linha de partidas, no eixo de simetria. É o arco mais simples. Sua localização (ver Figura 8) deve ser levada em consideração, para evitar o inconveniente causado pela luz excessiva.

Figura 8 - Construção de arco romano
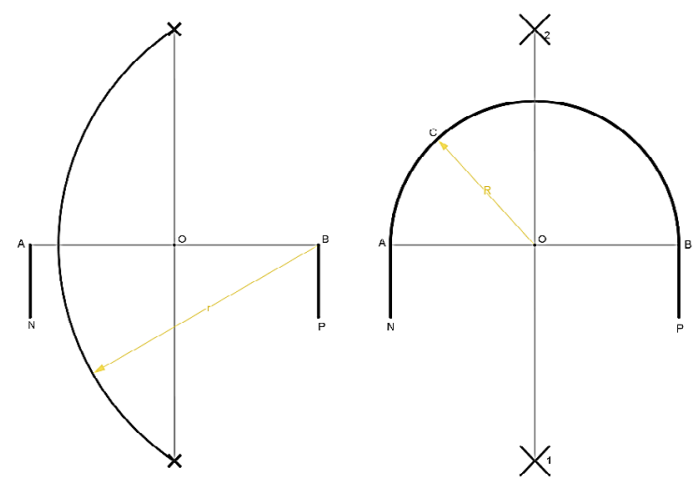

Fonte: Elaborado pela autora 
Procedimento de traçado:

Sejam $A$ e $B$ os começos. Determinamos a mediatriz do segmento $A B$, para o que traçamos, com centro em $B$, um arco de raio $r$ maior que o ponto médio de $A B$. Repetimos o processo tomando a medida anterior, desde o ponto $A$, obtendo os pontos 1 e 2 que, ao juntá-los, nos dá o ponto $O$ no segmento $A B$. Com centro em $O$ e raio $O A$, traçamos um arco desde $A$ até $B$, obtendo o arco buscado.

Arco Canopial (conopial) equilateral ou flamigero

O arco canopial é muito baixo e com um entalhe no centro da chave, o que o torna semelhante a um pavilhão ou cortina. De aparência islâmica, o arco canopial (ver Figura 9) foi amplamente utilizado durante os séculos XIV e XV na arquitetura gótica tardia ${ }^{36}$. Esse tipo de arquitetura também foi conhecido como gótico flamejante, e do manuelino e, às vezes, é mostrado com pequenos elementos de decoração em sua parte mais alta.

Figura 9 - Construção de arco canopial equilateral

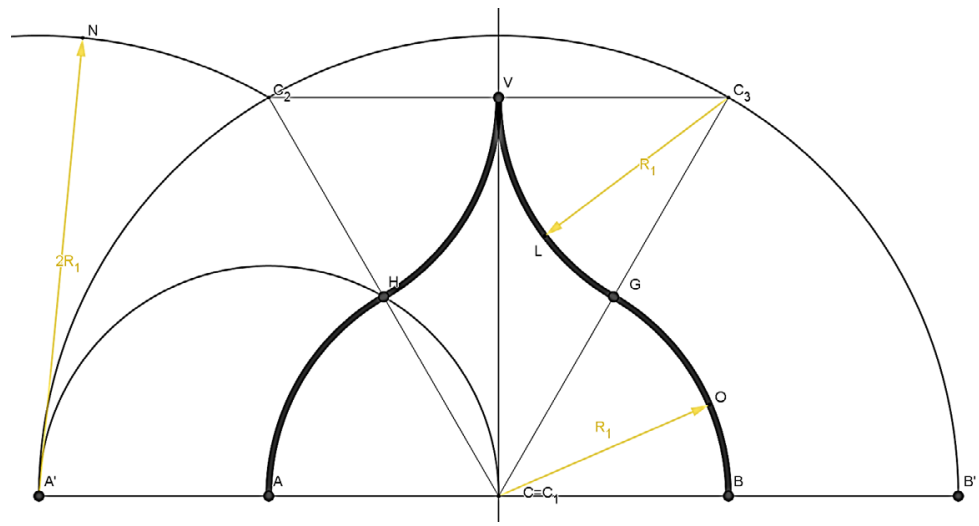

Fonte: Elaborado pela autora.

${ }^{36}$ Ver CONWAY e ROENISCH (2006). 
Sejam $A$ e $B$ os pontos iniciais. Traça-se $C$, ponto de interseção da mediatriz do segmento $A B$ com ele. Tomando a medida $A C$, traça-se uma circunferência com centro em $A$ e raio $A C$, obtendo o ponto $A$ '. Com centro em $C$ e raio $C A^{\prime}\left(2 R_{1}\right)$, traçamos uma semicircunferência sobre a qual traçamos um triângulo equilátero com vértice no ponto $C$. Os lados desse triângulo constituem os raios do arco. Com centro em $C$ e raio $R_{1}=C A$ (ou raio $R_{1}=C B$ ), traçamos as seções inferiores do arco canopial. Com o centro nos pontos $C_{2}$ e $C_{3}$, extremos da base do triângulo equilátero, desenhamos os arcos superiores (com raio $R_{1}$ ). Os centros $C_{2}$ e $C_{3}$ estão localizados sobre linhas verticais que partem dos pontos iniciais do arco $(A$ e $B)$.

\section{Gola com calcanhar invertido comprimido}

A Gola é um molde composto por dois arcos que formam uma espécie de "S" (ver Figura 10). Geralmente está localizado no capitel, embora, como qualquer outro, possa ser encontrado no porão ${ }^{37}$.

Figura 10 - Construção de gola com calcanhar invertido comprimido

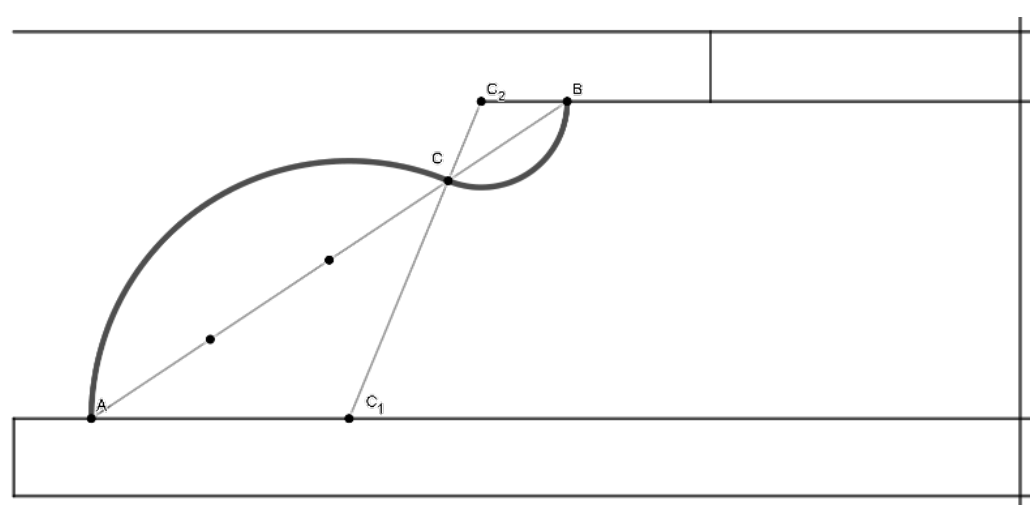

Fonte: Elaborado pela autora

\footnotetext{
${ }^{37}$ Segundo Pinhal (1996), o capitel refere-se à parte superior, em geral esculpida, de uma coluna; e o porão, ao pequeno espaço situado entre o solo e o primeiro pavimento de uma casa.
} 


\section{Procedimento de traçado:}

Está situado no basamento. Para a sua construção juntamos os pontos $A$ e $B$ através de uma linha. Nós dividimos essa linha em quatro partes iguais. Traçamos a mediatriz do segmento $B C$ que corta o prolongamento horizontal do listel superior, obtendo o ponto $C_{2}$. A junção do ponto $C$ com o $C_{2}$, em sua prolongação com a linha de partida, nos determina o ponto $C_{1}$. Para a construção do calcanhar invertido comprimido traçamos os arcos correspondentes com centros em $C_{1}$ e $C_{2}$.

Estimado professor, essas três construções foram tomadas de um livro por uma licença Creative Commons License Deed-Reconocimiento-No comercial 3.0 España, o que significa que, com esse tipo de licença, você é livre para compartilhar, copiar, alterar ou criar e redistribuir o material em qualquer meio ou formato, dando crédito corretamente aos autores, indicando se foram feitas alterações e sem fazer uso do material com fins comerciais. Portanto, você pode usá-lo sem problema na sala de aula de matemática. Igualmente existem livros e sites online gratuitos que você encontrou ao longo da leitura e que pode consultar para a questão que propomos no presente capítulo, e aproximar-se aos conhecimentos matemáticos desenvolvidos pelos pitagóricos através da arquitetura.

\section{Considerações finais}

Tendo-nos debruçados sobre as várias das noções matemáticas que a escola de Pitágoras desenvolveu, e, em seguida, devido à sua expansão pelo mundo ocidental, após a sua fusão com platonismo, vemos como suas ideias influenciaram a Arquitetura. A proporção, conforme estipulada por Vitrúvio, foi a chave para respeitar a tríade solidez-utilidade-beleza, bem como a base para procurar a perfeição em estruturas arquitetônicas.

Vitrúvio era um homem culto e experiente que contribuiu para a arquitetura e para as gerações posteriores, tomando as ferramentas básicas que foram transmitidas oralmente antes de seu período e as registrando, assim como consignando seus conhecimentos obtidos em seu labor como 
arquiteto. No entanto, não se trata apenas do Tratado de Vitrúvio; encontramos mais tarde outros arquitetos que expandiram o conhecimento nessa ciência e fizeram suas próprias contribuições, ou com base nos elementos de vitruviano, ou fazendo comentários e dando-lhes novos elementos.

Embora a arquitetura esteja baseada na geometria para seus desenhos, e outras áreas de matemática para o seu desenvolvimento, é interessante ver como De Architecture não tinha imagens em seus livros, fato que poderia gerar muita dificuldade em interpretar as indicações ou definições nele expostas. Mesmo assim, os posteriores tratados foram sendo publicados até se tornarem livros com maiores e melhores indicações para as novas gerações ${ }^{38}$.

Para o leitor que tem conhecimento em arquitetura, este capítulo pode ter poucos arquitetos citados, ou poucas estruturas dos diferentes períodos arquitetônicos mencionados; porém, a ideia é convidar o leitor, alfabetizado em arquitetura ou não, a conhecer e aprofundar sobre as noções da escola pitagórica (teorema de Pitágoras, tetraktys, proporções, raiz quadrada, proporção áurea) usadas por arquitetos ao longo da História e entender que a arquitetura evoluiu em sua concepção de beleza e harmonia. Ao mesmo tempo, convidamos o professor de matemática a utilizar a história da arquitetura para introduzir diferentes objetos matemáticos mencionados no presente capítulo.

\section{Referências}

ALBERTI, L. Los diez libros de Architectura. Tradução de Francisco Lozano. Madrid: [s.n.], 1582.

ALMEIDA, F. À luz da cadência. A música na arquitetura. 2005. 94f. Trabalho de Conclusão do Curso (Graduação em Arquitetura e Urbanismo) - Departamento de Arquitetura e Urbanismo, Centro de Artes e Comunicação, Universidade Federal de Pernambuco, Recife, 2005.

BENDINELLI, G. I1 Mausoleo Sotterrano. Altrimenti detto. Basilica di porta Maggiore. Roma: Accademia Nazionale del Lincei, 1923. Disponível em: <http://www.tpsalomonreinach.mom.fr/Reinach/MOM_TP_072989/MOM_TP_072989_0001/PDF/ MOM_TP_072989_0001.pdf>. Acesso em: 21 dez. 2017.

\footnotetext{
${ }^{38}$ Por exemplo, La Archittetura de Sérlio; I quattro libri dell'architettura de Palladio, De re aedificatoria de Alberti etc.
} 
BURKERT, W. Lore and Science in Ancient Pythagoreanism. Tradução de Edwin Minar. Massachusetts: Harvard University Press, 1972.

COLE, E. Grammaire de l'Architecture. Paris: Dessain \& Tolra, 2003.

CONWAY, H.; ROENISCH, R. Understanding Architecture. An introduction to architecture and architectural history. London: Taylor \& Francis e-Library, 2006.

FORNARI, F; GATTI, E. Brevi notizie relative alla scoperta di un monumento sotterraneo presso Porta Maggiore. Notizie degli scavi, Roma, p. 30-52, 1918.

GONZÁLEZ, P. M. El teorema llamado de Pitágoras. Una historia geométrica de 4000 años. SIGMA, Vitoria, v. Azaroa, n. 32, p. 103-130, 2008. Disponível em: <http://www. hezkuntza.ejgv.euskadi.eus/r43-573/es/contenidos/informacion/dia 6_sigma/essigma/adjuntos/sigma_32/8_pitagoras.pdf >. Acesso em: 17 fev. 2018.

HOLLOWAY, R. Architettura sacra e matematica pitagorica a Paestum. La Parola del Passato, n. 21, p. 60-64, 1966.

HÖCKER, C. Brill's New Pauly: Spacing, interaxial, 2006. Disponível em: <http://dx.doi. org/10.1163/1574-9347_bnp_e525750>. Acesso em: 30 out. 2018.

JÂMBLICO. The Theology of Arithmetic. Tradução de Robin Waterfield. Michigan: Phanes Press, 1988. p. 37-38.

JOOST-GAUGIER, C. The Iconography of Sacred Space: A Suggested Reading of the Meaning of the Roman Pantheon. Artibus et Historiae, Cracóvia, v. 19, n. 38, p. 21-42, 1998. Disponível em: <http://www.jstor.org/stable/1483585. >. Acesso em: 2 fev. 2018.

KAPPRAFF, J. Connections. The geometric bridge between art and science. 2. ed. Singapur: World Scientific Publishing Co. Pte. Ltd., 2001.

KENNY, B. P. Pythagoras, the Tetraktys and the Masonic Compasses and Square. Oracle Lodge, Dublin, v. November, n. 8, 2004. Disponível em: <http://137.43.115.45/oracle/ downloads/docs/C_S_Tetraktys.pdf>. Acesso em: 11 dez. 2017.

KUILMAN, M. Quadralectic Architecture: A Survey of Tetradic Testimonials in Architecture. Amsterdam: Falcon Press, 2011.

LAERCIO, D. Los diez libros de Diógenes Laercio. Tomo II. Tradução de Josef Ortiz Sanz. Madrid: Imprenta Real, 1972.

LEHMANN, K. The Dome of Heaven. The Art Bulletin, New York, v. 27, n. 1, p. 1-27, 1945.

LEOPOLD, C. Experiments on Relations between Geometry, Architecture and Music. Journal for Geometry and Graphics, v. 9, n. 2, p. 169-176, 2005. Acesso em: 11 fev. 2018. 
LUND, F. M. Ad Quadratum; A Study of the Geometrical Bases of Classic \& Medieval Religious Architecture, with Special Reference to Their Application in the Restoration of the Cathedral of Nidaros. London: B.T. Batsford, 1921.

NABERS, N.; WILTSHIRE, S. The Athena Temple at paestum and pythagorean theory. Greek, Roman and Byzantine Studies, Tennessee, v. 21, n. 3, p. 207-215, 1980.

NICÔMACO. Introduction to arithmetic. Tradução de Martin D’Ooge. New York: The Macmillan Company, 1926.

PLATÃO. Timeu-Crítias. Tradução de Rodolfo Lopes. Coimbra: Centro de Estudos Clássicos e Humanísticos, 2011.

PINHAL, P. Colégio de Arquitetos, 1996. Disponível em < http://www.colegiodearquitetos.com.br/dicionario/>. Acesso: 10 set. 2018

PONT, G. The Cinema as Secular Temple: Ethos, Form and Symbolism of the Capitol Theatre. Nexus Network Journal, Newtown, v. 5, n. 2, p. 73-99, 2003. ISSN 1522-4600. Disponível em: <https://link.springer.com/content/pdf/10.1007\%2Fs00004-003-0018-8. pdf>. Acesso em: 11 dez. 2017.

PORFIRIO. Vida de Pitágoras. Argonáuticas órficas. Himnos órficos. Tradução de Emilio Fernández-Galiano. Madrid: Editorial Gredos, 1987.

RASKIN, E. Architecture and people. New Jersey: Prentice-Hall, 1974.

ROTH, L. Entender la arquitectura: Sus elementos, historia y significado. Tradução de Carlos Saénz de Valicourt. Barcelona: Editorial Gustavo Gili, 1999.

SAITO, F. História da matemática e suas (re)construções contextuais. São Paulo: Editora Livraria da Física, 2015.

SÁNCHEZ, N. Geometría de los arcos. Guía para la construcción y trazado de arcos. Murcia: Región de Murcia. Consejería de Educación, Formación y Empleo, 2011. Disponível em: <http://bibliotecadigital.educarm.es/bidimur/i18n/catalogo_imagenes/grupo. cmd?path=1000233>. Acesso em: 20 mar. 2018.

SANTOS, M. Teorema de Pitágoras: suas diversas demonstrações. 2010. 31 f. Trabalho de Conclusão do Curso (Especialização em Educação Matemática para professores do Ensino Médio) - Departamento de Matemática, Universidade Estadual da Paraíba, Campina Grande, 2010.

SCHMELING, G. A Pythagorean Element of the Subterranean Basilica at the Porta Maggiore. Journal Latomus, v. 28, n. 4, p. 1071-1073, 1969.

SCHOLFIED, P. H. The Theory of Proportion in Architecture. New York: Cambridge University Press, 1958. 
SOREN, D.; SOREN, N. A Roman Villa and a Late-Roman Infant Cemetery: Excavation at Poggio Gramignano, Lugnano in Teverina. Rome: "L'Erma" di Bretschneider, 1999.

VITRÚVIO. Los diez libros de Arquitectura. Tradução de José Luis Oliver Domingo. Madrid: Alianza Editorial, S. A., 1997.

WATTS, C.; WATTS, D. Geometrical Ordering of the Garden Houses at Ostia.Journal of the_Society of Architectural Historians, Berkeley, v. 46, n. 3, p. 265-276, 1987.

WITTKOWER, R. La arquitectura en la edad del Humanismo. Argentina: Nueva Visión, 1958.

YILMAZ, S. Evolution of the Architectural Form Based on Geometrical Concepts. 1999. 110f. Dissertação (Mestrado de Arquitetura) - Departamento de Arquitetura, Instituto de Tecnologia de Ízmir, Ízmir, 1999. 


\section{UMA DIVINA PROPORÇÃO PARA OS PITAGÓRICOS}

Renata Caterine Gambaro Cleto da Silva

\section{Introdução}

Os Pitagóricos acreditavam que existiam relações entre a natureza e os números. Desde então, temos o costume de olhar a natureza e procurar relações dela com a matemática. $\mathrm{Na}$ Bíblia, encontramos tal visão, já que ali observamos o seguinte dizer: "mas tudo dispuseste com medida, número e peso" (Sb.11,20).

Segundo Pacioli (1509), Aristóteles (384 a.C.- 322 a.C) acreditava que as matemáticas são fundamentos para chegar ao conhecimento de qualquer ciência, pois elas estão no primeiro grau de certeza. Para Pacioli (1509), todas as artilharias foram fabricadas com a força dos números, medidas e suas proporções. Ele observou ainda que, embora tivesse caído ao fim, Arquimedes conseguiu defender, por muito tempo, a cidade de Siracusa do exército romano, por conta de suas invenções que foram fruto de estudos matemáticos.

Para o autor, os romanos, em todas suas outras conquistas, foram vitoriosos e expandiram seus territórios, pois, "preparavam engenheiros e outros especialistas de terra e de mar, cuja suficiência não teria sido possível sem as disciplinas matemáticas, ou seja, Aritmética, Geometria e Proporções”. (PACIOLI, 1509, p.8).

Para Platão (428 a.C.- 347 a.C.), Aristóteles, Boécio (524 a.C.- 480 a.C.) e Isidoro (636 a.C.- 560 a. C.), as matemáticas eram compostas por Aritmética, Geometria, Astronomia e Música e outras que dependiam dessas. Porém, Pacioli (1509) as reduz a apenas três ou então a cinco, pois, ou se considerava apenas Aritmética, Geometria e Astronomia - e as outras lhes seriam subalternas - ou, utilizando-se a ideia de Platão, seria incluída a Música; então, seriam Aritmética, Geometria, Astronomia, Música e Perspectiva, uma vez que, se a Música agrada aos ouvidos, a Perspectiva agrada a visão e, para ele, a visão é a primeira porta pela qual o intelecto entende e aprecia. 
Mas, para Platão, na Geometria encontravam-se ocultas todas as outras matemáticas, e ele negava o acesso de pessoas, em seu ginásio, que não detinham tal conhecimento (PACIOLI, 1509).

Para Kepler (1571-1630), "A geometria possui dois grandes tesouros: um é o teorema de Pitágoras; o outro a divisão de uma linha em extrema e média razões. $\mathrm{O}$ primeiro, podemos comparar a uma medida de ouro; ao segundo, podemos chamar de joia preciosa”. (HUNTLEY, 1985, p.35).

Desse modo, pretendemos analisar, neste capítulo, conceitos teóricos de razão áurea e perceber as suas relações e desenvolvimento ao longo da História, bem como trazer o que autores afirmaram a seu respeito e como elas se relacionam com as ideias pitagóricas.

\section{Razão Áurea: construção de um conceito}

A razão áurea sempre despertou curiosidade em seus estudiosos, uma vez que eles conseguiam encontrar a sua razão em elementos do mundo, como na arquitetura, na arte, no corpo humano e na música. Alguns deles são: o Parthenon (440-430 a.C), as pirâmides de Quéops (2560 a.C) no Egito, as obras de Leonardo da Vinci (1452-1519), a sequência de Fibonacci (1170-1250), a Catedral de Notre Dame (1163-1345), e as construções no livro Timeu e Crítias, de Platão (360 a.C.).

Porém, Markowsky (1992) está convencido de que algumas das relações encontradas, ao longo da História, entre a razão áurea e o mundo são falsas e, segundo o autor, "muito do que é apresentado sobre a razão áurea na arte, arquitetura, literatura e estética é falso ou seriamente enganoso" (MARKOWSKY, 1992, p.2, tradução nossa ${ }^{1}$ ).

Historicamente, a razão áurea tomou diversas denominações dadas por diversos autores, filósofos, arquitetos e matemáticos. É conhecida também por número de ouro, divina proporção, proporção áurea, golden ratio, extrema e média razão e número phi $(\phi)$. Atualmente, a razão áurea é um número irracional relacionado ao phi $(\phi)$, e acredita-se que os Pitagóricos já pensavam na incomensurabilidade do número.

\footnotetext{
${ }^{1}$ Much of what is presented about it in art, architecture, literature, and esthetics is false or seriously misleading.
} 
Markwosky (1992) afirma que muitos acreditam que os termos "razão áurea" e "seção áurea" vêm desde a antiguidade. Porém, o termo "seção áurea" apareceu no tempo de Leonardo da Vinci, e utilizar o adjetivo áureo e o número phi é relativamente moderno, já que a razão áurea passou a ser denotada pela letra grega $\phi$ apenas no início do século XX, pelo matemático Mark Barr² (1871-1950), pois era a inicial do nome Phidias (480 a.C- 430 a.C), um famoso escultor grego, que fazia uso dessa razão em seus trabalhos. Também Queiroz (2007) afirma que a denominação pela letra grega $\phi$ foi feita no início do século XXI em homenagem ao arquiteto e escultor Phidias, que foi o responsável pelo templo grego Parthenon.

Já Euclides (300 a.C), em “Os Elementos”, no livro VI, a respeito de extrema e média razão, define que: "uma reta é dita estar cortada em extrema e média razão, quando como a toda esteja para o maior segmento, assim o maior para o menor" (EUCLIDES, 300 a.C., p.263).

Analisemos como cortar uma reta em extrema e média razão, utilizando a demonstração de Euclides. Para isso, é necessário observar que Euclides faz uso de um vocabulário próprio para suas demonstrações. Desse modo, ao longo da demonstração, apresentaremos comentários em notas de rodapé para que o leitor entenda o que significam alguns termos, podendo observar, na Figura 1, como os segmentos são chamados durante as demonstrações.

Figura 1- Extrema e Média Razão

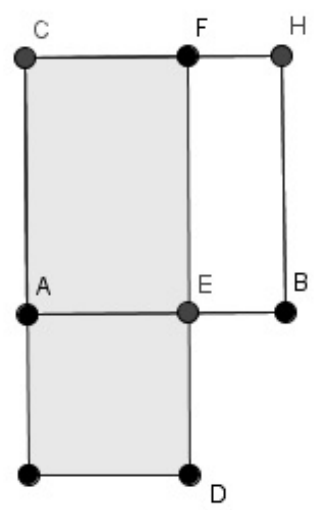

Fonte: Elaborado pela autora

${ }^{2}$ James Mark McGinnis Barr 
Assim,

Seja a reta finita ${ }^{3} \mathrm{AB}$; é preciso, então, cortar a reta $\mathrm{AB}$ em extrema e média razão.

Fique descrito sob $\mathrm{AB}$ o quadrado $\mathrm{BC}^{4}$, e fique aplicado ${ }^{5}$ à $\mathrm{AC}$ o paralelogramo $\mathrm{CD}$ igual ao $\mathrm{BC}$, excedente pela figura $\mathrm{AD}$, semelhante ${ }^{6}$ ao $\mathrm{BC}^{7}$.

Mas o $\mathrm{BC}$ é um quadrado; portanto, também a $\mathrm{AD}$ é um quadrado. $\mathrm{E}$, como o $\mathrm{BC}$ é igual ao $\mathrm{CD}$, fique subtraído o $\mathrm{CE}^{8}$ comum; portanto, o $\mathrm{BF}^{9}$ restante é igual à $\mathrm{AD}$ restante. Mas também é equiângulo com ela. ${ }^{10}$ Portanto, os lados, à volta dos ângulos iguais, dos $\mathrm{BF}, \mathrm{AD}$ são inversamente proporcionais; portanto, como $\mathrm{FE}$ está para a $\mathrm{ED}$, assim a $\mathrm{AE}$ para a $\mathrm{EB}$. Mas, por um lado, a FE é igual à $\mathrm{AB}$, e, por outro lado, a $\mathrm{ED}$, à $\mathrm{AE}$. Portanto, como a $\mathrm{BA}$ está para a $\mathrm{AE}$, assim a $\mathrm{AE}$ para a $\mathrm{EB}$. Mas a $\mathrm{AB}$ é maior do que a $\mathrm{AE}$; portanto, também a $\mathrm{AE}$ é maior do que a EB.

Portanto, a reta $\mathrm{AB}$ foi cortada em extrema e média razão no $\mathrm{E}$, e o maior segmento dela é o AE; o que era preciso fazer. (EUCLIDES, 300 a. C. p.263)

Note que, se considerarmos $\mathrm{AB}=\mathrm{x}$ e $\mathrm{AE}=\mathrm{y}$, como $\mathrm{AB}=\mathrm{AC}=\mathrm{HB}=\mathrm{CH}=\mathrm{FE}, \quad$ pois $\quad \mathrm{BC}$ é quadrado, logo,

\footnotetext{
${ }^{3}$ Quando Euclides usa o termo reta finita, ele está se referindo ao que conhecemos como segmento de reta.

${ }^{4}$ Euclides refere-se aos paralelogramos pelas suas diagonais, desse modo o quadrado $\mathrm{ABHC}$, o qual tem por diagonal $\mathrm{BC}$.

${ }^{5}$ Para esse passo veja proposição 29 de Os Elementos, página 262.

${ }^{6}$ Semelhante para Euclides é a propriedade da figura; no caso, $\mathrm{AD}$ deverá ser um quadrado já que BC é um quadrado.

${ }^{7} \mathrm{Na}$ proposição 29 , do livro VI, Euclides demonstra como " $\grave{A}$ reta dada aplicar, igual à retilinea dada, um paralelogramo excedente por uma figura paralelogrâmica semelhante à dada." (EUCLIDES, 300 a. C. p.262)

${ }^{8} \mathrm{O}$ paralelogramo ACFE

${ }^{9} \mathrm{O}$ paralelogramo $\mathrm{BHFE}$

${ }^{10}$ Proposição 23, do Livro VI de Os Elementos de Euclides ele diz que "Os paralelogramos equiângulos têm entre si a razão composta das dos lados.” (EUCLIDES, 300 a. C. p.256)
} 
$\mathrm{AB}=\mathrm{AC}=\mathrm{HB}=\mathrm{CH}=\mathrm{FE}=\mathrm{x}$. Pelo mesmo motivo, $\mathrm{AE}=\mathrm{ED}=\mathrm{y}$. Ainda observe que $\mathrm{EB}=\mathrm{AB}-\mathrm{AE}$, então, $\mathrm{EB}=\mathrm{x}-\mathrm{y}$.

Segundo Euclides, temos que E é o ponto em que corta o segmento $\mathrm{AB}$ em extrema e média razão, dado que: $\frac{B A}{A E}=\frac{A E}{E B}$.

Desse modo, $\frac{x}{y}=\frac{y}{x-y}$, o que implica que: $x(x-y)=y^{2}$

Logo, $x^{2}-x y=y^{2}$.

Observe que $A E=y=\sqrt{x(x-y)}$, que é a média geométrica dos segmentos $A B$ e $E B$.

Logo, $A E=\sqrt{A B \cdot E B}$.

Ainda observe que, se tomarmos $A B=x=1$, temos que $1-y=y^{2}$, ou seja, temos uma equação de segundo grau que facilmente podemos resolver e encontrar o valor do segmento $A E=y$, o valor numérico do número $\varphi$.

Assim, $y^{2}+y-1=0 \rightarrow y=\frac{-1 \pm \sqrt{1^{2}-4 \cdot(1) \cdot(-1)}}{2.1} \rightarrow y=\frac{-1 \pm \sqrt{5}}{2}$

Como trabalhamos com medidas de segmentos, e um segmento não tem medida negativa, logo desprezamos o valor $y=\frac{-(1+\sqrt{5})}{2}$, visto ser um valor negativo; então, temos, como valor numérico para o número $\phi$, o valor $y=\frac{\sqrt{5}-1}{2}$

Porém, hoje em dia, normalmente utilizamos a construção do segmento áureo por desenho geométrico, de modo diferente do que Euclides propôs. Para tal construção, tomemos um segmento $\mathrm{AB}$, como mostrado na Figura 2 abaixo.

\section{Figura 2}

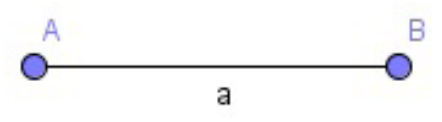

Fonte: Elaborado pela autora 
Traçamos BD como a medida de metade do segmento de $\mathrm{AB}\left(\frac{A B}{2}\right)$, de modo que $\mathrm{BD}$ seja perpendicular à reta $\mathrm{AB}$, como na Figura 3.

\section{Figura 3}

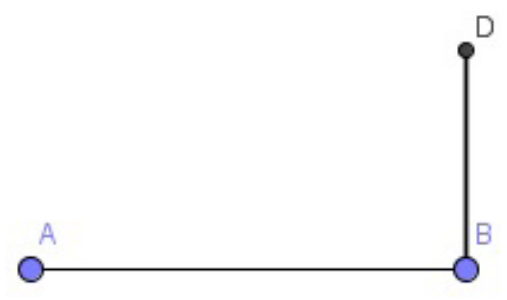

Fonte: Elaborado pela autora

Traçamos AD. Então, com centro em $\mathrm{D}$ e raio $\mathrm{DB}$ traçamos um arco cortando DA em E, como na Figura 4.

\section{Figura 4}

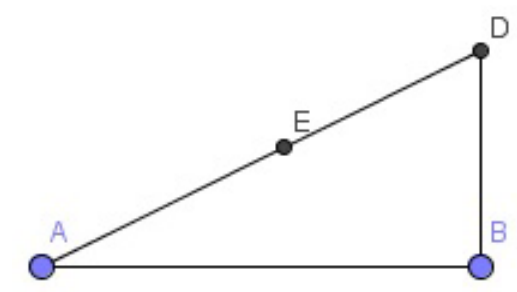

Fonte: Elaborado pela autora

Com centro em $\mathrm{A}$ e raio $\mathrm{AE}$ traçamos um arco cortando $\mathrm{AB}$ em $\mathrm{C}$ como na Figura 5.

\section{Figura 5}

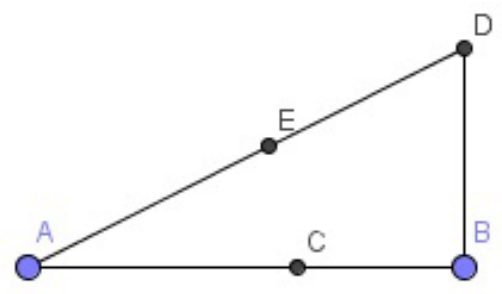

Fonte: Elaborado pela autora 
Desse modo, $\mathrm{AC}$ é o segmento áureo de $\mathrm{AB}$.

Então note que $D B=\frac{A B}{2}$, e como o ângulo $A B D$ é reto, logo estamos nas condições do Teorema de Pitágoras; desse modo, $(A B)^{2}+(D B)^{2}=(A D)^{2}$, mas observe que $A D=A E+E D$, e $E D=D B=\frac{A B}{2}$

$$
\begin{aligned}
& \text { Portando, }(A B)^{2}+\left(\frac{A B}{2}\right)^{2}=\left(A E+\frac{A B}{2}\right)^{2} \\
& \rightarrow A E+\frac{A B}{2}=\sqrt{\frac{4 A B^{2}+A B^{2}}{4}}=\frac{A B \sqrt{5}}{2} \\
& \rightarrow A E=\frac{A B \sqrt{5}}{2}-\frac{A B}{2} \\
& \text { Logo, } A E=\frac{A B(\sqrt{5}-1)}{2}
\end{aligned}
$$

E como $A E=A C$, então $A C$ é o segmento áureo de $A B$.

Luca Pacioli11 ${ }^{11}$ (155-1517) chamava a razão áurea de "divina proporção", assim como Kepler, pois, para Pacioli (1509), a razão áurea era uma manifestação de Deus, e ele encontrou algumas semelhanças para justificar esse pensamento. Dentre elas, ele acreditava que as quatro afirmações a seguir são suficientes: a primeira afirmação é que "ela é somente uma e não mais e, não é possível atribuir-lhe outras espécies, nem diferenças. $\mathrm{E}$ esta unidade é o supremo epíteto de Deus, segundo toda escola teológica e também filosófica" (PACIOLI, 1509, p.12).

A segunda corresponde à Santíssima Trindade, como in Divinis, em que existe uma mesma substância em Pai, Filho e Espírito Santo, da mesma forma uma proporção desse tipo pode ser encontrada em três termos. A terceira correspondência é que, como Deus, "não se pode definir, nem por nós pode ser entendido por palavras, da mesma maneira, esta proporção não pode ser determinada por um número inteligível,

\footnotetext{
${ }^{11}$ Luca Pacioli utiliza, como fontes teóricas, Os Elementos de Euclides, O Timeu de Platão, as Obras de Vitrúvio, as ideias dos neoplatônicos florentinos e outras obras da Idade Média para escrever seu livro publicado em 1509, De Divina Proportione.
} 
nem ser expressa por quantidade racional, sendo sempre oculta e secreta" (PACIOLI, 1509, p.12). A quarta é de que, assim como Deus não pode mudar, "é tudo em tudo, e está em tudo em toda parte" (PACIOLI, 1509, p.12), da mesma maneira a proporção, em toda quantidade "é a mesma e sempre invariável" (PACIOLI, 1509, p.12).

Ainda pensando no misticismo envolvendo as matemáticas, Pacioli (1509) utiliza-se do pensamento Platônico, de que cada elemento da natureza correspondia a um poliedro regular. Assim, o fogo correspondia ao tetraedro, a terra ao hexaedro, o ar ao octaedro, a água ao icosaedro, e a quinta essência ao dodecaedro; e esse último não pode ser formado sem a razão áurea. Desse modo, ele compara a necessidade de se utilizar a razão áurea para formar esse poliedro, $\operatorname{com}[\mathrm{o}]$ a necessidade de Deus para criar o universo. Ainda observa, em seu livro, que todos os quatro poliedros podem ser inscritos no dodecaedro, afirmando a esse fato "que Platão atribui ao Dodecaedro a correspondência com o universo" (PACIOLI, 1509, p.16).

Segundo Almeida (2001), Proclus (412-485) atribuiu a Pitágoras a descoberta da teoria dos irracionais e também afirmou ter ele descoberto a teoria, colocando junto das figuras cósmicas, que se acreditava serem os sólidos platônicos, "na mesma sentença em que atribui a Pitágoras a descoberta da teoria dos irracionais (ou proporções), também afirma que ele descobriu colocando-o junto das figuras cósmicas" (ALMEIDA, 2001, p.55). Para Almeida (2001), Platão deve ter copiado a forma do "colocando junto" dos pitagóricos, uma vez que ela se encontra no Timeu e Crítias.

Miguel (1993), por sua vez, nos mostra que historiadores acreditaram, ora que a incomensurabilidade surgiu dos estudos do pentagrama, ora que surgiu da diagonal de um quadrado; já os defensores, como Kurt von Fritz (1945), de que a "descoberta de segmentos incomensuráveis [deve] ter ocorrido através da comparação entre o lado e a diagonal de um pentágono" (MIGUEL, 1993, p. 200), criticam o surgimento do irracional pela diagonal do quadrado, pois dizem que a demonstração contém "sentenças pequenas e concisas que não têm paralelo na literatura grega do $\mathrm{V}$ século $\mathrm{a}$. C.”(MIGUEL, 1993, p. 202). 
Boyer (1974) comenta, também, que a demonstração exige um alto grau de abstração, em que é questionável a possibilidade da descoberta da incomensurabilidade pela diagonal do quadrado. Porém, ambos os estudos acreditam que esse conceito era de conhecimento dos Pitagóricos.

Já segundo Huntley (1985), a apreciação pelos “mistérios” levou os gregos antigos a atribuírem ao dodecaedro um significado especial, pois suas doze facetas regulares correspondiam aos doze signos do zodíaco, assim considerado um símbolo do Universo. Além do mais, os Pitagóricos observaram que a medida de um dos lados do dodecaedro e o raio da circunferência que circunscreve esse dodecaedro estão na razão áurea, como na Figura 6.

Desse modo, $\frac{r}{l}=\phi$.

\section{Figura 6}

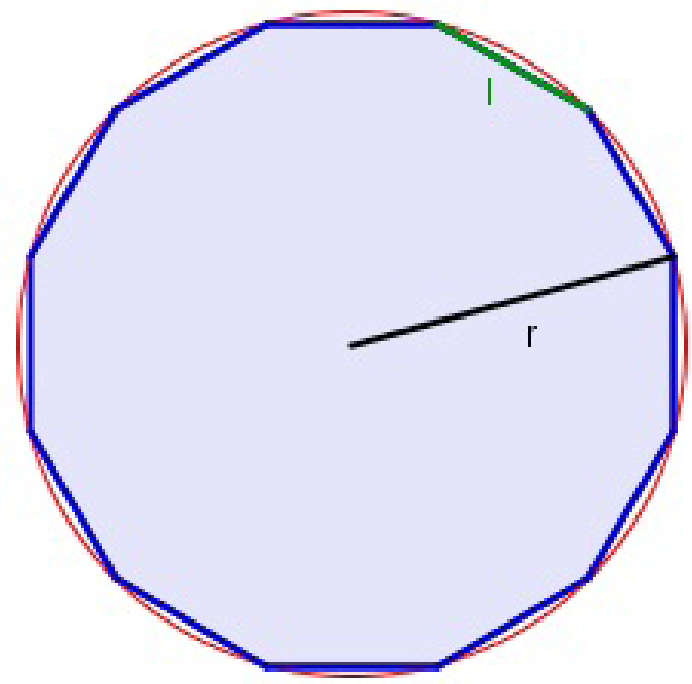

Fonte: Elaborado pela autora

Para a sociedade pitagórica, o pentagrama era considerado símbolo da boa saúde. Alguns autores citam que esse seria o símbolo da sociedade pitagórica, como Lucianus (120-185), para quem "o triplo triângulo entrelaçado, o pentagrama, i.e., a estrela pentágono, foi usado pelos pitagóricos como símbolo para reconhecimento entre os membros desta escola, e era por eles chamados de boa saúde" (ALMEIDA, 2001 p. 58). 
Porém, ainda há dúvidas sobre o fato de ele ser o símbolo da sociedade pitagórica. Existe até uma lenda sobre isto que diz: certa vez, um pitagórico estava viajando e se adoentou; um homem, vendo sua situação frágil, acolheu-o em sua casa e cuidou dele até sua morte. O homem que estava acamado, no entanto, antes de falecer, pediu que o senhor que estava cuidando dele fizesse tal símbolo em sua porta, que seus companheiros o recompensariam pelos cuidados prestados quando o vissem.

$\mathrm{Na}$ construção do pentagrama, que alguns autores acreditam ser o símbolo da sociedade pitagórica, é possível observar a existência da razão áurea, e os Pitagóricos tinham tal conhecimento, por isso, a grande curiosidade e fascinação. Para isso, veja a Figura 7 a seguir, onde temos um pentágono regular, circunscrito em uma circunferência $C_{1}$ de raio $\mathrm{R}$.

\section{Figura 7}

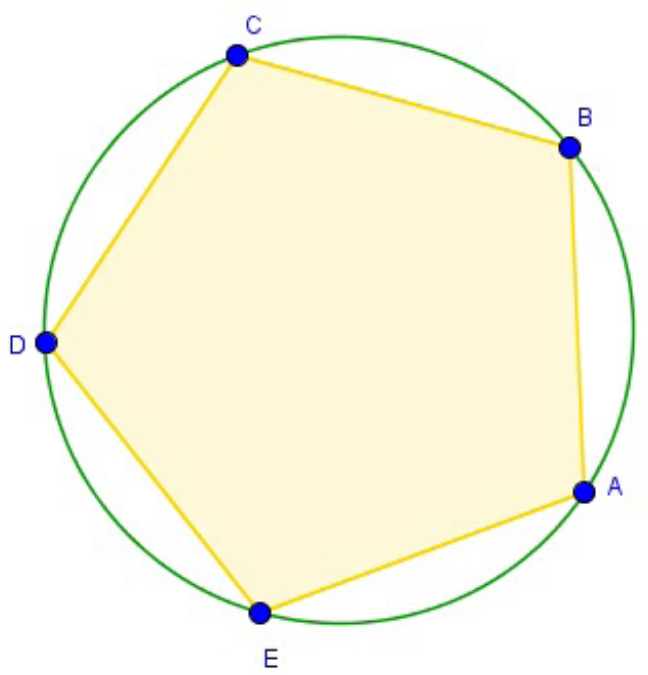

Fonte: Elaborado pela autora

Observe, na Figura 8, que, se traçarmos segmentos de retas, ligando os vértices do pentágono, teremos um pentagrama. Desse modo, traçamos $A C, A D, B D, B E$ e $C E$. 


\section{Figura 8}

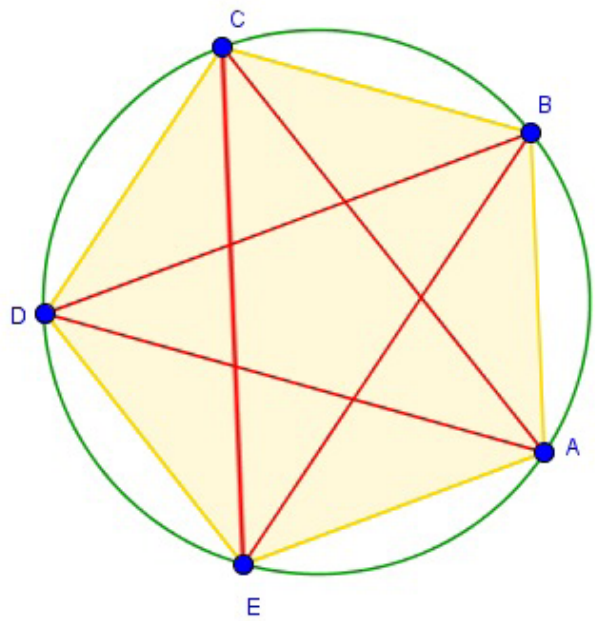

Fonte: Elaborado pela autora

Note que, na Figura 9, a interseção de $A C \operatorname{com} B D$ resulta no ponto $B^{\prime}$, e esse ponto corta o segmento $A C$ em extrema e média razão. Do mesmo modo, a interseção do segmento $C E \operatorname{com} B D$ resulta no ponto $C^{\prime}$, que corta o segmento $C E$ em extrema e média razão, e assim os pontos $A^{\prime}, D^{\prime}$ e $E^{\prime}$ com as mesmas propriedades.

\section{Figura 9}

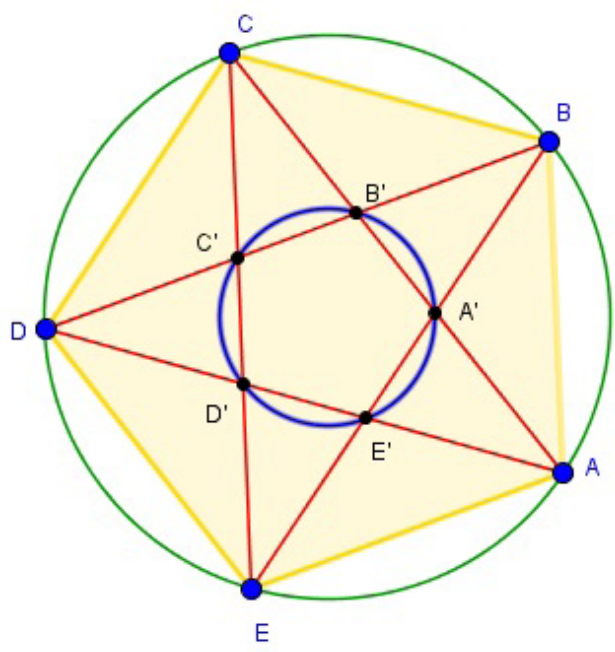

Fonte: Elaborado pela autora 
Além do pentagrama em que aparece o número de ouro, a sequência de Fibonacci é um dos conceitos, na qual ele também aparece. Leonardo de Pisa (1170-1250), nascido na cidade de Pisa, foi um matemático italiano e, segundo Santos (2013), o nome Fibonacci foi dado pelo historiador Guillaume Libri, em uma nota de rodapé, no livro Histoire des Sciences Mathématique em Italie (1838). Para Santos (2013), a sua obra Liber Abacci, publicada em 1202, continha um grande conhecimento sobre teoria de números e da álgebra até sua época. Para ele, foi uma obra importante, no que se refere à introdução do sistema de numeração indo-arábico na Europa e ao desenvolvimento da álgebra e aritmética no mundo ocidental. No livro, existe um problema conhecido como problema dos coelhos de Fibonacci, sendo apresentado da seguinte forma:

Um homem pôs um par de coelhos num lugar cercado por todos os lados por um muro. Quantos pares de coelhos podem ser gerados a partir desse par em um ano se, suspostamente, todo mês cada par dá a luz um novo par, que é fértil a partir do segundo mês? (SANTOS, 2013, p.30)

Fibonacci apresenta a resolução de que no mês um há apenas um casal, no mês dois, ainda existe aquele casal apenas. No mês três há o casal inicial acrescido de um casal de filhotes, ou seja, dois casais, no mês quatro há o casal inicial, o casal de filhotes do mês anterior e mais um casal de filhotes, portanto três casais. No mês cinco, existem os três casais do mês anterior mais dois casais de filhotes, totalizando cinco casais.

Observamos que o número de casais em cada mês é igual ao número de casais do mês anterior mais os filhotes que nasceram no mês em questão. Consequentemente, ao final de 12 meses, haverá 144 casais.

Os valores de casais, de cada mês em sequência, formam o que conhecemos como a sequência de Fibonacci, 1,1,2,3,5,8,13,21,34,55,89,14 4.... Assim, consideremos $F_{n}$ a sequência, onde $n \in \mathbb{N}$.

Observe que essa sequência é uma sequência de recorrência, visto que cada termo é definido como função de termos anteriores. Segundo Santos (2013), Leonard Euler (1707 -1783) e Abraham de Moivre (16671754) encontraram relações importantes entre a sequência de Fibonacci e o número $\phi$, que mais tarde foi estudada pelo matemático francês Jacques 
Phillipe Marie Binet (1786-1856) e ficou conhecida como fórmula de Binet, para a sequência Fibonacci. Porém, podemos observar que, a partir do $5^{\circ}$ termo da sequência de Fibonacci, ao dividirmos o termo em questão com seu antecessor obteremos números próximos ao valor do número $\phi$. Assim:

$$
\begin{aligned}
& \frac{5}{3}=1,6666666 \ldots \\
& \frac{8}{5}=1,6 \\
& \frac{13}{8}=1,625 \\
& \frac{21}{13}=1,6153846 \ldots \\
& \frac{34}{21}=1,6190476 \ldots \\
& \frac{55}{34}=1,6176470 \ldots \\
& \frac{89}{55}=1,6181818 \ldots
\end{aligned}
$$

Notemos que, ora esse valor fica maior que o número $\phi$, ora esse valor fica menor que o número $\phi$, considerando 1,6180340 como o número $\phi$, contando apenas até a sétima casa decimal. Mas observamos que as razões entre os termos $\boldsymbol{a}_{\boldsymbol{n}+\mathbf{1}}$ e $\boldsymbol{a}_{\boldsymbol{n}}$ são aproximadas ao $\phi$. De acordo com Huntley (1985), qualquer sequência de inteiros em que a lei de formação seja "cada termo é a soma dos dois termos anteriores, quaisquer que sejam os dois primeiros termos" (HUNTLEY, 1985, p.55), ou seja, $\boldsymbol{a}_{\boldsymbol{n}+\mathbf{1}}=\boldsymbol{a}_{\boldsymbol{n}}+\boldsymbol{a}_{\boldsymbol{n}-\mathbf{1}}$, a razão de termos sucessivos da sequência irá aproximar-se do número $\phi$, Em outras palavras: $\frac{a_{n+1}}{a_{n}} \cong \phi$

Não se sabe se Fibonacci tinha conhecimento dessa relação entre as razões dos termos sucessivos de sua sequência e o número $\phi$, ou se isso é um estudo recente da sequência. Markwosky (1992), por exemplo, aponta que, em algumas obras, como o Parthenon e as obras de Leonardo da Vinci, consideram-se algumas partes da obra e se excluem outras, para que os objetos pareçam estar em razão áurea. 
O Parthenon, construído aproximadamente no século $\mathrm{V}$ a.C, em uma montanha no centro da cidade de Atenas, chamada Acrópolis, era um templo, para homenagear a deusa Atena. Apesar da ação do tempo, de conflitos e da poluição, ainda se encontra preservado, e é objeto de afirmações acerca da razão áurea, que muitos autores afirmam existir em sua estrutura.

Markwosky (1992), no entanto, tece críticas, pois autores de textos matemáticos não se incomodam em afirmar que o Parthenon está contido em um retângulo de ouro, mesmo que, para fazer tal afirmação, desconsiderem partes do monumento, e algumas delas ficam fora do retângulo. "Embora incorpore muitos equilíbrios geométricos, seus construtores no século $\mathrm{V}$ a.C. provavelmente não tinham conhecimento consciente da razão de ouro". (MARKWOSKY, 1992, p. 9, tradução nossa) ${ }^{12}$.

Ainda, as dimensões do Parthenon variam de fonte para fonte, já que existem diferentes autores medindo diferentes pontos. Porém, segundo Markwosky (1992), apesar de muitos estudiosos tentarem encontrar a razão áurea nas estruturas do Parthenon, essa busca não deveria ser feita, já que, naquela época na Grécia antiga, a arquitetura era um método empírico, em que a experiência e a intuição tinham papel importante.

Com base em um pequeno número de textos antigos, foi feito um esforço para encontrar (em edifícios suficientemente bem preservados) um sistema coerente de proporções baseado no número de ouro, pi $(\pi)$, ou nas proporções universais dos Pitagóricos. Quase sempre, quando todas as medidas possíveis foram tomadas, algum sistema de figuras geométricas ou algum denominador comum modular apareceu. No entanto, a validade dessa pesquisa permanece incerta: é fácil superestimar a importância de uma especulação arquitetônica. Não é improvável que alguns arquitetos, na imitação de esculturas como Polycleitos, desejem basear seus trabalhos em um sistema rígido de índices, mas seria errado generalizar. No ambiente conservador da Grécia antiga, a atividade

\footnotetext{
${ }^{12}$ Though it incorporates many geometric balances, its builders in the fifth century B.C. probably had no conscious knowledge of the golden ratio.
} 
arquitetônica foi uma prática empírica em que a experiência e a intuição, ou seja, o "conhecimento profundo" desempenhou um papel importante (MARKWOSKY, 1992, p. 9, tradução nossa). ${ }^{13}$

Além disso, muitos autores afirmaram que Leonardo da Vinci usou a proporção áurea abundantemente em suas obras, porém, o entusiasmo dos autores ao fazer tal afirmação se deve ao próprio Pacioli, que afirma ter feito o convite para Leonardo Da Vinci ilustrar seu livro De Divina Proportione. Entretanto, segundo Markwosky (1992), não há nenhuma indicação de que Leonardo da Vinci tenha utilizado a razão áurea em suas biografias, como as de Leonardo Da Vinci de Clark, Vallentin Vall e Zammattio e outros.

Markwosky (1992) vai além, ao afirmar que vemos muitos padrões geométricos na natureza, arte, arquitetura, nos objetos diários, e que $\mathrm{Da}$ Vinci procurou proporções para uma figura nesse padrão geométrico.

Ao olhar, vemos muitos padrões geométricos na natureza, arte, arquitetura e até mesmo em coisas mundanas como mesas, cadeiras e copos e pires. Um padrão muito especial que encontramos nas folhas em torno das hastes de plantas, em conchas marinhas e no arranjo de sementes de girassol é chamado de seção áurea. Leonardo da Vinci, um dos maiores gênios de todos os tempos, procurou proporções para a figura ideal em termos desse padrão geométrico. (MARKWOSKY, 1992, p.10, tradução nossa) $)^{14}$.

\footnotetext{
${ }^{13}$ On the basis of a small number of ancient texts, an effort has been made to find (in buildings sufficiently well preserved) a coherent system of proportions based on the golden number, pi $(\pi)$, or on the universal ratios of the Pythagoreans. Almost always, when all possible measurements have been taken, some system of geometric figures or some modular common denominator has come to light. However, the validity of this research remains uncertain: it is easy to overestimate the importance of an architectural speculation. It is not unlikely that some architects, in imitation of sculptures such as Polycleitos, should have wished to base their works on a strict system of ratios, but it would be wrong to generalize. In the conservative environment of ancient Greece, architectural activity was an empirical practice in which experience and intuition, that is to say 'mastery', played a large part.

${ }^{14}$ As we look about us, we see many geometric patterns in nature, art, architecture, and even in such mundane things as tables, chairs, and cups and saucers. A very special pattern that we find in leaves around the stems of plants, in seashells, and in the arrangement of Sunflower seeds is called the golden section. Leonardo da Vinci, one of the greatest geniuses of all times, stated proportions for the ideal figure in terms of this geometric pattern.
} 
Uma obra de Leonardo da Vinci, utilizada para sustentar a afirmação de que suas obras utilizam a razão áurea, é a pintura de São Jerônimo de 1483, em que se apresenta o acadêmico com um leão a seus pés. Alguns especialistas acreditam que Da Vinci projetou a figura nas proporções áureas, uma vez que um retângulo contorna a figura. "Essa abordagem teria sido compatível com o ardente interesse do artista em matemática. Ele sentia especial deleite no que descreveu uma vez como 'recreações geométricas'. (MARKWOSKY, 1992, p.11, tradução nossa) ${ }^{15}$

A figura ${ }^{16}$ de St. Jerome, de Leonardo Da Vinci, nos mostra as falhas nas afirmações sobre essa pintura; é certo, porém, que as pinturas de Leonardo Da Vinci, como o Homem Vitruviano, contêm a razão áurea, visto que foi criada nessas proporções para agregar ao livro de Pacioli.

[...] é suficiente para mostrar as falhas nas reivindicações sobre esta pintura. A colocação do retângulo é um pouco arbitrária, pois o topo não toca a cabeça. $O$ retângulo é desenhado usando uma linha muito grossa. Seu lado esquerdo é tangente a uma pequena dobra de tecido e não toca o corpo de São Jerônimo em nenhum ponto. $\mathrm{O}$ braço direito de São Jerônimo se estende bem além do lado esquerdo do retângulo sobreposto. Finalmente, o conhecimento de Leonardo da Vinci com a proporção divina data de seu encontro com Luca Pacioli, que ocorreu 13 anos depois de pintar São Jerônimo. (MARKWOSKY, 1992, p.12, tradução nossa) ${ }^{17}$

\footnotetext{
15 Such an approach would have been in keeping with the artist's ardent interest in mathematics. He took Special delight in what he once described as 'geometrical recreations'.

${ }_{16}$ Observar figura em Markwosy, 1992, p.11. Disponível em: < https://www.goldennumber. net/wp-content/uploads/George-Markowsky-Golden-Ratio-Misconceptions-MAA.pdf>

${ }^{17}[\ldots]$ is sufficient to show the flaws in the claims about this painting. The placement of the rectangle is somewhat arbitrary since the top does not touch the head. The rectangle is drawn using a very thick line. Its left side is tangent to a small fold of fabric and does not touch St. Jerome's body at any point. St. Jerome's right arm extends well past the left side of the superimposed rectangle. Finally, Leonardo da Vinci's acquaintance with the divine proportion dates from his meeting with Luca Pacioli, which occurred 13 years after he painted St. Jerome.
} 


\section{Considerações Finais}

Observamos que as relações existentes da razão áurea e o Parthenon, a sequência de Fibonacci e as pinturas de Da Vinci, podem ter sido criadas posteriormente à construção dessas obras, pelos estudiosos e autores que se predispuseram a encontrar número, medida e peso em tudo que viam; porém, podem ter sido criadas, utilizando a proporção áurea. $\mathrm{Na}$ verdade, não há registros sobre isso, mas conseguimos perceber nas relações que, realmente, existe um movimento para tentar descobrir se existem relações dessas obras com a razão áurea. Notamos que a visão dos pitagóricos de que tudo era número, medida e peso ainda sobrevive entre os estudiosos.

Observamos, ainda, que muitos dos conhecimentos quanto à razão áurea vêm da época dos pitagóricos e modificaram-se durante a História. Os sólidos platônicos, segundo Almeida (2001), não pertencem a Platão, já que se tem conhecimento de que três dos cinco são de pitagóricos, a saber, "o cubo, a pirâmide, e o dodecaedro, enquanto o octaedro e o icosaedro são devidos a Taeteto" (ALMEIDA, 2001, p.59). A relação deles com a natureza nos indica certo misticismo da sociedade pitagórica.

Observamos que a História serve como recurso pedagógico, pois trouxemos autores que afirmam considerações desconexas acerca de um mesmo fato, mas buscamos "as significações conceituais e político-filosóficas que estão na base do desenvolvimento orgânico desses fatos" (MIGUEL, 1993, p. 209). Além do mais, como professores, podemos pensar em entender a demonstração da razão áurea, feita por Euclides com os alunos, mostrando a eles termos e diferenças de linguagem ao longo da História e, posteriormente, desafiá-los a pensar na construção da razão áurea de outra maneira.

\section{Referências}

ALMEIDA, M. C. Platão Redimido-A teoria dos números figurados na ciência antiga \& moderna. Curitiba, 2001.

BÍBLIA, A. T. Sabedoria. In: BÍBLIA. Português. Bíblia Sagrada. Edição Pastoral: Antigo e Novo Testamentos. Tradução de Ivo Storniolo e Euclides Martins Balancin. São Paulo: Paulus, 2012. p. 847. 
BOYER, C. B. História da Matemática. Tradução de Elza F. Gomide, Edgar Blucher. São Paulo: Editora Universidade de São Paulo, 1974.

EUCLIDES. Os Elementos. Tradução e Introdução de Irineu Bicudo. São Paulo: Editora UNESP, 600p. 2009.

FRITZ, K.V.The Discovery of Incomensurability by Hippasus of Metapontum. In: Annals of Mathematics, v. 46, n. 2, abr. 1945.

HUNTLEY, H.E. A Divina Proporção. Tradução de Luís Carlos Ascêncio Nunes. Brasília. Editora Universidade de Brasília, 178p. 1985.

MARKWOSKY,G. Misconceptions about the Golden Ratio. The College Mathematics Journal, v. 23, n. 1, p. 2-19, jan. 1992.

MIGUEL, A. Três estudos sobre História e Educação Matemática.1993. 274p. Tese (Doutorado em Educação) - Faculdade de Educação do Departamento de Metodologia de Ensino, Universidade Estadual de Campinas. 1993.

PACIOLI, L. De Divina Proportione. Tradução e Comentários de Fábio Maia Bertato. Coleção CLE, 2010.

QUEIROZ, R. M. Razão Áurea: A beleza de uma razão surpreendente. Trabalho apresentado ao programa de Desenvolvimento Educacional. Universidade Estadual de Londrina. Londrina, 2007.

SANTOS, G. V. Explorando a Matemática do Número $\varphi$, o Número de Ouro. 66p. 2013. Dissertação (Mestrado em Matemática) - Programa de Pós-Graduação em Educação Matemática em Rede Nacional, Universidade Estadual Paulista Júlio de Mesquita Filho UNESP, Rio Claro, 2013. 


\section{HISTÓRIAS SOBRE NÚMEROS PERFEITOS E AMIGÁVEIS}

Jean Sebastian Toillier

\section{Introdução}

Os conceitos de números perfeitos e amigáveis foram desenvolvidos pelos pitagóricos e ainda hoje são tratados por alguns matemáticos, uma vez que sua teoria ainda é incompleta e está em busca de novos resultados. Assim, para compreender aspectos de sua importância para o desenvolvimento do pensamento matemático, principalmente no que diz respeito à teoria dos números, apresentaremos, neste capítulo, como se deu a evolução do conhecimento construído sobre esses temas.

Para que compreendamos o início do pensar sobre os números perfeitos e amigáveis, de maneira breve, apontamos a noção de número que os pitagóricos desenvolveram e como esse tratamento passou a ser feito. $\mathrm{Na}$ sequência, apresentamos uma noção geral do que são os números perfeitos e amigáveis e, em seguida, observamos seu desenvolvimento matemático e místico. Expomos, ainda, outros estudos que foram possíveis com o desenvolvimento das noções de números perfeitos e amigáveis, quer sejam números sociáveis e números multiperfeitos. Por fim, trazemos algumas considerações sobre nosso estudo bibliográfico e, também, das marcas do pitagorismo para o desenvolvimento matemático, principalmente em relação à teoria dos números.

\section{A noção de número para os pitagóricos}

Os números são objeto de estudo da humanidade. Sempre se buscou entender como eles surgiram, se foram associados com a escrita ou não, suas formas de representação, suas propriedades e as operações possíveis de 
serem realizadas. As inquietações sobre os números marcaram a filosofia na Grécia Antiga durante alguns séculos, e seus estudos deixaram marcas. Assim, um dos grupos que se preocupou no estudo do significado dos números foram os pitagóricos.

Os pitagóricos tiveram origem por volta do século $\mathrm{V}$ a.C., na Grécia Antiga, e esse grupo está vinculado à figura de Pitágoras de Samos, um filósofo e matemático que organizou essa sociedade. Dentre as várias discussões realizadas por eles destaca-se o conceito de número.

A noção de número que é empregada comumente remete apenas às quantidades de uma maneira abstrata, porém o sentido dado pelos pitagóricos era mais amplo (SANTOS, 2000). "A palavra número vem do termo nomos, que significa regra, lei, ordem (SANTOS, 2000, p. 111). O sentido dado pelos pitagóricos vinha da palavra arithmós, aplicado como número em um sentido genérico: "[...] vem do termo rythmós, do radical rhe, de onde rhêo, do verbo rhein, que significa fluir" (SANTOS, 2000, p. 110). Assim, da relação dessas palavras, conclui-se que "o fluxo da criação implica o número" (SANTOS, 2000, p. 110).

O conceito de número passaria a ser algo que leva em conta, além dos aspectos quantitativos abstratos, o sentido de essência verdadeira e eterna, recaindo no sentido de criação de todas as coisas, de todo o universo do qual fazemos parte (NICÔMACO, 1926). Para os pitagóricos, o número apresentava-se carregado de aspectos existenciais, ou seja, de aspectos da criação do mundo. Com isso, apontavam que tudo se originava do número, começando pela unidade:

O princípio de todas as coisas é a unidade: e a dualidade procede disso que é indiferente e depende, por princípio, da unidade que o causa. Assim, a numeração vem da unidade e da dualidade indiferente. Dos números vêm os pontos: destes, vêm as linhas: das linhas, as figuras planas: das figuras planas, as sólidas; e destas, os corpos sólidos, cujos quatro elementos consistem em fogo, água, terra e ar, que transcendem e giram através de todas as coisas, e delas o mundo é engendrado, animado, intelectual, esférico, que se abraça no meio da esfera também esférica, e habita ao seu redor (LAERCIO, 1972, p. 194, tradução nossa). 
Assim, para os pitagóricos, a explicação da ordem e da harmonia do mundo poderia ser feita com base nos números, uma vez que eles são a natureza de tudo o que pode ser percebido (ROQUE, 2012).

Já o conceito quantitativo abstrato de número estava relacionado com seus aspectos físicos e geométricos, uma vez que sua representação poderia ser feita por pedras. Além disso, a organização dos primeiros números ajudava a compor entes mais amplos:

Para ilustrar o modo como os números se compunham, os pitagóricos faziam uso de representações gráficas, procedendo da seguinte maneira: o um é o ponto (.); o dois a linha (._.); o três a superfície (./) e o quatro o volume (:). Dessa forma, os pitagóricos conseguiam demonstrar a composição dos primeiros números que para eles originavam todo o universo e alma das coisas (DUARTE; GONÇALVES; NÓBREGA, 2017, p. 103).

A soma desses primeiros números resulta em 10 , fazendo que ele carregue uma simbologia especial, como o número da criação. Assim, a junção dos 10 pontos formaria uma figura espacial, o tetraedro regular, tetractys, que seria a fonte de tudo, o modelo de todas as coisas (SANTOS, 2000).

Dessa forma, os números dentro da caracterização pitagórica carregavam esses vastos sentidos e suas propriedades passaram a ser estudadas mais profundamente.

\section{Números perfeitos e números amigáveis, primeiras considerações}

Os pitagóricos interessaram-se por propriedades aritméticas dos números e buscaram encontrar as características comuns entre eles ou entre as propriedades que cada número carregasse. Algumas dessas características estavam relacionadas com as ideias dos divisores de um número e, assim, surgiram alguns conceitos, como, por exemplo, os números perfeitos e amigáveis. Podemos afirmar que esse seria um princípio da teoria dos números.

Conforme Spencer (1995), por volta de meados do século VI a.C., Pitágoras (ou os pitagóricos) definiram as noções de números perfeitos e amigáveis. Em relação aos números amigáveis, uma lenda muito comum 
sobre o tema é descrita por Karlson (1961), a qual diz que, quando perguntado sobre o que seriam amigos, Pitágoras respondeu que "alguém que é um outro eu, como 220 e 284". Como assim? Vamos explicar em linhas gerais o que são números perfeitos e amigáveis, para que, depois, possamos discutir profundamente a questão. Porém, antes disso, é necessária uma pequena caracterização acerca de divisores próprios de um número.

Divisores próprios de um número positivo n são todos os divisores inteiros positivos de $\mathrm{n}$ exceto o próprio n. Por exemplo, os divisores próprios de 8 são 1, 2 e 4. Essa noção é importante para que possamos entender o que são números perfeitos e amigáveis.

Os números perfeitos são caracterizados por serem aqueles cuja soma de seus divisores próprios resultam no próprio número. Por exemplo, temos o 6. Veja que seus divisores próprios são 1,2 e 3 . Conforme a definição exposta acima, temos a soma $1+2+3=6$, logo, 6 é um número perfeito.

Se escolhermos ao acaso alguns números, não será fácil encontrar outros que carreguem essa característica. Existe apenas outro número perfeito menor que 100, o 28, que tem como divisores próprios o 1, 2, 4, 7 e 14 , cuja soma resulta em 28 . Os números que não são perfeitos, que são a grande maioria, recebem outras duas possíveis classificações: abundantes ou deficientes.

Um número é dito abundante quando a soma de seus divisores próprios excede o próprio número, como, por exemplo, o 18, cujos divisores próprios são 1, 2, 3, 6 e 9, que somados resultam em 21. Já um número deficiente é aquele cuja soma de seus divisores próprios é menor que o próprio número. Por exemplo, o 15, que tem como seus divisores próprios 1, 3 e 5, que somados resultam em 9 .

Já o outro tipo de número que chamou atenção dos pitagóricos foram os amigáveis ou “amigos”. Dois números são ditos amigáveis quando a soma dos divisores próprios de um deles resulta no outro. Como exemplo desses pares de números, temos o 220 e o 284, aquele citado por Pitágoras. Veja que os divisores próprios de 220 são 1, 2, 4, 5, 10, 11, 20, 22, 44, 55 e 110, que, quando somados, resultam em 284. Já os divisores próprios de 284 são 1, 2, 4, 71 e 142, que, quando somados, resultam em 220. 
$\mathrm{Na}$ sequência, trataremos acerca de como se deu o desenvolvimento de várias questões relacionadas aos números perfeitos e amigáveis, não apenas resultados matemáticos e novas teorias descobertas, mas como, ao longo dos anos, os números perfeitos tiveram representatividade em relação à religião.

\section{Outros estudos matemáticos e místicos sobre os números perfeitos e amigáveis}

Tanto os números perfeitos como os amigáveis foram objeto de estudos não somente dos pitagóricos, mas de vários outros matemáticos, o que levou à descoberta de mais números que satisfazem essas relações, uma vez que os pitagóricos conheciam pouco sobre eles.

O primeiro matemático conhecido por aprofundar os estudos sobre os números perfeitos foi Euclides (século III a.C.). Apesar de comumente as pessoas desavisadas acreditarem que as obras de Euclides continham apenas geometria, o famoso autor utilizou entes geométricos para dissertar sobre assuntos relativos à teoria dos números, por exemplo, questões de números pares, ímpares, primos e operações matemáticas.

$\mathrm{Na}$ proposição 36 do Livro IX, Euclides apresentou a existência de números perfeitos e provou a maneira de obtê-los por meio de representações geométricas. A proposição diz o seguinte: "Caso números, quantos quer que sejam, a partir da unidade, sejam expostos, continuadamente, na proporção duplicada, até que o que foi composto todo junto se torne primo, e o todo junto, tendo sido multiplicado pelo último, faça algum, o produzido será perfeito" (EUCLIDES, 2009, p. 349).

Dessa forma, tomemos $p=1+2+2^{2}+\ldots+2^{n}$ um número primo. Assim, pelo resultado de Euclides, temos que se $x=2^{n} p$, ele será um número perfeito. Especula-se que nessa época eram conhecidos apenas os quatro primeiros números perfeitos: 6, 28, 496 e 8128 (O'CONNOR; ROBERTSON, 2003). Reparem que para esses quatro números conhecidos o resultado era válido:

- Para $n=1$, temos $2^{1}(1+2)=6$

○ Divisores próprios de 6: 1, 2 e 3 
○ $1+2+3=6$

- Para $n=2$, temos $2^{2}\left(1+2+2^{2}\right)=28$

○ Divisores próprios de 28: 1, 2, 4, 7 e 14

○ $1+2+4+7+14=28$

- $\operatorname{Para} n=4$, temos $2^{4}\left(1+2+2^{2}+2^{3}+2^{4}\right)=496$

- Divisores próprios de 496: 1, 2, 4, 8, 16, 31, 62, 124, 248

○ $1+2+4+8+16+31+62+124+248=496$

- Para $n=6$, temos $2^{6}\left(1+2+2^{2}+2^{3}+2^{4}+2^{5}+2^{6}\right)=8128$

○ Divisores próprios de 8128 :

$1,2,4,8,16,32,64,127,254,508,1016,2032$ е 4064

$1+2+4+8+16+32+64+127+254+508+1016+$ $+2032+4064=8128$

Para facilitar a compreensão das próximas passagens do texto, transformaremos a escrita de Euclides para uma mais usual. Considerando que $1+2+2^{2}+\ldots 2^{n-1}=2^{n}-1$, temos que se $n>1$ e $x=2^{n-1}\left(2^{n}-1\right)$, $x$ é um número perfeito. Veja que, com essa forma, os valores de $n$ expostos acima não se mantêm, mas lhes é adicionada uma unidade. Assim, temos que:

- $\operatorname{Para} n=2$, temos $2^{2-1}\left(2^{2}-1\right)=6$;

- $\operatorname{Para} n=3$, temos $2^{3-1}\left(2^{3}-1\right)=28$;

- $\operatorname{Para} n=5$, temos $2^{5-1}\left(2^{5}-1\right)=496$;

- Para $n=7$, temos $2^{7-1}\left(2^{7}-1\right)=8128$.

Esse resultado não é válido para qualquer valor de $n$. Repare que, para $n=4$, temos que $2^{4-1}\left(2^{4}-1\right)=120$

A soma dos divisores próprios de 120 excede o número e, portanto, ele não é um número perfeito. Em seus estudos, Euclides não definiu para quais valores de $n$ seu resultado era válido.

Os resultados acerca dos números perfeitos voltaram a ser discutidos anos mais tarde por Nicômaco de Gerasa (60 d. C.-120 d. C.), em sua obra 
Introductio Arithmetica, na qual ele classificou os números em três classes: perfeitos, abundantes e deficientes. Porém, suas classificações não estavam relacionadas apenas ao caráter matemático, mas, também, aos aspectos estético e moral dos números (O'CONNOR; ROBERTSON, 2003).

Conforme Nicômaco (1926), pensar em um número abundante é relacionar com o exagero, com o excesso, com os abusos. É imaginar a figura de um animal que tenha dez bocas, por exemplo. Já um número deficiente representa algo como a ausência, o defeito, as privações e a insuficiência. Pode ser comparado a um animal que, em vez de ter dois olhos, tivesse apenas um.

Enquanto os números abundantes e deficientes representavam situações ruins e feias, os números perfeitos tinham como característica o contrário. Sua relação estava com a igualdade, a beleza, a sintonia, algo que pudesse regular a deficiência e o excesso (NICÔMACO, 1926).

Nicômaco (1926) também dissertou sobre informações matemáticas acerca dos números perfeitos. Exemplificou os números abundantes, deficientes e perfeitos, e apresentou os quatro primeiros números perfeitos: 6 , 28, 496 e 8128. Além disso, Nicômaco afirmou cinco características acerca dos números perfeitos, que se tornaram objeto de estudos por vários anos e por muitos matemáticos (O'CONNOR; ROBERTSON, 2003):

- O n-ésimo número perfeito tem $n$ dígitos;

- Todos os números perfeitos são pares;

- Todos os números perfeitos terminam alternadamente em 6 e 8;

- O algoritmo de Euclides para geração de números perfeitos nos dá todos os números perfeitos, ou seja, todo número perfeito terá a forma $2^{k-1}\left(2^{k}-1\right)$, para $k>1$, quando $2^{k}-1$ for primo;

- Existem infinitos números perfeitos.

Os resultados (1) e (3) já foram provados que não são verdadeiros, como apresentaremos adiante. Já os itens (2), (4) e (5) ainda são questionados e vários resultados foram desenvolvidos para demonstrar tais teorias, tanto nos aspectos legítimos como ilegítimos dessas características levantadas por Nicômaco. 
As explicações feitas por Nicômaco em sua obra não foram questionadas por muito tempo, devido não apenas ao caráter matemático, mas, principalmente, pelo aspecto religioso que suas afirmações carregavam, já que a perfeição tratada por ele servia como justificativa para a criação do mundo, em seis dias, e a do ciclo lunar, ou seja, o número de dias que a Lua leva para circundar a Terra, que são 28 dias. Esses aspectos místicos em torno dos números perfeitos ficarão cada vez mais intensos ao longo dos próximos séculos.

Jâmblico (por volta de 283-330 d.C.) apresentou em seus escritos que o par 220 e 284 era amigável, sem outros exemplos desses números (PICKOVER, 2009), mas fez menção aos estudos realizados por Pitágoras e à descoberta desse par. Também escreveu sobre os números perfeitos e afirmou erroneamente que entre cada potência de 10 existiria um, e somente um, número perfeito. Ainda, ressaltou o número 6 e todo o aspecto místico ao redor dele desenvolvido pelas teorias pitagóricas e o relacionou com o casamento, com a saúde e com a beleza (DICKSON, 1919).

$\mathrm{O}$ aspecto religioso em relação a esses números continuou sendo afirmado com o passar dos anos. Santo Agostinho (354-430) falou da perfeição do número 6 ao relacioná-lo ao momento de criação do universo por Deus (DICKSON, 1919). Para ele, Deus criou o mundo em seis dias para exemplificar a perfeição de seu trabalho. Anos mais tarde, Alcuíno de Iorque (735-804), um monge da Nortúmbria, atual Grã-Bretanha, discorre, em suas correspondências, sobre a criação do mundo e o número 6. Porém, Noé, quando construiu sua arca, salvou 8 almas e delas toda a humanidade foi gerada, ou seja, um número deficiente, pois a soma dos divisores próprios de 8 é igual a $7(1+2+4)$. Assim, a humanidade passa a ter um caráter de imperfeição em relação ao momento da criação.

Todas essas relações religiosas ocorreram dos estudos do Antigo Testamento da Bíblia Sagrada e não envolveram apenas os católicos cristãos, mas também a comunidade judaica. Os judeus perceberam que na escrita do Antigo Testamento várias eram as menções feitas aos números e que essa seria uma forma de provar os atos de Deus. Philo de Alexandria (25 a.C. -50 d.C.) foi um dos primeiros a relacionar a criação do mundo com o 
número 6, algo que se manteve anos depois, como pudemos observar. Esses eram argumentos importantes para mostrar que Javé era o verdadeiro Deus (PICKOVER, 2009). Além disso, em uma passagem do livro de Gênesis (Capítulo 32, versículo 14), Jacó deu ao seu irmão Esaú 220 cabras, o que, para muitos teologistas, seria um sinal de prova de amizade, uma vez que 220 é um número amigável.

A importância dos números perfeitos ganhou status tão grande entre os judeus que, durante o século XII, o rabino Josef ben Jehuda Ankin (11601226) recomendou o estudo dos números perfeitos em seu livro Healing of the Souls (Cura das Almas) (PICKOVER, 2009; DICKSON, 1919).

Os católicos também apontaram aspectos de perfeição relacionados aos atos divinos. Por exemplo, no século XII, Alberto Magno (1200-1280) relacionou o fato de 28 ser um número perfeito ao ciclo lunar, que é de 28 dias, como também o corpo místico de Cristo na Eucaristia surgir em 28 fases (PICKOVER, 2009).

O número 28 tem importância não apenas para a cultura católica, mas, também, para o Islã. Existiam 28 profetas antes de Maomé, segundo o Alcorão; e, além disso, os muçulmanos conectam as 28 mansões lunares ${ }^{1}$ com as 28 letras do alfabeto nas quais o Alcorão é escrito, o que, segundo o matemático al-Burini (1048), seria uma relação entre o cosmos e a palavra de Deus (PICKOVER, 2009).

Outro aspecto que chama atenção em relação à cultura árabe são os números amigáveis e o misticismo ao redor deles. Por exemplo, Ibn Khaldoum (1332-1406) relatou que havia uma busca por talismãs com os números 220 e 284 para trazer a relação de amizade íntima ou de união entre duas pessoas (DICKSON, 1919). Ibn el-Hasan (965-1040) e Ben Kalonymos (1286-1328) utilizaram o conceito de números amigáveis na astrologia (DICKSON, 1919).

\footnotetext{
${ }^{1} \mathrm{O}$ zodíaco é dividido em 12 signos com base no curso da Terra em torno do Sol, ao longo de um ano. Já as mansões lunares caracterizam o curso da Lua através das estrelas fixas durante um período de 28 dias. Dessa forma, as mansões lunares seriam como um zodíaco lunar.
} 
Por muito tempo, não existiram estudos matemáticos registrados acerca das questões dos números perfeitos e amigáveis, mas, como exemplificado anteriormente, esses conceitos ressoaram na cultura árabe. Uma das prováveis causas de tal fato se deve ao contato que esse povo teve com as obras gregas e com as possíveis produções dos povos do Mediterrâneo ao longo dos séculos, já que essa região passou pelo domínio árabe. Os árabes foram responsáveis pela tradução de muitas obras e, com isso, passaram a ser objeto de estudo. Desse modo, tiveram contato com a obra Os Elementos, de Euclides, e os números perfeitos e amigáveis voltaram a ser estudados em seu caráter matemático.

Durante muito tempo, os resultados sobre os números perfeitos demonstrados por Euclides, usando elementos geométricos, foram assumidos como algo verdadeiro. No século IX, o árabe Thabit ibn Qurra (836-901) fez estudos desses números, descobrindo importantes propriedades sobre eles, principalmente com indicações de características para um número ser considerado deficiente ou abundante (DICKSON, 1919). Além de Thabit, ibn el-Hasan (965-1040), conhecido na forma latina de seu nome Alhazen, provou em sua obra Tratado de análise e sintese que os números descritos na forma $2^{k-1}\left(2^{k}-1\right)$, para $k>1$, quando $2^{k}-1$ for primo, são realmente números perfeitos (O'CONNOR; ROBERTSON, 2009).

Ibn Ibrahim ibn Fallus (1194-1239) foi outro matemático árabe que estudou a questão dos números perfeitos a partir da escrita de um tratado baseado na obra Introdução à Aritmética de Nicômaco, na qual aprofundou os conhecimentos matemáticos sobre esses números, apresentando uma tabela com 10 números que eram supostamente perfeitos, sendo que, desses, os sete primeiros estavam corretos (O'CONNOR; ROBERTSON, 2003).

Os estudos sobre os números perfeitos não foram os únicos feitos por Thabit ben Qurra, uma vez que se dedicou também aos números amigáveis e trouxe um resultado para obter pares de números amigáveis, algo que, até então, não havia sido descrito por ninguém. Vejamos a forma elaborada por Thabit para a descoberta de pares de números amigáveis. 
Sejam as equações

$$
\begin{aligned}
& a=3 \cdot 2^{n}-1 \\
& b=3 \cdot 2^{n-1}-1 \\
& c=9 \cdot 2^{2 n-1}-1
\end{aligned}
$$

Se $a, b$ e $c$ forem números primos e $b \neq 2$, o par de números formado por $p=2^{n} a b$ e $q=2^{n} c$ serão números amigáveis.

Thabit realizou em seu trabalho a demonstração desses resultados usando como inspiração a prova feita por Euclides em Os Elementos (HOGENDIJK, 1985), ou seja, utilizou elementos geométricos para representação. Além disso, a própria escrita do resultado remetia à forma de enunciação feita por Euclides.

Com esse resultado acerca dos números amigáveis é possível obter alguns pares. Por exemplo, o par 220 e 284 é encontrado para $n=2$. Além disso, credita-se a Thabit ibn Qurra a descoberta do par 17296 e 18416, obtido pela substituição de $n$ por 4, algo que durante muitos anos foi creditado à Pierre de Fermat (1607-1665), uma vez que Thabit não deixou registrado em nenhum lugar o conhecimento desse par, mas conseguiu deduzir uma fórmula para obtê-lo (HOGENDIJK, 1985).

Esse resultado proposto por Thabit consegue gerar vários pares de números amigáveis, mas não é o responsável por gerar todos. Por exemplo, o par 1184 e 1210, descoberto por Niccolò Paganini (1782-1840), no século XIX, foge à regra expressa por Thabit (DICKSON, 1919). Porém, seu resultado continua válido para alguns pares e foi generalizado anos mais tarde, por Leonardo Euler (1707-1783). O que chama a atenção para o caso de Thabit é a forma evoluída para a época em relação à aritmética utilizada por ele, bem como a escrita desse seu resultado, uma vez que, naquele período, a escrita algébrica não tinha o mesmo caráter que apresenta atualmente.

A evolução do estudo dos números amigáveis foi ocorrendo ao longo dos anos. Marin Mersenne (1588-1648), Fermat e René Descartes (15961650), durante trocas de correspondência, discutiram sobre maneiras de obter esses pares de números. 
Após Fermat apontar que Mersenne encontrou o segundo par de números amigáveis 17296 e 18416 (o mesmo que Thabit, porém, anos depois), Fermat apresentou em uma carta um método para obter pares de números amigáveis ${ }^{2}$. Descartes também enviou para Mersenne outra regra, que, segundo o próprio Descartes, tinha como conclusão os mesmos resultados enviados por Fermat. Porém, quem recebeu o crédito da criação da regra por muito tempo foi Descartes (DICKSON, 1919). Ambas as regras tratavam de potências de 2 e foram feitas sem conhecer o trabalho de Thabit.

O grande salto sobre a questão dos números amigáveis foi feito por Euler, anos mais tarde, pois aprimorou os resultados de Thabit e demonstrou os resultados do matemático árabe. Euler deixou a fórmula proposta por Thabit em outra escrita, relacionando apenas com as potências de 2,o que, de certo modo, ajudou na demonstração dos resultados. Vejamos:

Sejam $p=2^{m}\left(2^{n-m}+1\right)-1, \quad q=2^{n}\left(2^{n-m}+1\right)-1 e$ $r=2^{n+m}\left(2^{n-m}+1\right)^{2}-1$, para $1 \leq m<n$. Se $p$, $q$ e $r$ são primos, $\left\{2^{n} p q, 2^{n} r\right\}$ é um par de números amigáveis.

Veja que, para $m=1$ e $n=2$, o par obtido é 220 e 284 .

Esse resultado encontrado por Euler é assumido até os dias atuais. Assim como o de Thabit, ele também não gera todos os pares de números amigáveis, mas Euler demonstrou que todos os pares que seguem as condições expostas acima o são ${ }^{3}$. Porém, nem todos os pares de números amigáveis são obtidos por uma lei geral. Em Escott (1946),é possível encontrar várias pequenas regras de separação de métodos feitas por matemáticos com o passar dos anos para a descoberta desses números, pois existe uma quantidade elevada de pares desses números. Por exemplo, apenas Euler encontrou 59 pares. Abaixo trazemos uma lista dos números amigáveis menores que 1.000.000 (Quadro 1).

\footnotetext{
${ }^{2}$ Esse método é descrito em Dickson (1919, p. 40).

${ }^{3}$ Algumas demonstrações simples e mais elaboradas acerca dos números amigáveis podem ser encontradas em Yan (2004).
} 
Quadro 1 - Lista dos pares de números amigáveis (a, b) menores que 1.000 .000

\begin{tabular}{|r|r|c|c|c|c|}
\hline \multicolumn{1}{|c|}{$\mathbf{A}$} & $\mathbf{B}$ & $\mathbf{A}$ & $\mathbf{B}$ & $\mathbf{A}$ & $\mathbf{B}$ \\
\hline 220 & 284 & 122.265 & 139.815 & 503.056 & 514.736 \\
1.184 & 1.210 & 122.368 & 123.152 & 522.405 & 525.915 \\
2.620 & 2.924 & 141.664 & 153.176 & 600.392 & 669.688 \\
5.020 & 5.564 & 142.310 & 168.730 & 609.928 & 686.072 \\
6.232 & 6.368 & 171.856 & 176.336 & 624.184 & 691.256 \\
10.744 & 10.856 & 176.272 & 180.848 & 635.624 & 712.216 \\
12.285 & 14.595 & 185.368 & 203.432 & 643.336 & 652.664 \\
17.296 & 18.416 & 196.724 & 202.444 & 667.964 & 783.556 \\
63.020 & 76.084 & 280.540 & 365.084 & 726.104 & 796.696 \\
66.928 & 66.992 & 308.620 & 389.924 & 802.725 & 863.835 \\
67.095 & 71.145 & 319.550 & 430.402 & 879.712 & 901.424 \\
69.615 & 87.633 & 356.408 & 399.592 & 898.216 & 980.984 \\
79.750 & 88.730 & 437.456 & 455.344 & 947.835 & 1.125 .765 \\
100.485 & 124.155 & 469.028 & 486.178 & 998.104 & 1.043 .096 \\
\hline
\end{tabular}

Fonte: Disponível em: <http://www.vaxasoftware.com/doc_eduen/mat/numamigos_eng. pdf $>$. Acesso em: 18 de fev. 2018.

Além dos números amigáveis, Euler foi o responsável por vários avanços em relação aos números perfeitos. Contudo, diferentemente da questão dos números amigáveis que não apresentaram muitos estudos ao longo dos anos, os números perfeitos receberam uma maior ênfase por outros matemáticos.

Segundo O'Connor e Robertson (2009), no começo do Renascimento, apenas os resultados apontados por Nicômaco eram conhecidos na Europa, enquanto as publicações árabes sobre os números perfeitos eram deixadas de lado. Assim, a proposição elaborada por Euclides mantinha o foco principal e muitas afirmações foram construídas sobre elas, algumas corretas, outras não. Por exemplo, Luca Pacioli (1447-1517) afirmou que a fórmula elaborada por Euclides era correta para todo $k$ ímpar. Outra relação importante foi feita por Charles de Bouvelles (1470-1553), que afirmou que os números perfeitos são números triangulares ${ }^{4}$, quando, num primeiro momento, não se falava sobre isso (DICKSON, 1919).

\footnotetext{
${ }^{4}$ Um número é dito triangular quando ele é resultado da soma da sequência $1+2+3+\cdots n$. Por exemplo, 6 é um número perfeito, resultado de $1+2+3=\epsilon$, assim como 28 , resultado de $1+2+3+4+5+6+7=2 \varepsilon$.
} 
Em um manuscrito alocado na Biblioteca Nacional de Florença, na Itália, e produzido entre 1456 e 1461, existe o primeiro registro encontrado do quinto número perfeito, 33550336 (obtido da forma $2^{12}\left(2^{13}-1\right)$ ), porém a autoria dessa descoberta é desconhecida (DICKSON, 1919; PICUTTI, 1989).

A descoberta do quinto número perfeito parece logo contradizer a quinta afirmação feita por Nicômaco ("existem infinitos números perfeitos"), no entanto, ela demorou anos para ser demonstrada, o que só foi possível ser feito no trabalho Utriusque Arithmetices, de 1536, escrito por Huldarichus Regius (século XVI) (O'CONNOR; ROBERTSON, 2009). Nele, Regius provou que o quinto número perfeito era 33550336, ou seja, não tinha cinco algarismos, refutando a primeira propriedade de Nicômaco, que afirmava que o $n$-ésimo número perfeito teria $n$ algarismos. Além desse estudo, Regius mostrou um importante resultado sobre a proposição de Euclides sobre os números perfeitos e trouxe a afirmação de que nem todo número escrito da forma $2^{n}-1$ é um número primo, justificando com o número $2^{11}-1=2047=23 \cdot 89$.

O sexto número perfeito aparece pela primeira vez em um documento que atualmente está na Biblioteca Apostólica do Vaticano (PICUTTI, 1989), datado de 1460. A autoria desse manuscrito é desconhecida, mas é do mesmo autor do manuscrito em que está registrado o quinto número perfeito. Dessa forma, conclui-se que, na Itália, nos meados do século XV, já eram conhecidos o quinto e o sexto número perfeito (PICUTTI, 1989).

Com os estudos de Pietro Antonio Cataldi (1548-1626), em 1588 (PICKOVER, 1997), após uma grande lista de cálculos manuais, em que apontava os divisores de vários números e alguns números primos (O'CONNOR; ROBERTSON, 2009), são apresentados o sexto e o sétimo números perfeitos. Esses números são descritos na forma $2^{16}\left(2^{17}-1\right)=8589869056$ e $2^{18}\left(2^{19}-1\right)=137438691328$. Com isso, caía a terceira afirmação feita por Nicômaco de que os números perfeitos terminavam alternadamente em 6 e 8, já que o quinto e sexto número terminam em 6. Cataldi ainda elaborou uma lista com vários números que afirmava serem perfeitos e que, anos mais tarde, alguns deles foram refutados. 
Após esse período de avanços sobre os números perfeitos, começaram a ser feitos estudos em outro caráter, já que o desenvolvimento de uma matemática com maior rigor começou a existir. Com isso, figuras como Descartes, Mersenne e Fermat, que já destacamos como responsáveis por discutir sobre os números amigáveis, voltam à cena agora para tratar das noções de números primos e de números perfeitos com base na troca de várias correspondências entre eles.

Em uma das cartas escritas de Descartes para Mersenne, em 1638, houve a discussão sobre a existência de apenas números perfeitos pares, enquanto os ímpares, se existissem, deveriam ter a forma $p s^{2}$, onde $p$ deveria ser um número primo (DICKSON, 1919). Em 1657, Frénicle de Bessy (1605-1675) afirmou que a hipótese de Descartes estava correta e que o número $p$ deveria ser escrito da forma $4 n+1$.

Outra carta com discussões importantes foi escrita por Fermat para Mersenne. Nela, Fermat traz alguns resultados obtidos em outras cartas trocadas com Gilles Roberval (1602-1675):

Aqui estão três proposições que descobri, sobre as quais espero construir uma enorme estrutura. Os números abaixo estão em uma sequência de potências de dois subtraído um.

$\begin{array}{ccccccccccccc}1 & 2 & 3 & 4 & 5 & 6 & 7 & 8 & 9 & 10 & 11 & 12 & 13 \\ 1 & 3 & 7 & 15 & 31 & 63 & 127 & 255 & 511 & 1023 & 2047 & 4095 & 8191\end{array}$

Chame-os de radicais de números perfeitos, porque quando eles não são primos, eles os produzem. Coloque acima desses números na sua progressão natural 1, 2, 3, 4, 5, etc., chamados seus expoentes. Depois de fazê-lo, eu digo.

1. Quando o expoente de um número radical é composto, seu radical também é composto. O 6, o expoente de 63, é composto, então eu digo que 63 será composto.

2. Quando o expoente é um número primo, afirmo que seu radical menos um é divisível pelo dobro do expoente. O 7, o expoente de 127, é um primo, então eu digo que 126 é um múltiplo de 14. 
3. Quando o expoente é um número primo, afirmo que seu radical não pode ser dividido por nenhum outro número primo, exceto aqueles que são maiores por um que um múltiplo que duplica o expoente...

Aqui estão três belas proposições que eu encontrei e demonstrei sem dificuldade. Eu as chamarei de fundamentos da invenção de números perfeitos. Não duvido que Frenicle de Bessy tenha chegado antes, mas acabei de começar e, sem dúvida, essas proposições passarão como algo encantador nas mentes daqueles que não se tornaram suficientemente hipócritas nesses assuntos, e ficaria muito feliz se eu tivesse a opinião de M. Roberval (O'CONNOR; ROBERTSON, 2003, sem página, tradução nossa $)^{5}$.

Após aprofundar seus estudos, Fermat chegou ao que hoje é conhecido como Pequeno Teorema de Fermat, o qual demonstra que, para qualquer primo $p$ e um integral $a$ não divisível por $p$, temos que $a^{p-1}-1$ é divisível por $p$. Com isso, Fermat conseguiu provar alguns dos erros cometidos por Cataldi ao supor a existência de alguns números perfeitos (O'CONNOR; ROBERTSON, 2003).

Para se ter ideia da eficácia do método encontrado por Fermat, em uma carta, Frenicle de Bessy questionou Fermat se existia um número

5 ... here are three propositions I have discovered, upon which I hope to erect a great structure. The numbers less by one than the double progression, like

$\begin{array}{lllllllllllll}1 & 2 & 3 & 4 & 5 & 6 & 7 & 8 & 9 & 10 & 11 & 12 & 13\end{array}$

$\begin{array}{lllllllllllll}1 & 3 & 7 & 15 & 31 & 63 & 127 & 255 & 511 & 1023 & 2047 & 4095 & 8191\end{array}$ let them be called the radicals of perfect numbers, since whenever they are prime, they produce them. Put above these numbers in natural progression 1, 2, 3, 4, 5, etc., which are called their exponents. This done, I say

-When the exponent of a radical number is composite, its radical is also composite. Just as 6 , the exponent of 63 , is composite, I say that 63 will be composite.

-When the exponent is a prime number, I say that its radical less one is divisible by twice the exponent. Just as 7 , the exponent of 127 , is prime, I say that 126 is a multiple of 14 .

- When the exponent is a prime number, I say that its radical cannot be divisible by any other prime except those that are greater by one than a multiple of double the exponent...

Here are three beautiful propositions which I have found and proved without difficulty, I shall call them the foundations of the invention of perfect numbers. I don't doubt that Frenicle de Bessy got there earlier, but I have only begun and without doubt these propositions will pass as very lovely in the minds of those who have not become sufficiently hypocritical of these matters, and I would be very happy to have the opinion of M Roberval. 
perfeito entre $10^{20}$ e $10^{22}$. Ao assumir a hipótese de Euclides, de que um número perfeito deveria ter a forma $2^{n-1}\left(2^{n}-1\right)$, onde $n$ é primo, Fermat se pôs a analisar se $2^{37}-1$ é composto (O'CONNOR; ROBERTSON, 2003).

Com seus resultados em mãos, Fermat reduziu a sua prova em demonstrar três itens:

Se $n$ é composto, $2^{n}-1$ é composto;

Se $n$ é primo, então $2^{n}-2$ é múltiplo de $2 n$;

Se $n$ é primo e $p$ é um divisor primo de $2^{n}-1$, então $p-1$ é múltiplo de $n$ (O'CONNOR; ROBERTSON, 2003, sem página, tradução nossa $)^{6}$.

De posse desses resultados, Fermat comprovou que $2^{37}-1=223 \times 616318177$, ou seja, um número composto. Dessa forma, não existe um número perfeito no intervalo de $10^{20}$ e $10^{22}$.

Os resultados alcançados por Fermat fizeram que Mersenne desenvolvesse uma teoria de que todo número escrito na forma $2^{n}-1$ seria primo para $n=2,3,5,7,13,17,19,31,67,127,257$ e que para nenhum outro valor superior a 257 ele não poderia provar, uma vez que os cálculos levariam muito tempo (O'CONNOR; ROBERTSON, 2003).

Com base nos estudos de Mersenne, foi desenvolvida outra categoria de números primos, os chamados primos de Mersenne. Esses números são caracterizados por serem primos escritos da forma $2^{n}-1$, onde $n$ é um número primo. Porém, nem todos os números que são gerados pela fórmula feita por Mersenne são primos. Por exemplo, o número $2^{11}-1=2047=23 \cdot 89$ não é um número primo,logo, não é um primo de Mersenne. Entretanto, esse resultado foi muito importante para que, anos mais tarde, Leonard Euler pudesse relacionar os primos de Mersenne com o resultado desenvolvido por Euclides acerca dos números perfeitos.

(i) If $n$ is composite, then $2^{n}-1$ is composite.

(ii) If $n$ is prime, then $2^{n}-2$ is a multiple of $2 n$.

(iii) If $n$ is prime, $p$ a prime divisor of $2^{n}-1$, then $p-1$ is a multiple of $n$. 
Em 1732, Euler determinou o oitavo número perfeito, que pode ser escrito da forma $2^{30}\left(2^{31}-1\right)$, com $\left(2^{31}-1\right)$ um número primo de Mersenne. Os outros sete números perfeitos também eram compostos por números primos de Mersenne, cujos expoentes eram 2, 3, 5, 7, 13, 17 e 19 (PICKOVER, 2009).

Euler, em seus manuscritos, conseguiu realizar uma série de provas em relação aos números perfeitos: todo número perfeito par deveria ter a forma sugerida por Euclides, ou seja, $2^{n-1}\left(2^{n}-1\right)$. Assim, Euler conseguiu provar a quarta hipótese de Nicômaco, pelo menos para o caso dos números pares. Já a questão acerca de todo número perfeito ter final 6 ou 8 , foi comprovada para todos os pares, porém não alternadamente, como afirmou Nicômaco. Por fim, em relação aos números perfeitos ímpares, Euler analisou o resultado exposto por Descartes e validou sua tese. Além disso, avançou na questão e afirmou que número perfeito ímpar deveria ter a forma $(4 n+1)^{4 \mathrm{k}+1} \mathrm{~b}^{2}$, com $4 n+1$ primo

Com o desenvolvimento da teoria feita por Euler, por muitos anos não se chegou a novos resultados, uma vez que os cálculos eram extensos e trabalhosos e havia desconfiança se seria possível encontrar números maiores do que o oitavo número perfeito (O'CONNOR; ROBERTSON, 2003). Apenas 150 anos depois dos estudos de Euler é que o próximo número perfeito foi descoberto por Édouard Lucas (1842-1891), em 1876, que seria o número $2^{126}\left(2^{127}-1\right)$ e que comprovava a hipótese de Mersenne, de $2^{127}-1$ ser um número primo de Mersenne.

Em 1883, o número perfeito $2^{60}\left(2^{61}-1\right)$ foi comprovado ser perfeito tanto por Ivan Pervushin (1827-1900) quanto por Paul Seelhoff (1829-1896), que o fez de maneira independente do primeiro, três anos depois. Isso possibilitou que muitos matemáticos passassem a defender a ideia de que a lista das potências elaborada por Mersenne possuía algum erro de interpretação ou grafia, uma vez que continha o 67 e o $2^{67}-1$ não constitui um primo de Mersenne (O'CONNOR; ROBERTSON, 2003).

Os números perfeitos ímpares voltaram a ser objeto de estudo quando James Joseph Sylvester (1814-1897), em 1888, afirmou que esse tipo de número deveria ter pelo menos cinco divisores principais diferentes. 
Benjamin Peirce (1809-1880) já havia demonstrado esse resultado de maneira independente. Em 1913, Leonard Eugene Dickson (1874-1954) provou que os distintos fatores primos de um número perfeito ímpar são finitos (YE, 2011).

O último resultado relevante sobre os números perfeitos ímpares foi feito por Robbins, em 1972, ao afirmar que um número perfeito ímpar pode ser divisível por pelo menos sete divisores principais diferentes (YE, 2011). Porém, até hoje não existe nenhum número perfeito ímpar descoberto.

Em relação aos números perfeitos pares ao longo do século $\mathrm{XX}$, com o desenvolvimento da matemática computacional, foi possível a obtenção de vários novos valores e que comprovam os resultados de Euclides, Mersenne e Euler. Segue um quadro com todos os números perfeitos descobertos até o momento:

Quadro 2-Lista dos números perfeitos descobertos

\begin{tabular}{|l|l|l|r|l|}
\hline Rank & $\begin{array}{c}\text { Ano da } \\
\text { descoberta }\end{array}$ & \multicolumn{1}{|c|}{ Número perfeito } & $\begin{array}{c}\text { Número de } \\
\text { digitos }\end{array}$ & \multicolumn{1}{|c|}{ Quem descobriu } \\
\hline 1 & 500 a.C. & $21 \times(22-1)=6$ & 1 & Gregos antigos \\
\hline 2 & 500 a.C. & $22 \times(23-1)=228$ & 2 & Gregos antigos \\
\hline 3 & 275 a.C. & $24 \times(25-1)=496$ & 3 & Gregos antigos \\
\hline 4 & 275 a.C. & $26 \times(27-1)=8126$ & 4 & Gregos antigos \\
\hline 5 & 1456 & $212 \times(213-1)=33550336$ & 8 & Anônimo \\
\hline 6 & 1588 & $216 \times(217-1)=8589869056$ & 10 & Pietro Cataldi \\
\hline 7 & 1588 & $218 \times(219-1)=137438691328$ & 12 & Pietro Cataldi \\
\hline 8 & 1772 & $230 \times(231-1)=$ & 19 & Leonhard Euler \\
\hline 9 & 1883 & $260 \times(261-1)$ & 37 & Ivan Mikheevich Pervushin \\
\hline 10 & 1911 & $288 \times(289-1)$ & 54 & R. E. Powers \\
\hline 11 & 1914 & $2106 \times(2107-1)$ & 65 & R. E. Powers \\
\hline 12 & 1876 & $2126 \times(2127-1)$ & 77 & Édouard Lucas \\
\hline 13 & 1952 & $2520 \times(2521-1)$ & 314 & Raphael M. Robinson \\
\hline 14 & 1952 & $2606 \times(2607-1)$ & 366 & Raphael M. Robinson \\
\hline 15 & 1952 & $21.278 \times(21.279-1)$ & 770 & Raphael M. Robinson \\
\hline 16 & 1952 & $22.202 \times(22.203-1)$ & 1.327 & Raphael M. Robinson \\
\hline 17 & 1952 & $22.280 \times(22.281-1)$ & 1.373 & Raphael M. Robinson \\
\hline 18 & 1957 & $23.216 \times(23.217-1)$ & 1.937 & Hans Riesel \\
\hline 19 & 1961 & $24.252 \times(24.253-1)$ & 2.561 & Alexander Hurwitz \\
\hline 20 & 1961 & $24.422 \times(24.423-1)$ & 2.663 & Alexander Hurwitz \\
\hline
\end{tabular}




\begin{tabular}{|c|c|c|c|c|}
\hline Rank & $\begin{array}{c}\text { Ano da } \\
\text { descoberta }\end{array}$ & Número perfeito & $\begin{array}{l}\text { Número de } \\
\text { dígitos }\end{array}$ & Quem descobriu \\
\hline 21 & 1963 & $29.688 \times(29.689-1)$ & 5.834 & Donald B. Gillies \\
\hline 22 & 1963 & $29.940 \times(29.941-1)$ & 5.985 & Donald B. Gillies \\
\hline 23 & 1963 & $211.212 \times(211.213-1)$ & 6.751 & Donald B. Gillies \\
\hline 24 & 1971 & $219.936 \times(219.937-1)$ & 12.003 & Bryant Tuckerman \\
\hline 25 & 1978 & $221.700 \times(221.701-1)$ & 13.066 & $\begin{array}{l}\text { Landon Curt Noll \& Laura } \\
\text { Nickel }\end{array}$ \\
\hline 26 & 1979 & $223.208 \times(223.209-1)$ & 13.973 & Landon Curt Noll \\
\hline 27 & 1979 & $244.496 \times(244.497-1)$ & 26.790 & $\begin{array}{l}\text { Harry L. Nelson \& David } \\
\text { Slowinski }\end{array}$ \\
\hline 28 & 1982 & $286.242 \times(286.243-1)$ & 51.924 & David Slowinski \\
\hline 29 & 1988 & $2110.502 \times(2110.503-1)$ & 66.530 & $\begin{array}{l}\text { Walter Colquitt \& Luke } \\
\text { Welsh }\end{array}$ \\
\hline 30 & 1983 & $2132.048 \times(2132.049-1)$ & 79.502 & David Slowinski \\
\hline 31 & 1985 & $2216.090 \times(2216.091-1)$ & 130.100 & David Slowinski \\
\hline 32 & 1992 & $2756.838 \times(2756.839-1)$ & 455.663 & David Slowinski \& Paul Gage \\
\hline 33 & 1994 & $2859.432 \times(2859.433-1)$ & 517.430 & David Slowinski \& Paul Gage \\
\hline 34 & 1996 & $21.257 .786 \times(21.257 .787-1)$ & 757.263 & David Slowinski \& Paul Gage \\
\hline 35 & 1996 & $21.398 .268 \times(21.398 .269-1)$ & 841.842 & GIMPS / Joel Armengaud \\
\hline 36 & 1997 & $22.976 .220 \times(22.976 .221-1)$ & 1.791 .864 & GIMPS / Gordon Spence \\
\hline 37 & 1998 & $23.021 .376 \times(23.021 .377-1)$ & 1.819 .050 & GIMPS / Roland Clarkson \\
\hline 38 & 1999 & $26.972 .592 \times(26.972 .593-1)$ & 4.197 .919 & GIMPS / Nayan Hajratwala \\
\hline 39 & 2001 & $213.466 .916 \times(213.466 .917-1)$ & 8.107 .892 & GIMPS / Michael Cameron \\
\hline 40 & 2003 & $220.996 .010 \times(220.996 .011-1)$ & 12.640 .858 & GIMPS / Michael Shafer \\
\hline 41 & 2004 & $224.036 .582 \times(224.036 .583-1)$ & 14.471 .465 & GIMPS / Josh Findley \\
\hline 42 & 2005 & $225.964 .950 \times(225.964 .951-1)$ & 15.632 .458 & GIMPS / Martin Nowak \\
\hline 43 & 2005 & $230.402 .456 \times(230.402 .457-1)$ & 18.304 .103 & $\begin{array}{l}\text { GIMPS / Curtis Cooper \& } \\
\text { Steven Boone }\end{array}$ \\
\hline 44 & 2006 & $232.582 .656 \times(232.582 .657-1)$ & 19.616 .714 & $\begin{array}{l}\text { GIMPS / Curtis Cooper \& } \\
\text { Steven Boone }\end{array}$ \\
\hline 45 & 2008 & $237.156 .666 \times(237.156 .667-1)$ & 22.370 .543 & $\begin{array}{l}\text { GIMPS / Hans-Michael } \\
\text { Elvenich }\end{array}$ \\
\hline 46 & 2009 & $242.643 .800 \times(242.643 .801-1)$ & 25.674 .127 & GIMPS / Odd M. Strindmo \\
\hline 47 & 2008 & $243.112 .608 \times(243.112 .609-1)$ & 25.956 .377 & GIMPS / Edson Smith \\
\hline 48 & 2013 & $257.885 .160 \times(257.885 .161-1)$ & 34.850 .345 & GIMPS / Curtis Cooper \\
\hline 49 & 2016 & $274.207 .280 \times(274.207 .281-1)$ & 44.677 .235 & GIMPS / Curtis Cooper \\
\hline 50 & 2017 & $277,232,916 \times(277,232,917-1)$ & 46.498 .850 & GIMPS / Jonathan Pace \\
\hline
\end{tabular}

Fonte: http://clubes.obmep.org.br/blog/rank-dos-numeros-perfeitos/ e https://en.wikipedia. org/wiki/List_of_perfect_numbers. Lista atualizada nos sites em 18 de fevereiro de 2018. 


\section{Alguns estudos decorrentes: números multiperfeitos e sociáveis}

Os estudos sobre números perfeitos e amigáveis tornaram possível a criação de novas teorias sobre alguns tipos de números e, com isso, que fossem aprofundados alguns tópicos relativos à teoria dos números. Trataremos dois exemplos aqui: os números multiperfeitos e os números sociáveis.

Os números multiperfeitos são uma classe de números que partiu da classificação dos números perfeitos. Um número $n$ é dito multiperfeito quando a soma de seus divisores inteiros positivos (agora incluindo o próprio número) resulta em um número $k n$, onde $k$ é um número natural. Nesse caso, dizemos que a ordem de um número multiperfeito $n$ será $k$.

A partir da definição exposta acima, podemos relacionar que todo número perfeito é também multiperfeito de ordem 2. Por exemplo, tomemos o número 6. Os seus divisores são 1, 2, 3 e 6, que, quando somados, resultam em 12 . Como $2 \cdot 6=12$, dizemos que 6 é um número multiperfeito de ordem 2 .

Os estudos sobre os números multiperfeitos tiveram início nas correspondências trocadas entre Mersenne e Descartes, em 1631 (ORE, 1976). Um dos números que chamou atenção deles foi o 120 , que pode ser classificado como um número multiperfeito de ordem 3 , dado que a soma dos seus divisores resulta em 360 (os divisores de 120 são 1, 2, 3, 4, $5,6,8,10,12,15,20,24,30,40,60$ e 120 , que, quando somados, resultam em 360).

Assim como aconteceu com os números perfeitos e amigáveis, Fermat também participou das discussões sobre essas teorias. Da mesma forma, Frénicle também trocou correspondências com Mersenne. O objetivo das cartas era o de discutir métodos para a obtenção de números multiperfeitos e relacioná-los com as diferentes ordens possíveis.

O primeiro a propor um método foi Descartes, porém Frenicle e Mersenne não acreditaram na eficácia do método elaborado por ele (ZHOU, 2010). Em uma próxima correspondência, Descartes encaminhou 
números que encontrou, além de afirmar que seu método poderia gerar infinitos números multiperfeitos ${ }^{7}$.

A seguir, apresentamos um quadro com alguns números multiperfeitos, juntamente com a sua ordem (Quadro 3).

Quadro 3 - Exemplo de números multiperfeitos

\begin{tabular}{|l|l|}
\hline Ordem & Números multiperfeitos \\
\hline 2 & $6,28,496,8128, \ldots$ \\
\hline 3 & $120,672,523776,459818240,1476304896,51001180160$ \\
\hline 4 & $30240,32760,2178540,23569920, \ldots$ \\
\hline 5 & $14182439040,31998395520,518666803200, \ldots$ \\
\hline 6 & $154345556085770649600,9186050031556349952000, \ldots$ \\
\hline
\end{tabular}

Fonte: http://mathworld.wolfram.com/MultiperfectNumber.html (acessado em 18 de fevereiro de 2018)

Outro tipo de números que foram descobertos em virtude dos números perfeitos e amigáveis foram os sociáveis. Para entender melhor o tema, pensemos da seguinte forma: os números perfeitos teriam ordem 1 , uma vez que, ao encontrarmos todos os divisores próprios de um número, ao somarmos, eles retornam para o mesmo número, por exemplo, o 6 e o 28 . Já os números amigáveis teriam ordem 2 , uma vez que os divisores próprios de 220, quando somados, resultam em 284 e vice-versa. Com os números sociáveis, a ordem de relação seria maior do que 2, ou seja, existiria uma "corrente fechada", na qual os elos seriam os números e cada elo estaria relacionado com outros dois.

Para facilitar, vejamos um exemplo. Em 1918, Paul Poulet (18871946) descobriu a seguinte corrente de números $12496 \rightarrow 14288 \rightarrow 15472 \rightarrow$ $14536 \rightarrow 14264 \rightarrow 12496$ (PICKOVER, 2009). As setas representam que a soma dos divisores próprios de 12496 resultam em 14288, que a soma dos divisores próprios de 14288 resultam em 15472, e assim sucessivamente até a corrente voltar para 12496.

\footnotetext{
${ }^{7}$ Não apresentaremos os métodos encontrados por Descartes e outras descobertas, uma vez que se trata de formas trabalhosas e deveríamos aprofundar algumas explicações. Como sugestão, os trabalhos de Dickson (1919) e Zhou (2010) discutem essas questões.
} 
$\mathrm{Na}$ mesma época, Poulet encontrou uma corrente com 28 números (Figura 1):

Figura 1 - Corrente de 28 números sociáveis

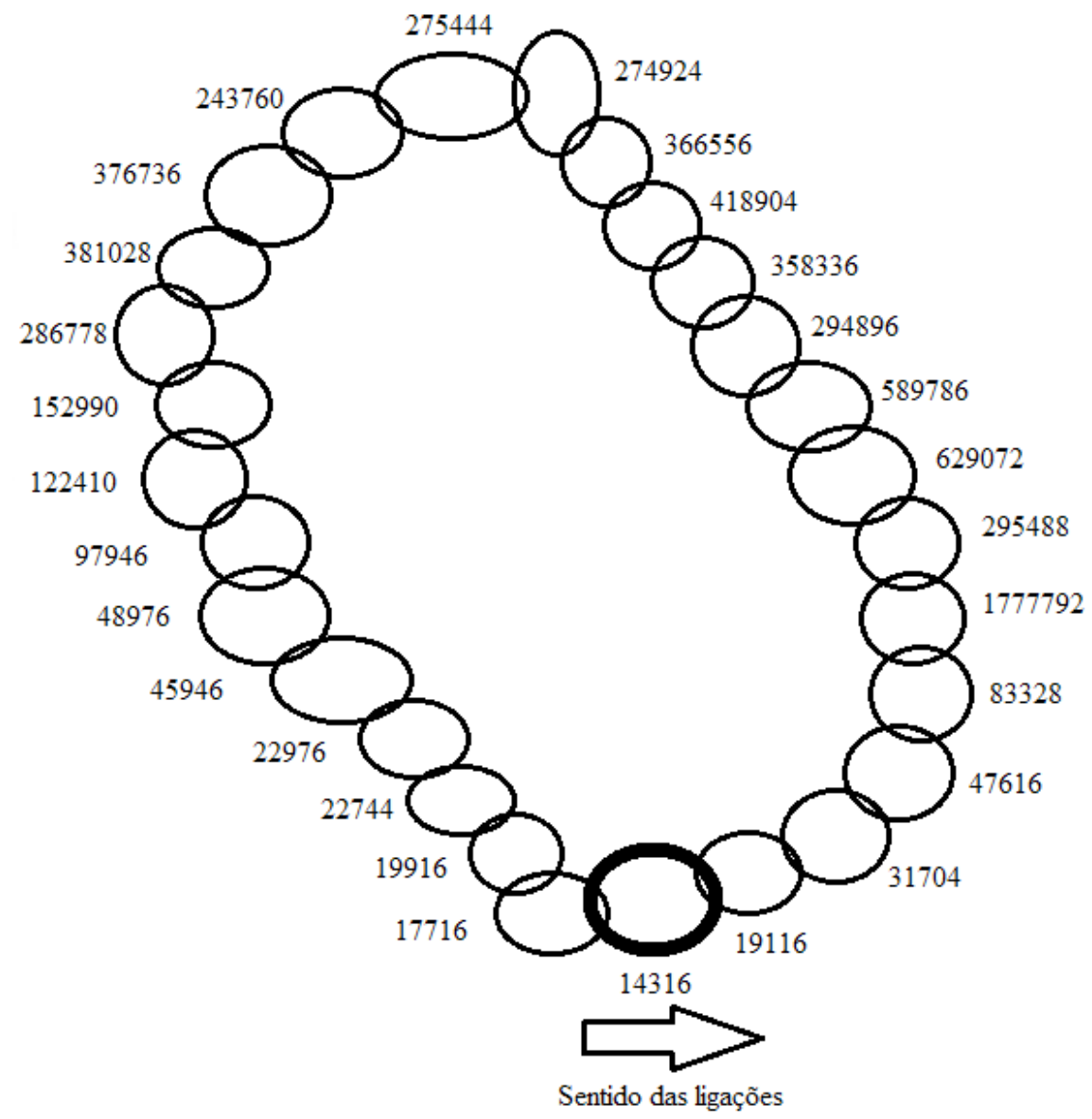

Fonte: Elaborado pelo autor a partir de Pickover (2009, sem página)

Em 1969, por meio de métodos computacionais aplicados a números menores que 60.000.000, Henry Cohen encontrou mais sete correntes de números sociáveis (SOCIABLE, 2013). 


\section{Considerações Finais}

Ao longo da história, os conceitos acerca dos números perfeitos e amigáveis ganharam destaque tanto no aspecto matemático quanto no aspecto místico. Inicialmente, os dois aspectos caminhavam juntos, mas apenas a partir do século XV é que o caráter matemático passou a receber mais destaque.

Os avanços sobre as conceituações fizeram que estudos antigos, como os de Euclides, fossem validados em sua grande parte, o que mostrou a importância de seu trabalho não só para a geometria, mas também para a teoria dos números.

Os estudos feitos por Descartes, Mersenne, Fermat e, principalmente, Euler, serviram como um grande avanço para a teoria dos números e possibilitou, até mesmo, criar outras teorias, como, por exemplo, os números multiperfeitos. Lembramos, ainda, que os três primeiros tratavam das ideias matemáticas a partir de cartas, método que foi muito eficaz para o desenvolvimento das ciências nesse período.

Apesar de um grande esforço dos matemáticos citados, pouco se soube dos avanços que foram feitos pelos árabes, anos antes. $\mathrm{O}$ acesso que eles tiveram às obras da Grécia Antiga possibilitou o desenvolvimento de teorias que foram muito avançadas para a época, ao pensarmos na própria forma de registro matemático e dos conceitos algébricos aplicados às soluções geométricas, uma das marcas de Euclides.

Desde o século XX, os avanços dos estudos sobre os números perfeitos, amigáveis, multiperfeitos e sociáveis são notáveis, uma vez que, com o advento da computação, houve uma facilidade muito grande para encontrar novas soluções.

Com isso tudo, podemos perceber o quão profunda foi essa marca deixada pelos pitagóricos e como as ideias acerca do conhecimento sobre os números permaneceram e ainda geram estudos específicos. Além disso, o misticismo ao redor dessa questão continuou e as suas marcas foram possíveis de perceber no cristianismo, no judaísmo e na cultura árabe. $\mathrm{O}$ conceito de que antes tudo era número mudou muito, mas a busca por explicações e pelo conhecimento continuou existente. 


\section{Referências}

DICKSON, L. E. History of the Theory of Numbers: Divisibility and primality. Washington, USA: Carnegie Institution of Washington, 1919.

DUARTE, L. D.; GONÇALVES, H. H.; NÓBREGA, N. P. Tudo é número: uma análise conceitual da ideia de número em Pitágoras. Revista Princípia, João Pessoa, n. 33, p. 99107, maio 2017.

ESCOTT, E. B. E. Amicable Numbers. Scripta Math, [S.1.], v. 12, p. 61-72, 1946.

EUCLIDES. Os Elementos. Tradução e introdução de Irineu Bicudo. São Paulo: UNESP, 2009.

HOGENDIJK, J. P. Thabit ibn Qurra and the Pair of Amicable Numbers 17296, 18416. Historia Mathematica, n. 12, p. 269-273, 1985.

KARLSON, P. A Magia dos Números. Porto Alegre: Editora Globo, 1961.

LAERCIO, D. Los diez libros de Diógenes Laercio. Tomo II. Tradução de Josef Ortiz Sanz. Madrid: Imprenta Real, 1972.

NICÔMACO. Introduction to Arithmetic. Translated into English by Martin L. D'Ooge. NY: Macmillam Company, 1926.

O'CONNOR, J. J. ROBERTSON, E. F. Perfect Numbers. 2003. Disponível em <http:// www-history.mcs.st-andrews.ac.uk/HistTopics/Perfect_numbers.html>. Acesso em: 17 fev. 2018.

ORE, O. Number theory and its history. New York, USA: Dover Publications, 1976.

PICKOVER, C. A. The loom of God: tapestries of mathematics and mysticism. New York, USA: Sterling, 2009.

PICUTTI, E. Pour 1'histoire des sept premiers nombres parfaits. Historia Mathematica, n. 16, p. 123-136, 1989.

ROQUE, T. História da Matemática: Uma visão crítica, desfazendo mitos e lendas. Rio de Janeiro: Zahar, 2012.

SANTOS, M. F. Pitágoras e o tema do número. São Paulo: IBRASA, 2000.

SOCIABLE numbers. 2013. Disponível em < https://mathlair.allfunandgames.ca/sociable. php>. Acesso em: 29 mar. 2018.

SPENCER, D. D. Key Dates in Number Theory History: From 10,529 B.C. to the present. Ormond Beach, Florida, USA: Camelot Publishing Company, 1995. 
YAN, S. Y. 2500 Years in the Search for Amicable Numbers. Advances in Mathematics, v. 33, n. 4, ago 2004.

YE, S. Y. Odd Perfect Numbers. 2011. Disponível em: <http://online.sfsu.edu/meredith/301/Papers/Term\%20Paper_Ye_Final.pdf>. Acesso em: 29 mar. 2018.

ZHOU, Q. Multiply Perfect Numbers of Low Abundance. Thesis: PhD in Philosophy, Waykato University, Hamilton, New Zealand. 145p, 2010. 


\section{OS NÚMEROS FIGURADOS: DAS ORIGENS ÀS SUAS ATUAIS CONFIGURAÇÕES}

Débora Vieira de Souza

"Tudo está arranjado segundo número."

Pitágoras

\section{Introdução}

Os números podem estar arranjados de diferentes formas, por meio de linguagens variadas. Uma delas pode ser feita pela representação visual, com o uso de figuras.

Neste capítulo, convidamos o leitor a conhecer aspectos elementares sobre números figurados. Nosso propósito é possibilitar uma visão geral sobre a configuração desses números, dos seus primórdios até suas explanações nos dias atuais. Ressaltamos que, embora os tipos de linguagens adotadas para representar esses números sejam distintos, a intenção é propiciar uma compreensão de como os estudos desse assunto se desenvolveram ao longo dos séculos e como, ainda hoje, conceitos atrelados a eles são abordados no ensino de Matemática.

Para explorar essas visões, destacamos interpretações pontuais sobre a ideia de número e sobre a influência dos pitagóricos nesse contexto. Para tanto, neste primeiro momento, propomos uma imersão em cenários passados, que retratam bases fundamentais atreladas à teoria dos números figurados.

\section{Um retorno às origens históricas}

Aspectos relacionados à ideia de número e à formação do universo e tudo o que nele se constitui, foram discutidos desde os primórdios da história da humanidade. Abordagens como essas eram, por vezes, ligadas 
a questões filosóficas, e preocupavam-se com reflexões acerca de princípios éticos, morais e políticos, em que a compreensão de números sempre se mostrou relevante.

A palavra número vem de numerus (em latim), que, por sua vez, vem de nomos, lei, norma (em grego). Corresponde-lhe, no grego, a palavra arithmós. Esta vem do termo rythmós, do radical rhe, de onde rheo, do verbo rhein, que significa fluir. Há um parentesco entre número e ritmo, portanto. Há uma analogia, em cujo logos ambos se identificam. O fluxo da criação implica o número (SANTOS, 2000, p. 110).

Nesse sentido, Oliveira (2010) afirma que arithmós é um conceito fundamental para o entendimento da filosofia do pitagorismo, o qual significa também: cálculo, soma, quantidade, ritmo. E, mais:

Dizia Pitágoras, o que é confirmado por todos os pitagóricos posteriores, que o arithmós era 'Khyma ex monadon synkeimenon', ou seja, a série móvel, que jorra (que flui) da mônada [...]. Arithmós é, assim, algo das coisas móveis, das coisas que conhecem mutações de quaisquer espécies [...]. Há arithmós (número), onde há geração e corrupção, onde há aumento e diminuição, onde há alteração, onde há movimento (transladação). Todas as coisas finitas, portanto, que constituem a série das coisas criadas, são números, têm números (SANTOS, 2000, p. 110, grifos do autor).

Essas afirmações retratam que o número fazia parte de tudo o que se constituía. $\mathrm{Na}$ visão dos pitagóricos, "o número não é apenas a medida do quantitativo pela unidade, mas é, também, a forma, como proporcionalidade intrínseca das coisas, e pode ser tomado, como realmente o é, sob diversas modalidades" (SANTOS, 2000, p. 111). Nesse sentido, a unidade é compreendida como um postulado pitagórico, que representa a oposição entre o limite e o ilimitado.

Santos (2000, p. 92) cita, em seus estudos, um fragmento no qual afirma que "Arquitas e Filolau dão, indiferentemente, à unidade o nome de mônada, e à mônada, o nome da unidade. A maior parte das vezes acres- 
centam à palavra mônada que não é a primeira, e que é posterior à mônada em si e à unidade”. $\mathrm{O}$ autor esclarece que há uma mônada primeira, a qual é transcendente a todas as coisas, que diz respeito à mônada em si, o ser único, que tem sua própria razão de ser; é o que é, e está ligada ao pensamento superior. A unidade serve como um momento de contrastes - tensão e aproximação - entre dois gêneros de realidade.

Nessas interpretações, todas as coisas que nos cercam têm o seu número, que é o arithmós, ou a sua ordem, a sua essência, e é essa conclusão que sustenta o argumento de que todo conceito é número. Ou seja, o número está muito além do quantitativo e a constituição e movimentação da natureza e do universo, por exemplo, compõem-se de diferentes ciclos.

Os números para os pitagóricos não são apenas quantidades, mas qualidades porque são símbolos, segundo Jâmblico na teologia dos números. O número um (1) é a Mônada, a unidade, a verdade imutável, o masculino-feminino, a semente, Zeus, a vida, a essência, o amigo e a ordem. $\mathrm{O}$ número dois (2) é a Díade, o indefinido, a diferença, a mutabilidade, o nascimento, o crescimento, o ilimitado, o movimento, Erato, Isis, Rhea, o impulso e o fluxo. O número três (3) é a Tríade, a proporção, a harmonia, o casamento, a paz, Hecate, a perfeição e a amizade. $\mathrm{O}$ número quatro (4) é a Tétrade, a natureza da mudança, Hércules e a chave da natureza (OLIVEIRA, 2010, p.70).

Para complementar a compreensão relativa a essas ideias, Oliveira (2010) faz referência a Aristóteles, destacando que há uma relação de perfeição na combinação desses números. Para isso, a formação do número dez é dada como exemplo:

Segundo Aristóteles, os pitagóricos dizem que: “(...) como o número dez parece ser perfeito e parece compreender em si toda a realidade dos números, eles afirmavam que os corpos que se movem no céu também deviam ser dez (...)”1. Ele está se referindo à tetractys, símbolo pitagórico

\footnotetext{
${ }^{1}$ A respeito do dez, Oliveira (2010) traz como referência os escritos de A5, 986a8, contidos em Metafísica, de Aristóteles.
} 
formado por dez pontos arranjados no formato de um triângulo, sendo a base formada por quatro pontos, a segunda camada por três, a terceira por dois e aponto por um, representando, portanto, a soma dos quatro primeiros números inteiros cujo resultado é dez $(1+2+3+4=10)$, número importantíssimo para Pitágoras (OLIVEIRA, 2010, p. 68).

A descrição anterior pode ser representada pelo modo a seguir (Figura 1):

Figura 1 - A Tetractys

Fonte: Elaborada pela autora

Ainda a respeito desse número, Oliveira (2010) observa que a década, como também era chamada, servia de base para o sistema numérico do Ocidente e que também representava o princípio de renovação cíclica, pois, após o dez, inicia-se a contagem a partir dele $(10+1=11,10+2=12$, e assim por diante). Nesse número, há representação da ordem dos cosmos ${ }^{2}$ e de outros aspectos: as faculdades humanas, as consonâncias musicais ${ }^{3}$, os princípios para a formação das figuras geométricas e outros conhecimentos esotéricos envolvendo os números e suas simbologias.

Lendas e misticismo também estavam atrelados à compreensão de certos números. Segundo Boyer (1974, p. 39), o "número sete, por exemplo, era objeto de especial respeito, presumivelmente por causa das sete estrelas errantes, ou planetas, das quais a semana se derivou”. Ainda conforme esse autor, várias civilizações antigas abordaram questões associadas à numerologia, ao místico. Investigações como essas estavam associadas à geometria, a qual também era chamada a ciência dos corpos celestes. Nesse sentido, essa

\footnotetext{
${ }^{2}$ A palavra cosmos é de origem grega e é entendida aqui como um todo ordenado, organizado. ${ }^{3}$ Relações complementares sobre música e pitagorismo podem ser encontradas no segundo capítulo deste livro: Música e Matemática Pitagóricas: suas influências no mundo musical.
} 
ciência "teria sua origem na aritmética e seu objeto seria as figuras formadas pelas conjunções zodiacais. Sua relação com a aritmética e com a música estaria embasada na astrologia, na teoria dos números figurados e na aritmologia" (BRITO, 1999, p. 103)4.

O termo aritmologia é relativo aos estudos sobre numerologia. De acordo com Brito (1999), há compreensão de que os pitagóricos se destacam como os primeiros a trabalhar no desenvolvimento de uma alegoria numérica associada a esse termo, mas vale ressaltar que não há uma origem única desse tipo de sistematização. Segundo a autora, Filon de Alexandria (século I) realizou a primeira forma sistemática de aritmologia da exegese bíblica judeu-alexandrina, a qual ficou conhecida em seu tratado chamado Sobre os números.

Outra expressão usada no estudo dos números, do ponto de vista místico, refere-se à gematria. Brito (1999) explica que essa palavra diz respeito a um sistema criptográfico no qual são atribuídos valores numéricos às letras, e complementa essas ideias, destacando que seus estudos originários foram na Grécia antiga. Nesse contexto, as letras e os números poderiam ter representações idênticas. Alfa $(\propto)$, por exemplo, representaria tanto uma letra do alfabeto quanto um número.

Os estudos sobre a aritmologia e a gematria colocam-se como reveladores de sabedoria, de acordo com Brito (1999). Segundo a historiadora, até a própria Bíblia traz alguma passagem relacionada a essa afirmação.

Conhecimentos como esses são relacionados à teoria dos números figurados e essa, por sua vez, teve grandes contribuições dos pitagóricos.

Como explanamos anteriormente, os números destacavam-se como relevantes em contextos variados. Desde os babilônios já havia considerações de que os movimentos nos céus estavam relacionados com medidas numéricas. Explicações racionais que eram ligadas à formação do universo também eram desejadas por filósofos como Tales de Mileto e Heráclito de Éfeso. Para o primeiro, por exemplo, o princípio que deu origem ao mundo era a água e, para o segundo, a base de tudo era o fogo. E a busca por enten-

\footnotetext{
${ }^{4} \mathrm{O}$ trabalho intitulado The tradition of Greek Arithmology, de Frank Egleston Robbins (1921), traz estudos mais aprofundados a respeito da história da aritmologia.
} 
dimentos como esses estava ligada à reprodução de figuras geométricas no universo (BRITO, 1999).

A esse respeito, a autora afirma que o fato de poder expressar intervalos musicais por meio de razões numéricas, e que as trajetórias dos astros que resultavam da composição de movimentos circulares e não de movimentos irregulares, como antes se pensava, foram fatos que levaram os membros da escola pitagórica a acreditarem que todas as explicações pertinentes ao universo poderiam ser dadas por meio dos números e das formas geométricas, assim como as relações existentes entre ambos.

Desse modo, apresentamos um cenário geral que contempla desde as origens históricas até as configurações atuais dos números figurados, o qual está atrelado à visão de que tudo é arranjado ou construído, segundo o número - o princípio formador de todas as coisas. Para tanto, inicialmente, abordaremos estudos sobre esses números na visão do pitagorismo e de um importante estudioso chamado Nicômaco de Gerasa (60 - 120 d. C.), o qual era neopitagórico.

\section{A contribuição dos pitagóricos na teoria dos números figurados}

A fundação da escola pitagórica está atrelada ao nome de Pitágoras, que Boyer (1974) afirma ter sido filósofo, místico, profeta, além de ser um dos grandes colaboradores no desenvolvimento do conhecimento matemático. Segundo embasamentos históricos, Pitágoras nasceu em Samos, uma ilha localizada em Dodecaneso. Boyer observa que houve dificuldade para caracterizar a figura de Pitágoras, pois a chamada escola pitagórica era uma sociedade secreta e os trabalhos ali desenvolvidos eram compartilhados entre todos, e as descobertas realizadas eram atribuídas à escola, e não a um membro específico.

Roque (2012) retrata duas visões acerca do homem Pitágoras: uma dada por Jâmblico, que viveu entre os séculos III e IV da Era Comum, e outra, dada por Proclus. Jâmblico publicou obras relacionadas a Pitágoras e às suas contribuições à matemática, e no Catálogo dos Geômetras, de Proclus, constam os maiores indícios de que houve um matemático chamado Pitágoras. No entanto, segundo Roque (2012), isso é questionável, pois em 
outros estudos, como os de Eudoxo (408 - 355 a. C.) e Aristóteles (384 - 322 a. C.), há menção apenas aos pitagóricos, não há nada particular relacionado a um homem chamado Pitágoras.

Nosso olhar volta-se para os números figurados, elementos de importante discussão no campo da matemática e da filosofia, desde os primórdios da civilização. Nesse sentido,

A matemática atribuída a Pitágoras é a aritmética de pontinhos [...], mas não se sabe ao certo se ela é uma criação de um matemático chamado Pitágoras, de integrantes de uma escola antiga chamada pitagórica (mas não de Pitágoras), ou dos neoplatônicos e neopitagóricos da Antiguidade, como Jâmblico e Nicômaco (ROQUE, 2012, p. 105).

A ideia de número e as concepções de que seria constituído de tudo o que há no universo desenvolveu o entendimento de que a origem dos números se dava pela aglomerações de unidades ${ }^{5}$, iniciando os primeiros estudos sobre a teoria dos números figurados.

Como pontuamos em seções anteriores, arithmós era algo fundamental na compreensão do universo. De acordo com Boyer (1974), por meio dos pitagóricos, entende-se que a aritmética pode ser considerada como uma disciplina intelectual, que ia além de um estudo técnico, envolvendo, também, o conhecimento filosófico. Foram esses estudiosos que fizeram da aritmética "uma base para a unificação de todos os aspectos do mundo que os rodeava" (BOYER, 1974, p. 39). Esse historiador, assim como Roque (2012), descreve que a aritmética da escola pitagórica é definida por meio da configuração de pontos, a qual também é chamada de unidade sem extensão.

$\mathrm{O}$ pitagorismo compreendia que questões relativas à natureza admitem uma explicação universal para as coisas, que pode simbolizar a totalidade do cosmos. Para os pitagóricos, tudo poderia ser entendido pelos números e eles afirmavam que o mundo era formado, antes de qualquer coisa, por um "arranjo bem-ordenado e tal ordem se baseia no fato de

\footnotetext{
${ }^{5}$ De acordo com Szabó (1978, p. 257), "numbers, however, are defined as multitudes composed of units", ou seja, são interpretados como aglomerações de mônadas.
} 
que as coisas são delimitadas e podem ser distinguidas umas das outras" (ROQUE, 2012, p. 104).

A partir dessas referências, é possível compreender o quanto a afirmação de que "tudo é número" era fortemente defendida pelos pitagóricos; afinal, tudo se amparava na organização natural do universo e de tudo o que nele se constitui.

Os princípios (arkbai) - no sentido de origens do número e de tudo e de todas as coisas, são o Mesmo e o Outro - ou a "qualidade de ser a mesma coisa ou de ser outra coisa" (SANTOS, 2000, p. 121) correspondem a uma definição associada à interpretação de números puros, que constituem a matéria da aritmologia.

Roque (2012) afirma que os pitagóricos não possuíam, de fato, uma noção de número puro e, ainda assim, são vistos como os primeiros a considerar o número do ponto de vista teórico e não apenas prático.

Segundo a autora, as teses pitagóricas não faziam nenhuma separação entre número e corporeidade, nem entre seres corpóreos e incorpóreos. Para eles, os objetos matemáticos, que conhecemos hoje como entes abstratos, não eram assim compreendidos, pois suas configurações estavam atreladas às noções concretas e espaciais.

Os números figurados da escola pitagórica referiam-se a elementos discretos, estavam ligados à organização de pedrinhas, e se constituíam por meio de uma multiplicidade de pontos que não eram matemáticos.

Sendo assim, a estruturação dos números partia das compreensões a respeito de números pares e ímpares. Os pitagóricos, nas palavras de Boyer (1974), tinham o número Um como o gerador de todos os outros números, e também o consideravam o número da razão. Isso porque, de acordo com fragmentos de textos de Filolau, citados por Santos (2000), o Um é entendido como unidade, monas, e representa o princípio de todas as coisas; ele é o Ser Supremo do pitagorismo:

O Um é o Ser Supremo, Deus. Este está acima dos contrários acima do limitado e do ilimitado. O limite aproxima as coisas ao Um mas não o atinge, e é pela ilimitação que se produz a série inferior. Deus é a causa 
das causas, a causa primeira de todas as coisas, e ultrapassa em dignidade a todas elas (SANTOS, 2000, p. 89).

Além dessa interpretação do número $\mathrm{Um}$, os membros da comunidade pitagórica também consideravam outros números: os ímpares e os pares. Para eles, os ímpares representavam números masculinos e os pares eram vistos como femininos.

O dois, por exemplo, era tido como o primeiro número par feminino, o número da opinião. Assim como os demais números pares, ele representava o limitado. Já o número três é o primeiro ímpar masculino verdadeiro, que se associa às relações harmônicas. Ele e os demais ímpares representavam o ilimitado.

Ampliando essas ideias, exemplificamos a formação do número cinco, o qual representa o número do casamento, dado pela união dos primeiros números verdadeiros masculino e feminino:

Os pitagóricos entendiam que o ímpar e o par existiam antes de qualquer coisa. Da união de ambos, ou seja, desse casamento, surgiu o Um, que não representa um número. 'O Um é ao mesmo tempo par e ímpar, ser bissexuado a partir do qual os outros números se desenvolveram. $\mathrm{O}$ par e o ímpar são elementos dos números e na conjugação limitado-ilimitado está a oposição cósmica primordial por trás do mundo, expresso em números'(ROQUE, 2012, p. 105).

Desse modo, a partir dessa configuração, todos os demais números teriam sido gerados a partir do Um. Ou seja, não havia uma configuração que, necessariamente, descrevia as mesmas relações internas. Existiam peculiaridades distintas para essas formações e, com isso, era possível pensar na teoria dos números figurados.

Um ponto gera as dimensões, dois pontos determinam uma reta de dimensão um, três pontos não alinhados determinam um triângulo com área de dimensão dois, e quatro pontos não coplanares determinam um tetraedro com volume de dimensão três; a soma dos números que representam todas as dimensões é, portanto, o adorado dez (BOYER, 1974, p. 39). 
Esse trecho retrata como os números eram atrelados às dimensões geométricas e, novamente, trazemos o dez, como o número da perfeição, uma representação sagrada, pois representava o número do universo, o qual incluía a soma de todas as possíveis dimensões geométricas.

Baron (1985, p. 16) também descreve, em sua obra, o quanto essas concepções geométricas estavam ligadas à interpretação da matéria e da formação do universo.

Eles chamaram um ponto de um, uma reta de dois, uma superfície de três, e um sólido de quatro. O somatório de pontos gerava retas, o de retas, superfícies e o de superfícies, sólidos; com os seus um, dois, três e quatro eles poderiam construir o universo!

As questões envolvendo geometria, disposição dos números e ideias associadas à verdade e perfeição, estão muito atreladas às concepções pitagóricas. $\mathrm{Na}$ sequência, apresentamos mais explanações relativas à teoria dos números figurados, agora, na perspectiva do neopitagórico Nicômaco de Gerasa.

\section{Nicômaco de Gerasa}

A compilação de estudos a respeito dos números figurados, como uma teoria, está associada ao nome de Nicômaco de Gerasa, em sua obra Introductio Arithmeticai (100 d. C.). Segundo indícios, esse livro é um dos poucos documentos históricos que contêm uma ampla abordagem a respeito dos números figurados, tanto é que seus princípios foram utilizados como um manual na Antiguidade, que também se estendeu à Idade Média. Aliás,

[...] tanto na obra dos primeiros pitagóricos e dos neopitagóricos, o estudo dos múltiplos, submúltiplos, proporções e números figurados também estava presente nos textos sobre aritmética da Idade Média [...]. Os números figurados estão presentes na obra de Nicômaco (livro II), fonte de Boécio. Porém, nela, eles são apresentados na parte destinada ao estudo da geometria (BRITO, 2007, p. 132). 
Nicômaco foi um dos membros do grupo dos neopitagóricos. Não se sabe muito sobre sua vida. Ele não era visto como um matemático propriamente dito. Baron (1985, p. 132) afirma que essa obra, Introdução à Aritmética, "nos forneceu a melhor e mais completa descrição dos números figurados".

Brito (2007) reforça que os membros da escola pitagórica se preocupavam em criar convenções que acomodassem o universo com essa teoria qualitativa dos números, o que permitiu que, tanto a aritmética quanto a aritmologia, estivessem embutidas nas teorias pitagóricas.

Considerar esses aspectos revela a importância da obra de Nicômaco (1926), o qual, a partir do Capítulo VI, do livro II, demonstra o interesse de seus escritos. O filósofo afirma que, primeiramente, se deveria pesquisar e observar conhecimentos pertinentes aos números lineares, planos e sólidos, e cúbicos e esféricos, equilátero e escaleno, dentre outros, pensando também em tijolos, vigas etc., e tais exemplos estão todos associados a uma Introdução Geométrica.

Segundo Duarte, Gonçalves e Nóbrega (2017, p. 2), "a escola pitagórica no início utilizava o $\propto$ para realizar a representação gráfica dos números, criando a ideia de que a unidade $\propto=1$, em seguida, se passou a fazer o uso de pontos (.) para demonstrar essa teoria”.

Segundo Duarte, Gonçalves e Nóbrega (2017), a escola pitagórica utilizava o $\propto$, inicialmente, para realizar a representação gráfica dos números, criando a ideia de que a unidade era igual a $1(\propto=1)$. Em seguida, ela passou a fazer o uso de pontos (.) para demonstrar essa teoria.

$\mathrm{E}$, notadamente, é assim que o Capítulo VI da Introdução à Aritmética se inicia. Nicômaco (1926) descreve que certas convenções devem ser realizadas, não por natureza, mas segundo critérios dados pelo homem. Conforme o autor, a escrita de uma unidade seria representada por um alfa $(\alpha)$, o qual é o número um. Duas unidades, lado a lado, que já representam uma série de alfas, indica o sinal para 2. Ao dispor três alfas em uma linha, a representação corresponde ao três; já quatro em uma linha representam o quatro, e assim sucessivamente. $\mathrm{O}$ autor descreve que 
esse tipo de notação envolve a disposição dos números planos e sólidos e pode ser vista como:
O número 1: $\quad \alpha$
O número 2: $\quad \alpha \quad \alpha$
O número 3: $\quad \alpha \quad \alpha \quad \alpha$
O número 4: $\quad \alpha \quad \alpha \quad \alpha \quad \alpha$
O número 5: $\quad \alpha \quad \alpha \quad \alpha \quad \alpha \quad \alpha \quad \alpha$

Segundo Nicômaco (1926):

\begin{abstract}
A unidade, então, ocupando o lugar e o caráter de um ponto, será o início de intervalos e de números, mas não ele próprio um intervalo ou um número, assim como o ponto é o início de uma linha, ou um intervalo, mas não é linha ou intervalo. Na verdade, quando um ponto é adicionado a um ponto, ele não aumenta, pois quando uma coisa não dimensional é adicionada a outra coisa não dimensional, não terá dimensão; como se alguém examinasse a soma de nada adicionado a nada, o que faz nada [...]. A unidade, portanto, é adimensional e elementar, e a dimensão primeiro é encontrada e vista em 2 , depois em 3 , depois em 4 e em sucessão nos seguintes números; a dimensão é que é concebida entre dois limites (NICÔMACO, 1926, p. 237, tradução nossa) ${ }^{6}$.
\end{abstract}

Por isso, para Nicômaco, a unidade não é dimensional. Assim, chama-se linha, à primeira dimensão, a qual é estendida em uma direção. No caso de abordar duas dimensões, dá-se o nome de superfície, porque pode ser estendida em duas direções. Quando essa extensão ocorre em três dire-

\footnotetext{
${ }^{6}$ Originalmente: "Unity, then, occupying the place and character of a point, will be the beginning of intervals and of numbers, but not itself an interval or a number, just as the point is the beginning of a line, or an interval, but is not itself line or interval. Indeed, when a point is added to a point, it makes no increase, for when an non-dimensional thing is added to another non-dimensional thing, it will not thereby have dimension; just as if one should examine the sum of nothing added to nothing, which makes nothing [...]. Unity, therefore, is non--dimensional and elementary, and dimension first is found and seen in 2, then in 3, then in 4 and in sucession in the following numbers; for dimension is that is conceived of as between two limits".
} 
ções, ou seja, em três dimensões, ela é nomeada como sólido e apresenta profundidade, largura e comprimento.

Para melhor compreensão, ampliaremos essas temáticas por meio de enfoques abordados no livro II, de Nicômaco (1926), a respeito da formação dos números figurados planos, a saber: os números triangulares, quadrados, pentagonais, hexagonais, e seus sucessores. Para tanto, utilizaremos diferentes representações, dentre elas, a representação visual.

Os números triangulares

Nicômaco de Gerasa descreve que um número triangular, quando analisado em unidades, apresenta-se em formato triangular, em que suas peças se dispõem por meio de formas regulares, sendo ao mesmo tempo triangulares e equiláteras. Essas peças são dispostas em um plano do seguinte modo: 3, 6, 10, 15, 21, 28 e, assim, sucessivamente.

Segundo o autor, um número triangular é obtido a partir da série natural do número 3 , a qual é composta em uma linha pela adição contínua de números sucessivos, um a um. Assim, desde o início dessa disposição, ocorrem sucessivas combinações e adições de outro termo à soma e, então, os números triangulares na ordem regular vão sendo completados. Da série natural $1,2,3,4,5,6,7,8, \ldots, 15$, por exemplo, toma-se o primeiro termo e obtém-se o número triangular que é potencialmente o primeiro: $2+1=3$.

Dessa forma, a representação gráfica é dada por duas unidades lado a lado, que é definida abaixo de uma unidade e o número três, que é interpretado como um triângulo. Logo, quando, nessa formação, adicionamos o 3, obtemos, então, o 6, que é considerado o segundo número triangular. Novamente, o número que se segue naturalmente é 4, o qual, ao ser adicionado e colocado abaixo do anterior, gera o número triangular 10. Sucessivamente, são adicionadas 5 unidades, depois 6, e todos os números em ordem são adicionados de forma regular, sendo que cada triângulo formado consistirá dos números correspondentes à sequência natural para produzi-los. Vejamos a representação gráfica desses procedimentos (Quadro 1): 
Quadro 1 - Os números triangulares

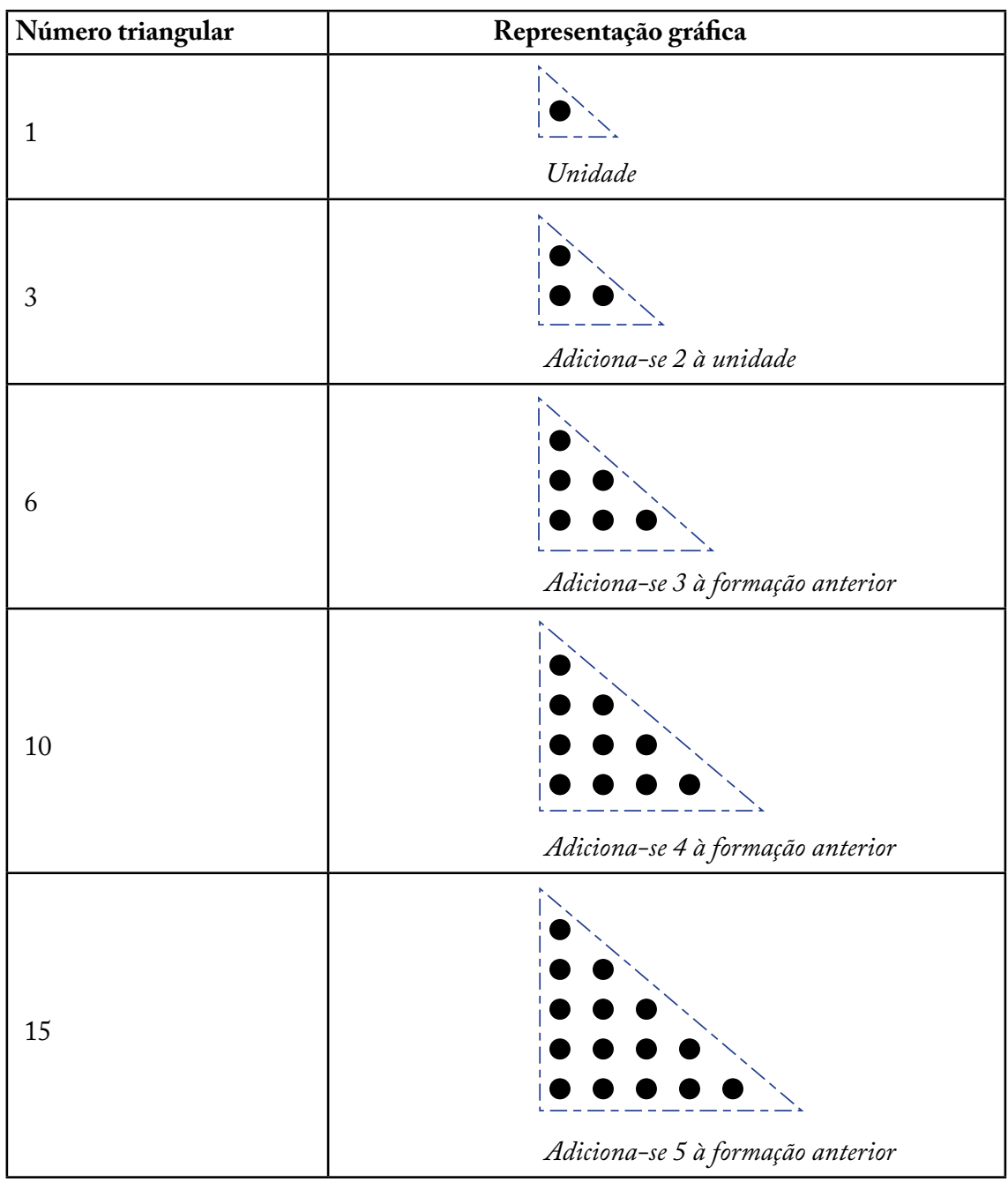

Fonte: Elaborado pela autora

\section{Os números quadrados}

Seguindo as considerações da obra de Nicômaco, temos as representações dos próximos números figurados, os quais são chamados de números quadrados. Nesse caso, as figuras em destaque são os quadrados e todas as suas representações numéricas são números equiláteros. Como exemplo, 
temos: 4, 9, 16, 25, 36, 49, 64, 81, 100 e assim por diante. Tais números, assim como os números triangulares, respeitam certa regularidade em sua formação, e seus lados progridem de acordo com a série natural.

De acordo com a regularidade, o lado do quadrado dito como potencialmente primeiro, 1 , é o 1 ; o lado de 4 é o 2 , é na verdade o primeiro; o lado correspondente ao 9 é o 3 , interpretado como o segundo; o de 16, é 4, o qual é tido como o terceiro; o quinto número figurado é o 36 , representado pelo lado 6 e, assim, sucessivamente.

Outra forma de se obter esse número figurado pode ocorrer se a série natural se estender a uma linha aumentando por 1, ou seja, a formação não mais se dará através de sucessivas somas adicionadas aos números em ordem, mas em relação a todos aqueles de modo alternado, respeitando a organização dos números ímpares. Assim, 1 é potencialmente o primeiro quadrado; a soma de $1 \mathrm{com} 3$, representa o segundo que, na verdade, representa o primeiro número quadrado; a terceira formação representa, na verdade, o segundo número quadrado é e dado pela soma de $1 \mathrm{com} 3 \mathrm{com}$ 5; a quarta formação, dada pela soma de 1,3, 5 e 7, resulta na verdade no terceiro número quadrado e, assim, sucessivamente. Observe essas representações no quadro 2 a seguir:

Quadro 2- Os números quadrados

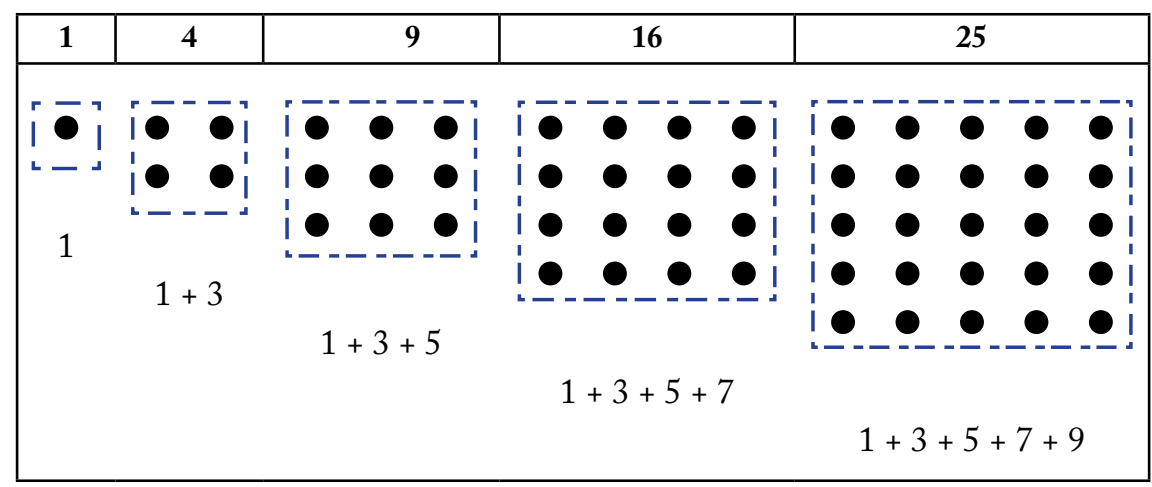

Fonte: Elaborado pela autora

$\mathrm{Na}$ disposição numérica observada (Quadro 2), podemos perceber outras relações matemáticas envolvidas. Por exemplo, a configuração 
formada foi construída pela somatória dos $n$ primeiros números ímpares. Veja:

$$
\begin{aligned}
& 1=1 \\
& 4=1+3 \\
& 9=1+3+5 \\
& 16=1+3+5+7 \\
& 25=1+3+5+7+9 \\
& 36=1+3+5+7+9+11 \\
& 49=1+3+5+7+9+11+13
\end{aligned}
$$

Esses números recebem o nome de quadrados perfeitos, ou seja:

$$
\begin{array}{llll}
1=1^{2} & 4=2^{2} & 9=3^{2} & 16=4^{2} \\
25=5^{2} & 36=6^{2} & 49=7^{2} & 64=8^{2}
\end{array} \ldots
$$

A esse respeito, pode-se notar também ser possível determinar a raiz quadrada de cada um desses números:

$$
\begin{aligned}
& \sqrt{1}=1 \\
& \sqrt{4}=\sqrt{1+3}=2 \\
& \sqrt{9}=\sqrt{1+3+5}=3 \\
& \sqrt{16}=\sqrt{1+3+5+7}=4 \\
& \sqrt{25}=\sqrt{1+3+5+7+9}=5 \\
& \sqrt{36}=\sqrt{1+3+5+7+9+11}=6 \\
& \sqrt{49}=\sqrt{1+3+5+7+9+11+13}=7
\end{aligned}
$$

Em discussões posteriores, realizaremos considerações complementares sobre os números quadrados. Sequencialmente, vamos abordar ideias relativas aos números pentagonais. 
Os números pentagonais, como o próprio nome sugere, são representados como uma figura plana que assume a forma de um pentágono equilateral. Como exemplos, temos: 1, 5, 12,22,35, 51,70 e assim por diante. Considerando-se 5 como o primeiro número pentagonal listado, encontramos 2, como o lado desse pentágono; 3 representa o lado do segundo número pentagonal, representado por 12; 4 é o lado da próxima figura, dada pelo 22; 5, o lado da figura que sucede $22 \mathrm{e}$, assim, sucessivamente.

Nicômaco descreve que, de modo geral, cada lado da figura contém tantas unidades quanto os números que foram adicionados para se formar o pentágono indicado, e é a série aritmética natural estabelecida em uma linha que irá definir essa formação.

A unidade representa, potencialmente, o primeiro pentágono. Já o 5, formado pela combinação de 1 mais 4, representa o segundo; 12 indica o terceiro, o qual se constitui da adição de 7 à figura anterior, sendo que 3 corresponde ao seu lado. Veja as representações a seguir (Quadro 3):

Quadro 3-Os números pentagonais

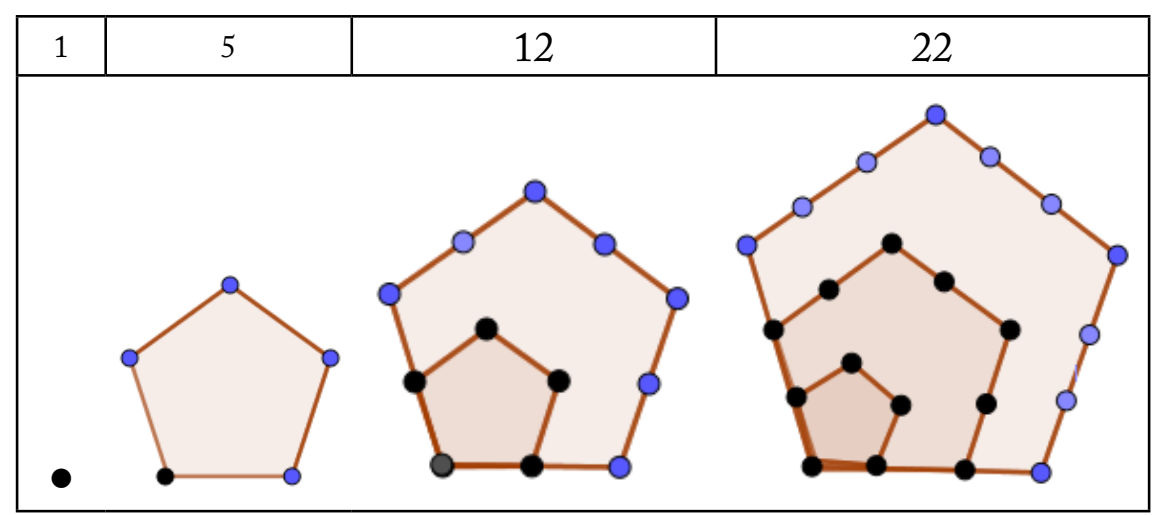

Fonte: Elaborado pela autora

A formação dos demais números pentagonais ocorre de modo que sejam adicionadas unidades, uma após a outra, dadas pela diferença de 3 unidades. Observe (Tabela 1): 
Tabela 1 - A formação dos números pentagonais

\begin{tabular}{c|l}
\hline Número pentagonal & \multicolumn{1}{c}{ Formação } \\
\hline 1 & 1 \\
\hline 5 & $1+4$ \\
\hline 12 & $1+4+7$ \\
\hline 22 & $1+4+7+10$ \\
\hline 51 & $1+4+7+10+13$ \\
\hline 70 & $1+4+7+10+13+16$ \\
\hline 92 & $1+4+7+10+13+16+19$ \\
\hline 117 & $1+4+7+10+13+16+19+22$ \\
\hline
\end{tabular}

Fonte: Elaborado pela autora

Essa configuração, representada na Tabela 1, mostra o que destacamos anteriormente, por meio de figuras. Após o 1, os próximos números pentagonais são gerados pela união de outros pontos. Como exemplo, destacamos a quarta representação, dada pelo número 22. Para formá-lo, foi colocado primeiro um ponto e, posteriormente, quatro, depois sete e, por último, dez pontos. As figuras posteriores seguiriam lógicas similares, conforme indicamos na Tabela 1 . Vejamos na sequência como ocorre a formação dos próximos números figurados.

\section{Os números figurados posteriores}

Os próximos números figurados, como os hexagonais e os heptagonais, por exemplo, são apresentados em séries que seguem o mesmo processo. Pode-se perceber que, em cada número triangular produzido pela admissão na soma, por exemplo, os números diferem em 1 e não passam sobre nenhuma série. No caso dos números quadrados, sua formação foi feita adicionando-se os termos que diferem em 2 unidades e há separação entre elas. Com o pentágono ocorre de modo semelhante, e são adicionados termos semelhantes com uma diferença de 3, separando-se dois lugares. Seguindo essa mesma lógica, Nicômaco descreve que a formação dos números hexagonais possui, como números base, aqueles que diferem 
de 4 e são separados por três lugares na série e, ao serem somados, de modo sucessivo, produzem os hexágonos. Nesse sentido, a sequência 1, 5, 9, 13, 17,21 , e assim sucessivamente, produz os números hexagonais $1,6,15,28$, 45, 66, e assim por diante.

No caso dos heptágonos, os processos são análogos, o que resulta na formação dos números heptagonais $1,7,18,34,55,81,112,148$, dentre outros.

A sequência que embasa a formação dos números octogonais respeita uma diferença de 6 unidades e, conforme a obra analisada, essa variação é observada na constituição total do número descrito. Pode-se verificar que há uma regra que constitui a formação dos números figurados. Os números raízes ou números bases de qualquer polígono diferem em 2 unidades a menos que o número de ângulos do polígono analisado. Por exemplo, no triângulo, que possui três ângulos, a sequência raiz difere em 1 unidade, que é dada por 1; no quadrado, essa diferença é 2 unidades; no pentágono, 3 unidades; de 4, no hexágono; 5, no heptágono, e assim por diante; esse aumento sempre ocorre de forma semelhante. Observe:

Tabela 2 - A formação das sequências

\begin{tabular}{l|l|l}
\hline Números & Número raiz & Sequência base formada \\
\hline Triangulares & $3-2=1$ & $1,2,3,4,5,6,7,8, \ldots$ \\
\hline Quadrados & $4-2=2$ & $1,3,5,7,9,11,13, \ldots$ \\
\hline Pentagonais & $5-2=3$ & $1,4,7,10,13,16,19, \ldots$ \\
\hline Hexagonais & $6-2=4$ & $1,5,9,13,17,21,25, \ldots$ \\
\hline Heptagonais & $7-2=5$ & $1,6,11,16,21,26, \ldots$ \\
\hline Octogonais & $8-2=6$ & $1,7,13,19,25,31, \ldots$ \\
\hline
\end{tabular}

Fonte: Elaborado pela autora

Pode-se notar que, para dar continuidade à formação da Tabela 2, seguindo a regra referente à descoberta do número raiz, é possível obter, então, a sequência base que forma os próximos números figurados. Seguem, na seção posterior, mais algumas considerações a respeito da construção desses números. 
Algumas considerações em relação à formação dos números figurados podem ser ampliadas. Nicômaco observa, por exemplo, que cada figura quadrada, ao ser dividida de modo diagonal, forma dois triângulos sucessivos. Como se pode identificar, 1, 3, 10, 15, 21, 28, 36, 45 ... representam os números triangulares, e 1, 4, 9, 16, 25, 36, ... dizem respeito aos números quadrados. Sendo assim, ao acrescentar dois triângulos consecutivos, sempre teremos um quadrado, e desse podem-se obter dois triângulos.

Se ocorrer a união de um triângulo com um quadrado, temos a formação de um pentágono. A figura triangular 1 , ao ser unida ao quadrado 4, constitui o pentágono 5; o próximo triângulo, representado por 3 , ao ser associado a 9, que é o quadrado posterior, forma o pentágono 12; já o próximo, 6 , adicionado ao quadrado 16 , gera o próximo pentágono que é 22 ; logo, a adição de 10 e 35, gera 35; e assim sucessivamente.

Segundo a obra Introdução à Aritmética, se os triângulos forem adicionados aos pentágonos, respeitando procedimentos análogos ao anterior, hexágonos serão formados e, novamente, os mesmos triângulos, ao serem adicionados a esses últimos, formarão heptágonos em ordem, e os octogonais serão formados após os heptagonais e assim por diante, até onde se queira ampliar.

Observe a sucessão dos números figurados:

Tabela 3 - A sucessão dos números figurados

\begin{tabular}{l|c|c|c|c|c|c|c|c|c|c}
\hline Triangulares & 1 & 3 & 6 & 10 & 15 & 21 & 28 & 36 & 45 & 55 \\
\hline Quadrados & 1 & 4 & 9 & 16 & 25 & 36 & 49 & 64 & 81 & 100 \\
\hline Pentagonais & 1 & 5 & 12 & 22 & 35 & 51 & 70 & 92 & 117 & 145 \\
\hline Hexagonais & 1 & 6 & 15 & 28 & 45 & 66 & 91 & 120 & 153 & 190 \\
\hline Heptagonais & 1 & 7 & 18 & 34 & 55 & 81 & 112 & 148 & 189 & 235 \\
\hline
\end{tabular}

Fonte: NICÔMACO (1926) 
Ao analisar a Tabela 3, é possível perceber que os quadrados podem ser obtidos por meio da soma dos triângulos que ocupam o mesmo lugar da série. Veja:

- O quadrado 16 é formado pela união dos triangulares 10 e 6;

- O quadrado 81 constitui-se pela união dos triangulares 45 e 36;

E assim por diante.

A formação dos pentágonos também respeita uma regra, o que pode ser verificado na Tabela 3. A soma dos quadrados que estão acima deles, no mesmo lugar da série, adicionados aos triângulos elementares que estão em uma posição anterior à série considerada, ou seja:

- O pentágono 5 forma-se pela soma dos quadrados 4 mais o triângulo 1 ;

- O pentágono 22 é formado pela união do quadrado 16 mais o triângulo 6 (que está na posição anterior à série analisada);

- O pentágono 70 forma-se pela união do quadrado 49 mais o triângulo 21;

- O pentágono 145 forma-se pela união de 100 com 45, os quais representam, respectivamente, o quadrado e o triângulo.

E assim sucessivamente.

De modo similar, os hexágonos são formados, respeitando-se a soma entre o pentágono que está na posição acima, na mesma série, e o triângulo que ocupa a posição anterior à série analisada. Observe:

- O hexágono 15 constitui-se da união do pentágono 12 e do triângulo 3;

- O hexágono 28 constitui-se da união do pentágono 28 e do triângulo 6;

E assim por diante.

Com isso, nota-se que o triângulo é um elemento essencial desses polígonos, tanto em figuras quanto em números. 


\section{As representações atuais dos números figurados}

Mediante as explanações realizadas, pode-se observar como a constituição dos números figurados estava associada aos aspectos geométricos e à formação de sequências numéricas.

Reiteramos o que Roque (2012, p. 104) pontua: "os números figurados dos pitagóricos eram constituídos de uma multiplicidade de pontos que não eram matemáticos e que remetiam a elementos discretos”. Ou seja, a linguagem dos pitagóricos designava cada combinação de modo distinto, com ligações particulares.

Nos dias atuais, no ensino regular, o estudo dos números figurados continua sendo importante. Roque (2012), por exemplo, descreve que a sequência dos números triangulares $1,3,6,10,15$ e 21, de ordem $n=1,2,3$, 4, 5 e 6, está associada ao estudo atual de progressão aritmética, comumente abordada na primeira série do Ensino Médio, em escolas de Educação Básica. Segundo a autora, esse número triangular de ordem $n$ é dado por:

$$
1+2+3+\cdots+n=\frac{n(n+1)}{2} \text {. }
$$

No caso dos números quadrados, algebricamente, a configuração de $1,4,9,16=1^{2}, 2^{2}, 3^{2}, 4^{2}$, por exemplo, é dada por $n^{2}$, o que é válido para os próximos termos da sequência.

A formação das configurações dos números figurados que geram essas sequências, de acordo com o ponto de vista dos pitagóricos, estava ligada às observações visuais e era bem distinta da aritmética que é praticada hoje. Roque (2012) destaca que os pitagóricos tiravam diversas conclusões aritméticas, por meio da visualização. A esse respeito, pode-se mencionar a afirmação de que todo número quadrado corresponde à soma de dois números triangulares sucessivos, o que pode ser descrito, atualmente, pela relação:

$$
n=\frac{n(n+1)}{2}+\frac{(n-1) n}{2}
$$

Baron (1985) também reforça o quanto a escola pitagórica teve importância na interpretação de uma figura como um numeral. De modo 
análogo a Roque (2012), a autora observa que os pitagóricos usavam a ideia de gnomon ${ }^{7}$ o que corresponde à "porção da fronteira dos números quadrados e retangulares nos dois lados em forma de L" (BARON, 1985, p.17). Observe a Figura 2:

Figura 2 - Números quadrados e retangulares

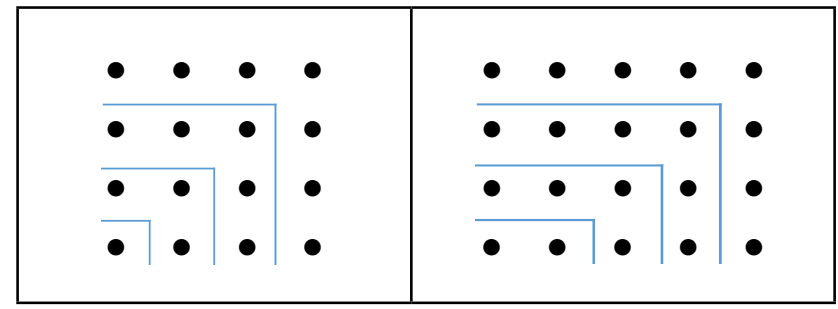

Fonte: Elaborada pela autora

Oliveira (2010), em seu trabalho, também faz referência às interpretações da Figura 2. Segundo ele, a prática de representar os números através de um agrupamento de unidades, por meio de bolinhas, era algo recorrente para os membros da escola pitagórica. As marcas ou traços na forma de gnomon geravam figuras geométricas.

Quando a série dos números ímpares era colocada ao redor de uma unidade na forma de gnomon, o resultado era sempre uma figura quadrada, portanto permanece sempre a 'mesma'. Quando a série de números pares era colocada da mesma maneira, a relação entre os lados das figuras geradas (retângulos) era sempre diferente (OLIVEIRA, 2010, p. 59).

$\mathrm{Na}$ linguagem moderna, essas representações, indicadas na Figura 3, podem ser interpretadas, respectivamente, pelas seguintes relações:

$$
\begin{aligned}
& 1+3+5+7+\cdots+(2 n-1)=n^{2} \\
& 2+4+6+8+\cdots+2 n=n(n+1)
\end{aligned}
$$

\footnotetext{
${ }^{7}$ Segundo Baron (1985, p.17), "um gnomon tinha originalmente a forma retangular sombreada ao longo da superfície de um relógio solar". A autora ressalta que, depois de certo tempo, essa palavra foi associada ao significado de perpendicularidade, e seu uso estendeu-se para descrever alguns instrumentos utilizados para traçar ângulos retos, como o esquadro de um carpinteiro.
} 
Ou ainda, pode-se verificar que:

$$
\begin{aligned}
1^{2}+3 & =2^{2} \\
2^{2}+5 & =3^{2} \\
3^{2}+7 & =4^{2} \\
\cdots & \\
n^{2}+(2 n+1) & =(n+1)^{2}
\end{aligned}
$$

Esses são alguns exemplos de interpretações que poderiam ser realizadas sobre números figurados no contexto do ensino brasileiro, utilizando-se embasamentos históricos referentes ao pitagorismo, em especial quando se trata da formação de professores de Matemática.

Possíveis enfoques relativos ao contexto da escola pitagórica e aos números figurados podem encaminhar visões distintas, contribuindo com a compreensão de abordagens atuais:

É possível distinguir pelo menos três funções diferentes para essas entidades, sobre as quais as doutrinas pitagóricas foram construídas: designavam posição ou ordem; determinavam uma forma espacial (números figurados); e, finalmente, exprimiam razões distintas que permitiam compreender as leis naturais (ROQUE, 2012, p. 108).

Embora diversas questões ligadas à compreensão de leis naturais não sejam conectadas com a matemática em nossa realidade, como ocorria com os pitagóricos, ainda assim prevalecem aspectos direcionados à ordem, à formação de sequência e ao uso de figuras, e tais ideias podem ser exploradas no contexto acadêmico.

A fim de exemplificar interpretações e utilização dos números figurados na educação básica, vamos utilizar um recorte da proposta curricular de matemática e suas tecnologias, elaborados pela Secretaria de Educação do Estado de São Paulo ${ }^{8}$ (SÃO PAULO, 2011). Para analisá-lo, segue o Quadro 4:

\footnotetext{
${ }^{8}$ Isso porque a autora já lecionou neste Estado e o programa serviu como base para as referências aqui mencionadas.
} 
Quadro 4- Conteúdos e habilidades na 1a série do Ensino Médio

\begin{tabular}{|l|l|}
\hline Conteúdos -1 o bimestre & Habilidades \\
\hline Números e sequências: & - Saber reconhecer padrões e regularidades em \\
- Conjuntos numéricos & sequências numéricasoudeimagens,expressando-as, \\
- Regularidades numéricas & sempre que possível, matematicamente. \\
por meio da abordagem de & - Conhecer as características principais das \\
sequências & progressões aritméticas e geométricas, como: termo \\
- Progressões aritméticas e & geral, soma dos n primeiros termos, entre outras. \\
progressões geométricas & - Saber aplicar o estudo de progressões, aritmética e \\
& geométrica, em diferentes contextos. \\
& - Compreender o significado da soma dos termos de \\
& uma PG infinita (razão de valor absoluto menor \\
& que 1) e saber calcular a soma em alguns contextos, \\
& físicos ou geométricos. \\
\hline
\end{tabular}

Fonte: Elaborado pela autora

Por meio do Quadro 4, podemos observar a relevância do estudo de padrões e regularidades acerca de sequências numéricas e figuras. É possível verificar como tal tema é aplicado ao estudo de progressões e ao uso de generalizações, tudo já no início do Ensino Médio. É importante salientar que o conhecimento dessa temática é exigido em diferentes avaliações externas, associadas aos conteúdos vistos na Educação Básica. Tomemos como exemplos questões da Olimpíada Brasileira de Matemática das Escolas Públicas $(\mathrm{OBMEP})^{9}$ e uma questão do Exame Nacional do Ensino Médio $(\mathrm{ENEM})^{10}$. Vejamos três questões (1,2 e 3$)$ relacionadas com essas avaliações:

\footnotetext{
${ }_{9}^{9}$ De acordo com o novo regulamento que consta no site da OBMEP (http://www.obmep. org.br/regulamento.htm), essa olimpíada, a partir de 2017, também será direcionada a estudantes de escolas privadas. Segundo as normas, podem participar alunos do $6^{\circ}$ ao $9^{\circ}$ ano do Ensino Fundamental e alunos do Ensino Médio, de Escolas Públicas municipais, estaduais e federais, e Escolas Privadas, bem como aos respectivos professores, escolas e secretarias de educação.

${ }^{10} \mathrm{O}$ Enem foi criado em 1998 e tem como objetivo avaliar o desempenho dos alunos ao final da escolaridade básica. Atualmente, o Enem vem sendo utilizado como critério de seleção para o ingresso em diferentes universidades e também na concorrência de bolsas de estudos, como o Programa Universidade para Todos (ProUni).
} 
Questão 1 - Essa questão refere-se ao Banco de Questões da OBMEP (2010) e será apresentada no Quadro 5.

\section{Quadro 5- Questão da OBMEP}

O famoso matemático grego Pitágoras chamou de números triangulares os números obtidos pela soma dos primeiros números inteiros maiores que 0 . Por exemplo, 1, 3, 6 e 10 são números triangulares:

$1=1$

$3=1+2$

$6=1+2+3$

$10=1+2+3+4$

A Figura 3 ilustra a motivação para a utilização do nome números triangulares.

Figura 3: A sequência que deu origem aos números triangulares

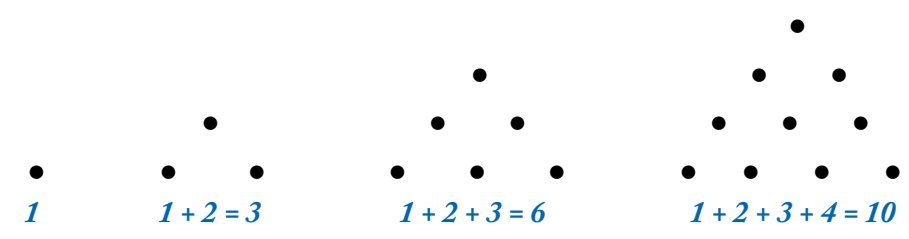

A sequência de números triangulares continua com $1+2+3+4+5=15$, $1+2+3+4+5+6=21$, etc.

Quantos são os números triangulares menores do que 100?

Fonte: Elaborada pela autora a partir da OBMEP (2010)

Questão 2 - Essa questão será apresentada no Quadro 6.

\section{Quadro 6- Questão da OBMEP}

Sobre uma superfície plana são dispostos palitos iguais formando figuras, como mostrado na Figura 4.

Figura 4 - Formação de figuras com palitos
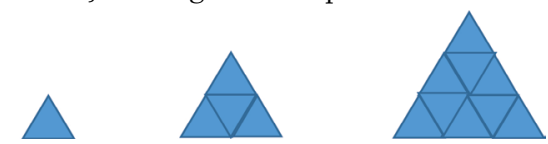

Contando os palitos de cada uma dessas figuras e denotando por $\mathrm{a}_{\mathrm{n}} \mathrm{o}$ número de palitos da n-ésima figura, encontra-se:

$a_{1}=3$,

$\mathrm{a}_{2}=9$,

$\mathrm{a}_{3}=18, \ldots$

Determine, nesse caso, o valor de a 100 .

Fonte: Elaborada pela autora a partir de OBMEP (2006) 


\section{Quadro 7- Questão do ENEM}

Ronaldo é um garoto que adora brincar com números. Numa dessas brincadeiras, empilhou caixas numeradas de acordo com a sequência conforme mostrada no esquema a seguir.

$\begin{array}{llllllll} & & & & 1 & & & \\ & & & 1 & 2 & 1 & & \\ & & & & & & & \\ & 1 & 2 & 3 & 2 & 1 & \\ & 2 & 3 & 4 & 3 & 2 & 1\end{array}$

Ele percebeu que a soma dos números em cada linha tinha uma propriedade e que, por meio dessa propriedade, era possível prever a soma de qualquer linha posterior às já construídas.

A partir dessa propriedade, qual será a soma da ${ }^{a}$ linha da sequência de caixas empilhadas por Ronaldo?
a) 9
b) 45
c) 64
d) 81
e) 205

Fonte: Elaborada pela autora a partir do BRASIL (2010).

Todos esses exemplos de questões, expostas nos quadros 5, 6 e 7, retratam como diferentes abordagens relacionadas ao estudo dos números figurados podem se apresentar no contexto de avaliações atuais. As duas primeiras questões fazem parte de um banco de questões preparatórias para a OBMEP. Nelas, encontramos algumas referências ligadas, direta ou indiretamente, ao modo como a configuração desses números tem se apresentado. Particularmente, a segunda questão não questiona, de forma objetiva, padrões de sequências, como aqui foi explorado; no entanto, pode-se observar por meio da imagem que tal disposição dos palitos envolve uma sequência de pontos caracterizada por $3,6,10, \ldots$, fato que está diretamente relacionado à união dos palitos e, intuitivamente, à configuração realizada na Figura 3, do Quadro 5.

A terceira questão (Quadro 7), retirada de uma das provas do ENEM, explora conhecimentos sobre o estudo de sequências numéricas, as quais estão associadas ao entendimento de números quadrados. 
Esses exemplos ilustram a relevância da compreensão de números figurados em nossa realidade educacional. Chiconello (2013) observa que os livros didáticos abordam pouco ou quase nada o estudo de temas ligados a números figurados e sequências numéricas. Nas palavras do autor, no contexto brasileiro, esses materiais se restringem à explanação de progressões aritmética e geométrica, bem como raras aplicações, as quais são feitas através da manipulação de alguns exercícios ou problemas.

Dessa forma, em consonância com esse autor, ressaltamos que há escassez de temáticas que envolvem os números figurados, tanto na Educação Básica como nas universidades. Por isso, a contribuição deste trabalho volta-se também à formação de professores que lecionam Matemática, em especial no que tange conhecimentos referentes à História da Matemática.

\section{Considerações finais}

Este capítulo buscou resgatar conhecimentos a respeito dos números figurados a partir de bases históricas fundamentais. Seus referenciais tiveram como intenção propiciar visões gerais acerca da origem desses números, amparadas, principalmente, em princípios pitagóricos, e foram se ampliando até chegar a suas compreensões atuais.

As primeiras reflexões traçaram ideias sobre a formação do universo, a criação de lendas e misticismo, e a compreensão dos números do ponto de vista da escola pitagórica. Posteriormente, por meio de fontes históricas distintas, houve a necessidade de relacionar fundamentações básicas de números com a aritmética e a geometria, tanto é que, na sequência, Nicômaco de Gerasa foi destacado como o compilador da obra mais completa que trata dos números figurados.

Sendo assim, uma descrição dos números figurados planos foi realizada com o intuito de detalhar as ideias pertinentes às suas formações e composições. Esse detalhamento mobilizou reflexões acerca do uso e de aplicações dos números figurados nos tempos atuais. Nesse sentido, percebe-se que esses números se fazem bem presentes em grades curriculares da Educação Básica, notando-se, também, que diferentes avaliações retratam 
como essa temática é relevante. Se tudo isso ainda o é, faz-se necessário refletir sobre os motivos que levam à pouca abordagem desse assunto nas salas de aula, do ensino regular à educação universitária.

Atualmente, não encontramos muitos referenciais acadêmicos que tratam do ensino ou da aprendizagem dos números figurados, mesmo observando-se ser um tema frequente em determinadas avaliações. Há menores índices, ainda, de estudos que o explanam sob as perspectivas da História da Matemática.

Dessa forma, nesse estudo, buscamos compilar uma abordagem geral, das bases originárias a algumas concepções atuais, de como tais números podem se apresentar, de modo que reflexões acerca desse conhecimento possam emergir, principalmente quando se trata da formação e atuação do professor de Matemática no ensino regular. O pitagorismo não ficou no passado, ele está e se faz presente em diferentes linguagens, em distintas visões. Contemplá-lo sob a interpretação dos números figurados é uma das infinitas possibilidades de ver como essas configurações podem ser arranjadas em contextos e momentos variados.

\section{Referências}

BARON, M. E. Curso de história da matemática: origens e desenvolvimento do cálculo. Tradução de José Raimundo Braga Coelho, Rudolf Maier e Maria José M. M. Mendes. Brasília: Editora Universidade de Brasília, 1985.

BOYER, C. B. História da matemática: tradução: Elza F. Gomide. São Paulo: Editora da Universidade de São Paulo, 1974.

BRASIL. Ministério da Educação. Instituto Nacional de Estudos e Pesquisas Educacionais Anísio Teixeira. Exame Nacional do Ensino Médio. Brasília, DF, 2010. Disponível em: <http://download.inep.gov.br/educacao_basica/enem/provas/2010/AZUL_Domingo_GAB.pdf>. Acesso em: 22 dez. 2017.

BRITO, A. de J. Matemática na Idade Média: entre o místico e o científico. Revista Brasileira de História da Matemática Especial, especial n. 1, p. 127-141, 2007. Disponível em: <http://rbhm.org.br/issues/RBHM\%20-\%20Festschrift/13\%20-\%20Arlete\%20-\%20final. pdf>. Acesso em: 2 nov. 2017.

BRITO, A. J. B. O Quadrivium na obra de Isidoro de Sevilha. 1999. 150f. Tese (Doutorado em Educação) - Faculdade de Educação, Universidade Estadual de Campinas, 1999. 
CHICONELLO, L. A. Números figurados e as sequências recursivas: uma atividade didática envolvendo números triangulares e quadrados. 2013. 86f. Dissertação (Mestrado Profissional) - Universidade Federal de São Carlos, 2013.

DUARTE, C. L.; GONÇALVES, H. H.; NÓBREGA, N. P. Tudo é número: uma análise conceitual da ideia de número em Pitágoras. Revista Principia, João Pessoa, n. 33, p. 99 107, maio, 2017.

NICÔMACO. Introduction to Arithmetic. Translated into English by Martin L. D'Ooge. NY: Macmillam Company, 1926.

OBMEP. OLIMPÍADA BRASILEIRA DE MATEMÁTICA DAS ESCOLAS PÚBLICAS. 2006. Disponível em: < http://www.obmep.org.br/bq/bq2006.pdf >. Acesso em: 16 dez. 2017.

OBMEP. OLIMPÍADA BRASILEIRA DE MATEMÁTICA DAS ESCOLAS PÚBLICAS. 2010. Disponível em: <http://www.obmep.org.br/bq/bq2010.pdf>. Acesso em: 16 dez. 2017.

OLIVEIRA, G. M. Os princípios cosmológicos de Filolau e a música. 2010. 101f. Dissertação (Mestrado em Filosofia) - Pontifícia Universidade Católica de São Paulo, São Paulo, 2010.

ROQUE, T. História da matemática: uma visão crítica, desfazendo mitos e lendas. Rio de Janeiro: Zahar, 2012.

SANTOS, M. F. dos. Pitágoras e o tema do número. São Paulo: IBRASA, 2000.

SÃO PAULO. Ministério da Educação. Secretaria da Educação. Currículo do Estado de São Paulo: Matemática e suas tecnologias. São Paulo: SE, 2011. 72 p.

SZABÓ, A. The beginnings of Greek mathematics. Translation of Anfänge griechischen Mathematik. Budapest: Akadémiai Kiadó, 1978 


\section{OS PITAGÓRICOS EM LIVROS \\ TEXTOS DA IDADE MODERNA}

Arlete de Jesus Brito

Nos meios escolares, aprendemos a conectar automaticamente o nome de "Pitágoras", ao famoso "teorema” e à "matemática”. Tal conexão está relacionada a uma tradição escolar difundida, principalmente, pelos livros didáticos de matemática. Como veremos neste texto, essa tradição remonta às mudanças sociais ocorridas no início da Idade Moderna, como, por exemplo, a invenção da imprensa que possibilitou o mercado de livros didáticos, à ascensão da classe burguesa e à importância que ela conferia ao trabalho.

Conforme podemos observar pelos testemunhos que temos sobre eles em obras antigas, como, por exemplo, no texto Vida Pitagórica, escrito por Jâmblico (245-325), a atuação de Pitágoras e de seus seguidores, na Antiguidade, ia muito além da matemática. Nesse livro, o autor aponta para a atuação política, religiosa e filosófica dos pitagóricos e apresenta ao leitor uma extensa lista de nomes de membros da comunidade - ou seita, como denomina Cornelli (2010) - pitagórica, dentre os quais podemos verificar a participação de 17 mulheres. Porém, como observa Jâmblico, é provável que o nome de muitos outros membros nos sejam desconhecidos.

Pela lista de nomes de pitagóricos encontrada no Vida Pitagórica, percebemos que o pitagorismo se disseminava por diversas cidades gregas, como, por exemplo, Crotona, Metaponto, Eléa, Tarento, Síbaris, Cartagena, Siracusa, Cirene, Corinto, Atenas ${ }^{1}$ etc. Nessas regiões, os pitagóricos difundiam um ideal de vida ascética, pregavam a imortalidade e reencarnação da alma, defendiam o vegetarianismo e a comunhão entre amigos. Ao ser aceito na comunidade pitagórica, o novo membro partilhava todos os seus bens com os demais membros, o que significava que suas posses materiais

\footnotetext{
${ }^{1}$ A Grécia antiga abrangia várias cidades que atualmente pertencem a outros países, como, por exemplo, Siracusa, situada na Itália.
} 
não pertenceriam mais à família do recém-admitido na comunidade de sábios. É provável que esse seja um dos motivos para que parte das pessoas dos locais em que os pitagóricos se instalavam os rechaçasse e até mesmo os perseguisse (cf. JÂMBLICO, 1818; CORNELLI, 2010).

Apesar disso, os ideais pitagóricos resistiram por séculos, para além da sociedade grega da Antiguidade e Platão (sec. IV a.C.), teve papel importante para a difusão de tais ideias, inclusive por meio de textos que descrevem diálogos supostamente ocorridos entre Sócrates e pitagóricos como Timeu e Menon². Por exemplo, em Timeu é exposto um modo de se compreender a formação do universo embasada na forma e no número. Segundo esse texto, a partir da sequência 1,2,3, 4, 8, 9 e 27, teriam sido formadas notas musicais que seriam inerentes aos astros celestes. $\mathrm{O}$ conjunto dos sons de todos os astros era o que se denominava por "harmonia das esferas”. Timeu e outros escritos de Platão foram utilizados pela filosofia cristã tanto na Antiguidade Tardia, quanto nos primeiros séculos da Idade Média, como se pode observar pela obra de Santo Agostinho (sec. IV) e a de Isidoro de Sevilha (sec. VII).

No entanto, conforme aponta Cornelli (2010) deve-se considerar que a noção de "pitagorismo" é construída historicamente. Ou seja, trata-se de uma categoria histórica, elaborada por meio dos diversos textos sobre aqueles filósofos gregos, em diferentes épocas, tiveram e têm a sua disposição, e pelo modo como tais textos são socialmente interpretados. Assim, por exemplo, Zeller, em seu livro de 1855 (cf. CORNELLI, 2010), considerava como fonte privilegiada sobre os pitagóricos a obra de Aristóteles (sec. IV a. C.). Por meio da leitura positivista que fez dela, divulga, no século XIX, a famosa asserção que os pitagóricos defendiam: "tudo é número".

\footnotetext{
${ }^{2}$ Segundo o catálogo de nome de pitagóricos, inserido no livro de Jâmblico (1818), Timeu e Menon foram pitagóricos provenientes de Crotona e viveram no séc. IV a.C.

3 Para maiores detalhes sobre a teoria musical pitagórica, sugerimos o capítulo de Carla Patrícia Ferreira dos Santos, neste livro.
} 
Considera também os textos de Filolau ${ }^{4}$ e, devido a isso, cita a doutrina pitagórica da harmonia, do fogo central e da teoria das esferas. Coloca-se contra a ideia de que o pitagorismo teria raízes nas filosofias orientais e despreza a dimensão política da Koinonía (comunhão) pitagórica. Também de matiz positivista, já no início do século XX, seria o texto de Diels (cf. CORNELLI, 2010) que realiza a crítica sobre a historiografia anterior acerca da atuação daqueles filósofos antigos. Diels utiliza o catálogo dos pitagóricos encontrado em Jâmblico e, como Zeller, exclui de sua versão histórica a atividade política e religiosa dos seguidores de Pitágoras.

Com o advento da História Nova, obras de outros historiadores, como as de Cornford (1922) e de Minar (1942), buscaram integrar política, religião e ciência em suas versões sobre a comunidade pitagórica (cf. CORNELLI, 2010). Para Cornelli (2010), haveria um modo de viver, ou seja, um bios pitagórico baseado na comunhão de bens, na teoria da imortalidade da alma (metempsicose), no desenvolvimento de teorias matemáticas e no uso destas para uma explicação do funcionamento do universo. É necessário ressaltar que, para aqueles filósofos gregos, a aritmética, a geometria, a música e a astronomia faziam parte de um mesmo corpo de conhecimentos, conhecido durante a Idade Média, como quadrivium. A aritmética seria o estudo dos números em repouso, a música, dos números em movimento, enquanto a geometria seria o conhecimento das formas em repouso, e a astronomia, das formas em movimento.

Algo observável é como a quantidade de textos acerca dos pitagóricos se multiplica, no decorrer da história. Zeller (cf. CORNELLI, 2010) observa que, com o passar dos tempos, as fontes sobre os pitagóricos, ao invés de diminuírem, aumentaram, e aponta neopitagóricos, como Nicômaco de Gerasa (sec. I), Porfírio (sec. IV) e Jâmblico, como personagens fundamentais para que isso ocorresse e também para a construção e difusão de um conceito de "pitagóricos".

\footnotetext{
${ }^{4}$ Filolau de Crotona foi pitagórico e viveu entre os séculos V e IV a. C. Defendia que a Terra estaria em movimento ao redor de um fogo central, que não seria o Sol, mas um astro não visível pelo lado habitado da Terra. Entre tal fogo central e a Terra haveria uma antiterra. Assim, juntamente com o Sol, a Lua, Mercúrio, Vênus, Marte, Júpiter e Saturno, o número de corpos celestes seria dez, número que os pitagóricos consideravam perfeito.
} 
O neopitagorismo floresceu em Alexandria entre os séculos I a.C. e IV d.C. Compunha-se por um misticismo numérico pitagórico, pelo estoicismo $^{5}$, pela aceitação de alguns pontos do aristotelismo e por uma releitura das ideias platônicas. Nicômaco, em sua Aritmética, realizou uma exposição sobre a composição das "coisas" baseada na junção das ideias platônicas com um misticismo numérico, segundo o qual, tudo no mundo teria uma fundamentação numérica. Conforme Nicômaco:

\begin{abstract}
Algumas das coisas, então - ambas, aquelas assim propriamente chamadas [a essência] e aquelas que simplesmente têm o nome [as que existem no mundo sensível] - são unificadas e contínuas, por exemplo, um animal, o universo, uma árvore, etc., que são propriamente e peculiarmente chamadas de "magnitudes"; outras são descontínuas, lado a lado organizadas e quando acumuladas são denominadas "multitudes", como uma pessoa, um coro, etc. Sabedoria, então, deve ser considerada o conhecimento dessas duas formas (NICÔMACO, 1926, p. 183, tradução nossa) ${ }^{6}$.

Tudo na natureza que tem sido arranjado por um método sistemático no Universo parece em ambos, tanto em suas partes como no todo, ter sido determinado e ordenado de acordo com o número, pela previsão e mente daquele que criou todas as coisas; por um padrão que foi fixado, como um rascunho preliminar, pelo domínio do número preexistente na mente do criador do mundo, Deus (NICÔMACO, 1926, p. 189)7 .
\end{abstract}

\footnotetext{
${ }^{5} \mathrm{O}$ estoicismo foi uma escola filosófica grega fundada por Zenão de Cício. Era um sistema integrado pela lógica, pela física e pela ética, mas foi essa última que teve maior influência na tradição filosófica, inclusive na cristã. O ideal dessa filosofia seria o viver em harmonia com a natureza, dominando as paixões e suportando sofrimentos até atingir a completa indiferença perante os acontecimentos. (JAPIASSÚ; MARCONDES, 1996).

${ }^{6}$ Things, then, both those properly so called and those that simply have the name, are some of them unified and continuous, for example, an animal, the universe, a tree, and the like, which are properly and peculiarly called 'magnitudes'; others are discontinuous, in a side by-side arrangement, and, as it were, in heaps, which are called 'multitudes,' a flock, for instance, a people, a heap, a chorus, and the like. Wisdom, then, must be considered the knowledge of this two forms. (NICÔMACO, 1926, p. 183)

${ }^{7}$ All that has by nature with systematic method been arranged in the universe seems both in part and as a whole to have been determined and ordered in accordance with number, by the forethought and the mind of him that created all things ; for the pattern was fixed, like a preliminary sketch, by the domination of number preexistent in the mind of the world-creating God (NICÔMACO, 1926, p. 189)
} 
Para Nicômaco, assim como para os primeiros pitagóricos, a aritmética não seria um estudo de cômputos numéricos ${ }^{8}$, mas uma parte da filosofia voltada ao estudo das propriedades e relações numéricas. A ela estaria subordinado o estudo da música, das formas (geometria) e dos corpos celestes (astronomia). Assim, no livro I, da obra Aritmética, esse neopitagórico expõe os conceitos, classificações e propriedades dos números. No livro II, a geometria nos é apresentada de um ponto de vista aritmético, por meio dos números figurados e das relações entre eles.

Após Nicômaco, pensadores como Porfírio e Jâmblico, tanto quanto Santo Agostinho, amalgamaram o neopitagorismo e o neoplatonismo, de modo a formar a filosofia de base verificada em textos cristãos, durante a maior parte da Idade Média. Esses conhecimentos serviram de contraponto aos dogmas da escolástica, já no início da Idade Moderna, quando o advento da imprensa, o acesso aos textos gregos antigos, tanto em suas traduções árabes quanto latinas, e um novo modo de organização econômica e social possibilitaram a pessoas da Europa, em inícios da Idade Moderna, o acesso a conhecimentos da Antiguidade. Assim, verificamos em obras de vários pensadores modernos a referência a conceitos ligados ao pitagorismo. Vejamos alguns exemplos de textos do século XVII, em que se encontram noções pitagóricas.

René Descartes (1596-1650), em carta enviada para o orientalista e matemático Jacob Golius ${ }^{9}$ (1596-1667), escrita em 16 de abril de 1635, refere-se à teoria da metempsicose e da reminiscência socrática. Leibniz (1646-1716), já no final do século XVII, toma emprestado dos pitagóricos a ideia de mônada. Galileu Galilei (1564-1642) em O Ensaiador (1623) nos relata que seu oponente, Sr. Sarsi, teria utilizado a autoridade dos pitagóri-

\footnotetext{
${ }^{8} \mathrm{O}$ ramo do conhecimento que se dedicava ao estudo das operações numéricas e ao uso dos números em situações práticas era conhecido, entre os gregos da Antiguidade, por logística.

${ }^{9}$ Jacob Golius (1596-1667) nasceu nos Reinos Germânicos. Foi para Leyden (1612) estudar matemática. Em 1618, registrou-se também no estudo de línguas arábicas. Após o retorno, em 1629, de uma viagem que realizou à Síria, tornou-se professor de matemática e de língua árabe, na universidade de Leyden. Foi Golius quem apresentou o problema da extensão a quatro retas do teorema de Pappus a Descartes, que o resolveria no apêndice Geometrie, do Discurso do Método (1637).
} 
cos para alicerçar suas argumentações sobre a natureza dos cometas, mas é o próprio Galileu quem expressa claramente ideais pitagóricos ao afirmar:

Talvez considere a filosofia como um livro de fantasia de um homem, como a Ilíada e Orlando Furioso, livros em que a coisa menos importante é a verdade daquilo que apresentam escrito. Sr. Sarsi, a coisa não é assim. A filosofia encontra-se escrita neste grande livro que continuamente se abre perante nossos olhos (isto é, o universo), que não se pode compreender antes de entender a língua e conhecer todos os caracteres com os quais está escrito. Ele está escrito em língua matemática ${ }^{10}$ (GALILEU, 1996, p. 46).

Foi também na Idade Moderna que novas religiões cristãs emergiram, a partir da Reforma Protestante. Nos meios burgueses protestantes, o acesso ao conhecimento e suas aplicações ao trabalho estavam relacionados a uma moral que objetivava a salvação, no Juízo Final. É nesse contexto que Amós Comenius (1592-1670) elaborou seu livro para alfabetização de crianças, o qual recorria a palavras do cotidiano infantil apresentadas por meio de desenhos. É no Desenho do Mundo - Orbis Pictus (1657) - que encontramos Pitágoras como exemplo de moral a ser seguida. No capítulo Filosofia Moral, Comenius afirma: "A vida tem um caminho, ou duas vias, como está subentendido na carta Y. de Pitágoras: 1 . sobre o lado esquerdo, um espaço estreito; 2. sobre o lado direito, [...]. Aquele pertence aos vícios, este à virtude" (COMENIUS, 1887, p. 136). Tal passagem de Comenius provavelmente é derivada do texto de Jâmblico ou de textos que se remetem a ele. Em seu livro, Vida Pitagórica, Jâmblico apresenta Pitágoras como uma pessoa que, devido a uma educação esmerada e também a seu modo de ser pretensamente divino, teria desenvolvido uma conduta moral norteada por piedade, disciplina, quietude e serenidade, por um modo de vida transcendentemente bom, por firmeza de espírito e por um corpo submisso à razão. Ainda segundo aquele autor, Pitágoras, em suas preleções, teria exortado os jovens a cultivar a aprendizagem de tais valores morais (JAMBLICO, 1818).

\footnotetext{
${ }^{10}$ Há que se ressaltar uma diferença básica entre o que afirma Galileu e as ideias pitagóricas, pois, para Galileu, a matemática se configura como uma linguagem que expressaria as verdades do universo, enquanto, para aqueles sábios gregos, o universo seria constituído por números, ou seja, pela junção de mônadas que seriam unidades.
} 
Nos primeiros séculos da Idade Moderna, a matemática ganhou proeminência, não apenas por suas aplicações práticas, mas principalmente porque tais aplicações possibilitavam à classe burguesa disseminar um discurso sobre a utilidade do conhecimento e sua importância para o trabalho e, por consequência, questionar o velho modo de vida contemplativa da nobreza e de setores da Igreja Católica. Tais setores ainda tinham por base os ensinamentos da escolástica aristotélica, cujo conteúdo de ensino reservava uma minúscula parte à matemática (cf. BRITO, 2012; BRITO, 2014). Assim, a matemática fez parte da rede de discursos de poder que buscavam fundamentar as práticas sociais burguesas. Essa rede foi inserida na educação escolar para participar da formação daqueles que dariam continuidade ao projeto social burguês.

A relação entre o ensino de matemática e a apologia ao conhecimento útil está presente, por exemplo, em textos de Joaquim Jungius ${ }^{11}$ (1587 - 1657). Quando se tornou reitor do Ginásio de Hamburgo, Reinos Germânicos, em 1629, esse pensador realizou um discurso, intitulado Sobre a Utilidade Propedêutica Da Matemática Para o Estudo da Filosofia - Über Den Propëdeutischen Nutzen Der Mathematik Für Das Studium Der Philosophie - em que defendia o ensino de matemática às crianças e adolescentes e se opunha a conceitos provindos dos ensinamentos da escolástica, conforme observamos no trecho a seguir:

Pois, a criança e o adolescente jovem não desprezam e descobrem os números e as figuras, as quais admiram, exploram e com as quais se deleitam [...], ao contrário dos adultos cujo intelecto está ocupado com a quinta essência do céu, com a matéria eterna sublunar, com o movimento inteligente das órbitas, com qualidades ocultas (JUNGIUS, 1629 , p. 103 , tradução nossa) $)^{12}$.

\footnotetext{
$\overline{{ }^{11} \text { Joaquim Jungius }}(1587$ - 1657) era luterano e nasceu em Lübeck, Reinos Germânicos. Formou-se matemático e médico em Rostock e obteve o título de doutor em Pádua. Com seu amigo Johann Adolf Tassius (1585 - 1654) fundou, em 1622, da Sociedade Ereunética, que tinha aproximações com o movimento Rosacruz.

${ }^{12}$ Puer itaque aut adolescentulus vilia haec non fastidiet, invenient in numeris, in figuris quod miretur, quo delectetur, quod rimetur, [...] contra adultioribus quorum intellectus iam quinta coeli essential, materia sublunarium aeterna, intelligentiis orbium motricibus, occultis qualitatibus (JUNGIUS, 1629, p. 103).
} 
Nessa retomada da importância da matemática para a educação, conceitos pitagóricos e neopitagóricos voltaram a ter proeminência, inclusive em livros textos utilizados em Ginásios Acadêmicos protestantes.

A necessidade de formar pessoas imbuídas dos ideais burgueses - e também dos protestantes - foi uma das razões da criação dos Ginásios Acadêmicos, Akademishe Gymnasium, nos Reinos Germânicos. O primeiro Ginásio Acadêmico era católico e foi fundado pelos jesuítas, em 1552, na região do Tirol. O primeiro Ginásio protestante foi criado em 1556 em Estrasburgo e, segundo Schubring (2002), era um novo tipo de instituição que tinha por intuito ensinar novos idiomas e o conhecimento filosófico de então aos alunos que já dominavam o latim. Em tais ginásios, o ensino estava dividido em classes, mas elas não eram as mesmas em todos eles. No Ginásio Acadêmico protestante luterano de Hamburgo, fundado em 1613, havia classes de grego, hebraico, lógica, filosofia natural, ética, física e matemáticas. Abordaremos, a seguir, conteúdos de alguns dos livros textos utilizados nesses ginásios.

Entre os séculos XVI e XVII, na Europa, houve um grande aumento de livros textos publicados com o intuito de serem utilizados na educação escolar. Podemos considerar que tal incremento, nesse período, foi possibilitado, entre outros fatores, pela maior rapidez na impressão dos livros, circulação maior de dinheiro, abertura de um mercado consumidor de mapas e livros impressos, além do pressuposto protestante de que todos, independente de serem homens ou mulheres, deveriam saber ler. É nesse contexto que foram impressos livros utilizados no Ginásio de Hamburgo, como, por exemplo, o Geometria Empírica.

$\mathrm{Na}$ abertura do posfácio de seu livro Geometria Empírica (1630), Jungius cita o neoplatônico Proclus (sec. V), segundo o qual, "aqueles que desprezam o conhecimento da disciplina matemática têm uma degustação mínima do prazer que ela proporciona" (JUNGIUS, 1630, p. 35) ${ }^{13}$. Em outro trecho, para certificar a utilidade dessa área de conhecimento, Jungius assevera:

[...] aqueles que comentam as disciplinas matemáticas para além da mesmice, falam de Erastótenes, dos martelos de Pitágoras, da pomba

\footnotetext{
${ }^{13}$ Traduzido de "Qui disciplinarum Mathematicarum cognitionem contemnunt, voluptares, quae in ipsis sunt, minime degustarunt”.
} 
voadora de Archytas, da determinação da quantidade de ouro na coroa de Hierão, as roldanas e a cochlea de Arquimedes, o Athos de Dinocratis, as esferas armilares e sextantes de Tycho e o louvável telescópio desenvolvido por Galileu (JUNGIUS, 1630, posfácio, tradução nossa) ${ }^{14}$.

Nessa passagem, Jungius faz referência aos estudos de Arquimedes e aos de Erastótenes, ao suposto experimento com martelos para o estudo da harmonia musical, de Pitágoras, à invenção de um suposto mecanismo voador em forma de pássaro, atribuído ao pitagórico Arquitas de Tarento (sec. V a.C.) e à cidade que teria sido construída sobre o monte Athos pelo pitagórico Dinocrates (sec. IV a.C.). Ou seja, Jungius invoca feitos supostamente atribuídos aos pitagóricos para comprovar a grandeza e utilidade da matemática e, ao fazer isso, divulga uma ideia de que estudos dos pitagóricos estariam voltados às questões práticas.

Antes de Jungius, Petrus Ramus ${ }^{15}$ (1515-1572) escreveu o livro I da obra Das Escolas Matemáticas - Scholarum Mathematicarum, livro texto bastante usado nos meios educacionais protestantes. Nessa obra, Ramus, a partir da leitura do livro do neoplatônico Proclus, afirmava que os pitagóricos Leo, Hermotimus, Arquitas, Eudoxo, além do próprio Pitágoras, teriam sido nobilíssimos inventores da matemática (cf. RAMUS, 1599). Segundo ele, a matemática seria uma arte de utilidade popular, “[...] a aritmética é tratada nos negócios, as dimensões da terra se conhece graças à geometria e tem seu lugar nobre na teologia pelo mérito de cultivar o profetizado" (RAMUS, 1599, p. 42) ${ }^{16}$. Apesar de se referir várias vezes, em sua obra, a Pitágoras e a outros pitagóricos, sua geometria e a aritmética não seguem aquela encontrada nos Elementos de Euclides, nem a obra do neopitagórico Nicômaco de Gerasa. Em vez disso, Ramus fornece ao leitor uma aborda-

\footnotetext{
${ }^{14}$ Qui Mathematicas disciplinas commendant, eorumalius mesolabium Eratosthenis, alius malleos Pythagorae, alius columbam volantem Archytae, coronam auream Hieronis, polyspasta et cochleas Archimedis, alius Dinocratis Athon, alius armillas et sextantes Tychonicos, aut telescopium Galilaei laudibus extollit (JUNGIUS, 1627, posfácio).

${ }^{15}$ Petrus Ramus é o nome latinizado do filósofo francês calvinista Pierre de la Ramée.

${ }^{16}$ Traduzido de "Arithmeticam tractandae mercaturae, Geometria dimetiendae terrae gratia, \& a nobis suo loco theologia illa pro merito suae divinitatis excoletur".
} 
gem prática dos conhecimentos matemáticos com algoritmos das operações aritméticas e discussões sobre a geometria como "arte de bem medir".

Diferentemente da aritmética de Ramus, na encontrada no livro Compêndio de Aritmética Empirica (1626) - Arithmeticae Empiricae Compendium, de Johann Adolf Tassius (1585 - 1654), professor de matemática do Ginásio Acadêmico de Hamburgo - apesar de as quatro operações aritméticas serem citadas, seus algoritmos não são abordados. O livro inclui em seus conteúdos definições similares às da obra de Nicômaco de Gerasa, iniciando-se pela definição de número. A definição de número no livro de Tassius assemelha-se àquela apresentada no livro de Nicômaco, como se pode constatar abaixo:

Número é a adição de outros números, ou a adição de mais de dois números entre si, visto que a partir da unidade os números são feitos, ou seja, todos constam de unidades (TASSIUS, 1683, p. 1, tradução nossa) ${ }^{17}$. Número é uma multitude limitada ou a combinação de unidades ou o fluxo da quantidade feita de unidades; e a primeira divisão do número é em pares e ímpares (NICÔMACO, 1926, p. 190, tradução nossa) ${ }^{18}$.

O segundo capítulo do livro do professor de matemática do Ginásio Acadêmico de Hamburgo inicia-se com a definição de números pares e ímpares que recorrem à noção de medida, pois Tassius afirma que números pares são aqueles que podem ser medidos de forma binária, e ímpares seriam os demais. Já Nicômaco define pares como aqueles que podem ser divididos em duas partes iguais, sem que sobrem unidades, e ímpares aqueles cuja divisão em duas partes faz restar uma unidade. Nicômaco ainda esclarece que essa concepção é a ordinária da doutrina pitagórica.

A seguir, as obras desses dois autores definem números parmente par, imparmente ímpar e imparmente par, no entanto, tais definições não

\footnotetext{
${ }^{17}$ Numerus numero addi, sive duo pluresve numeri inter si addi dicintur, cum ex ijis fit unus numerous, qui totidem constat unitatibus (TASSIUS, 1983, p. 1).

${ }^{18}$ Number is limited multitude or a combination of units or a ftow of quantity made up of units; and the and the first division of numbers is even and odd (NICÔMACO, 1926, p. 190).
} 
usam os mesmos termos. Por um lado, Tassius continua a recorrer à ideia de medida em tais definições, por exemplo, afirma que 24 é um número imparmente par, pois pode ser medido tanto por 4 e 8 , quanto por 3 . Nesse compêndio de aritmética são dados exemplos das séries de números parmente pares $(2,4,16,32$ etc.) e imparmente pares (6, 10, 14 etc.). Por outro lado, Nicômaco explica tais números pela multiplicação dos fatores que os resultam, por exemplo, a multiplicação de números, a partir da unidade, por razão 2, resulta em uma sequência de números parmente pares. Deve-se observar que, ao contrário dos escritos de Nicômaco de Gerasa e de textos da Idade Média, tais como os de Isidoro de Sevilha e Boécio (sec. V), as séries exemplificadas no livro de Tassius não se iniciam pelo 1 .

A seguir, apresentam-se, em forma de teoremas, as propriedades de tais números, mas, enquanto Tassius se atém à análise da adição, subtração e multiplicação entre esses diferentes tipos de números, a obra de Nicômaco realiza uma análise das sequências numéricas resultantes de tais números, indicando as relações entre elas. Ao fim dessas partes, ambos os textos definem números primos e números compostos. Deve-se observar que, a partir dessas definições, o neopitagórico utiliza o termo "medir" para se referir à divisão entre números. Nicômaco apresenta o crivo de Eratóstenes para a determinação de primos, enquanto Tassius propõe a elaboração do crivo em um problema, mas sem citar sua denominação.

Os textos seguem com definições muito próximas de número perfeito. Tal número é comparado com os superabundantes e com os deficientes, ou seja, aqueles cuja soma dos divisores próprios é maior que o número e aqueles em que essa soma resulta em um número menor, respectivamente. O Compêndio de Aritmética afirma que todos os números perfeitos são pares e os exemplifica com os oito números perfeitos conhecidos até então. Na época de Nicômaco, os números perfeitos conhecidos eram apenas 6; 28; 496 e 8128. Porém, no capítulo XVI do livro I, o neopitagórico nos apresenta uma forma de obter os demais números perfeitos. Conforme é exposto em capítulo anterior, tal método foi confirmado por Euler, no entanto, deve-se ressaltar que por meio dele só são obtidos os números perfeitos pares.

Outro conceito abordado em ambos os livros é o de divisor comum, denominado por Nicômaco de medida comum. Ambos os autores inserem 
essa discussão naquela sobre dois números serem ou não primos entre si. Tassius afirma que divisor comum ou medida comum é aquela que é comum a dois números, sendo o máximo divisor comum o maior número entre todos os divisores comuns. O método das subtrações sucessivas é apresentado ao leitor como um teorema sobre o tema, sem exemplos numéricos. Nicômaco expõe tal método e o exemplifica pela determinação entre o divisor comum entre 23 e 45: subtraindo 23 de 45, resta 22. Então, se subtrai 22 de 23 e a diferença é 1 , portanto, eles são primos entre si. Outro exemplo usado pelo neopitagórico é a determinação do divisor comum entre 21 e 49: deve-se subtrair 21 de 49, o resto é 28. Em seguida, se subtrai novamente 21 de 28 , o resto é 7 . Então, se subtrai 7 de 21, quantas vezes for possível e o resto é zero. Portanto, 7 é o maior divisor comum entre os números e eles não são primos entre si.

$\mathrm{Na}$ obra de Euclides, a discussão sobre a existência ou não de uma medida comum a outras duas está relacionada ao conceito de comensurabilidade entre segmentos, pois, se tal medida comum existe, os segmentos serão comensuráveis, inclusive se os números que expressam as medidas forem primos entre si. Em caso contrário, eles são incomensuráveis, como, por exemplo, a medida do lado e a da diagonal de um quadrado. No entanto, nem Tassius nem Nicômaco abordam a questão da comensurabilidade em seus textos.

Após essas partes, os dois livros diferem, pois, enquanto o elaborado na Antiguidade Tardia envereda por uma discussão sobre múltiplos e submúltiplos, o da Idade Moderna segue analisando razões e proporções.

Portanto, concluímos que a matemática pitagórica se fez presente, em livros didáticos, tanto pela exaltação de sua importância para aplicações práticas, quanto por conceitos e modos de apresentação de tais conceitos desenvolvidos por aqueles filósofos.

Assim, percebemos que a necessidade de se formar pessoas dentro da ideologia burguesa ocasionou uma mobilização, em textos para o ensino da matemática do século XVII, de referências a Pitágoras e aos pitagóricos. Tais referências buscavam atestar, segundo a autoridade daqueles filósofos gregos, a importância da utilidade prática desse ramo do saber, o que ia ao 
encontro do discurso da superioridade do trabalho em relação à vida contemplativa. É Comenius, em sua Didática Magna (1657), quem nos diz que nas escolas não se deveria tratar

[...] senão daquelas coisas que são solidamente úteis para a vida presente e para a vida futura; mais ainda para a vida futura. (Nesta terra, com efeito, devem aprender-se, segundo o aviso de S. Jerônimo, precisamente aquelas coisas cujo conhecimento continuará no céu) (COMENIUS, 2006, p. 251).

Nesse contexto, se formou uma noção de Pitágoras e dos pitagóricos não apenas como filósofos gregos, mas como autoridades a serem seguidas tanto no que tange à produção de uma matemática prática que desvendava o universo, quanto como referência moral.

Desde então, o ensino de matemática tem participado da educação formal de crianças e adolescentes. Afirma-se que o ensino dessa disciplina objetiva não apenas fornecer um instrumental teórico útil à vida diária das pessoas, mas também formar maneiras de raciocinar - o que nós professores chamamos de "pensar matematicamente". Currículos e materiais didáticos reafirmam a utilidade dessa área do conhecimento sem, no entanto, revelar que a relação matemática-utilidade é histórica. A atual importância que se dá à matemática nas avaliações internacionais não surgiu do acaso; ela se insere em uma história do papel que a matemática tem desempenhado no desenvolvimento do capitalismo, história essa que passa pelo ensino dessa área nos ginásios acadêmicos do século XVII.

Entendemos que a reflexão sobre os caminhos pelos quais a matemática se tornou um objeto de ensino escolar e a análise dos elos históricos que ela manteve, e ainda mantém, com outros discursos de poder podem colaborar para que professores reavaliem algumas crenças sobre ela - como, por exemplo, que saber matemática é vocação ou que aqueles que aprendem matemática são mais inteligentes que os outros - e a tornem realmente útil na vida de seus alunos, para que tenham uma atuação cidadã na sociedade. 


\section{Referências}

ADAM, C.; TANNERY, P. Oeuvres de Descartes: Correspondance. Vol 1. Paris: Librairie Philosophique J. Vrin. 1969.

BRITO, A. J. O ensino de matemática no século XVII: entre a religião e as disputas político-econômicas. Revista Zetetiké, Campinas, v. 20, n.38, p.11-35, jul./dez. 2012,.

BRITO, A. J. Livros texto do século XVII: o que nos contam sobre o ensino atual de matemática? História da Ciência e Ensino. São Paulo, v.9, p.36-56, 2014.

COMENIUS A. Didática Magna. 5. ed. Lisboa: Fundação Calouste Gulbekian, 2006.

COMENIUS, A. Orbis Pictus. Syracuse; NY: C. W. Bardeen Publisher, 1887.

CORNELLI, G. O Pitagorismo como categoria historiográfica. Coimbra, Portugal: Centro de Estudos Clássicos e Humanísticos da Universidade de Coimbra, 2011.

GALILEI, G. O Ensaiador. S. Paulo: Editora Nova Cultural, 1996. (Coleção Os pensadores)

JAMBLICO. Life of Pythagoras or pytagoric life. Translated from Greek by Thomas Taylor. London: J. M. Watkins, 1818.

JAPIASSÚ, H.; MARCONDES, D. Dicionário básico de filosofia. Rio de Janeiro: Ed. Zahar, 1996.

JUNGIUS, J. Geometria Empírica. Rostock?, 1630, 95p.

JUNGIUS, J. “Über Den Propädeutischen Nutzen Der Mathematik Für Das Studium Der Philosophie: Rede, gehalten am 19 März 1629 beim Antritt des Rektorates in Hamburg”. Edição Bilíngue latim/alemão. In MEYER, A. (ed) Festschrift der Hamburgischen Universität: Beiträge zur Jungius-Forschung. Hamburg: Paul Hartung Verlag, 1929.

NICÔMACO. Introduction to Arithmetic. Translated into English by Martin L. D'Ooge. NY: Macmillam Company, 1926.

RAMUS, P. Scholarum mathematicarum libri unus et triginta. Francofurti: Claudium Marnium \& Joannem Aubrium, 1599.

SCHUBRING, G. A Framework for comparing transmission process of Mathematics to the Americas. Revista Brasileira de História da Matemática. v.2, n. 3, p. 45-63, 2002.

TASSIUS, A. Arithmeticae empiricae compendium. Zacharie Hertelli: Hamburg, 1683. 


\section{SOBRE MÉDIAS PITAGÓRICAS E MÉDIAS NOS LIVROS ESCOLARES DE MATEMÁTICA DO BRASIL (1900-1970)}

Sérgio Candido de Gouveia Neto

"Somos todos Pitagóricos"

(RIZEK, 2000)

\section{Introdução}

No prefácio do livro Pitágoras e o tema do número, de Mário Ferreira dos Santos (SANTOS, 2000), o professor Ricardo Rizek divide a paternidade do pensamento ocidental entre Parmênides, Platão e Pitágoras; ao último, é atribuído o papel de pai de toda nossa arte, principalmente a musical, pois Pitágoras teria contribuído para a teoria musical. Para Santos (2000), é mais do que isso, já que a "ciência moderna é mais pitagórica do que foi em qualquer tempo" (p. 71). Contudo, é importante notar que a ciência moderna separa o número das coisas, diferentemente dos pitagóricos, que consideravam o número como parte das coisas.

Santos (2000) também chama a atenção para a questão de que o pitagorismo passou por diversos estágios e recebeu contribuições das mais diversas origens. De uma maneira geral, isso corrobora a observação do filósofo alemão Eduard Zeller (cf. CORNELLI, 2011) de que, com o passar do tempo, as fontes sobre o pitagorismo aumentam em vez de diminuir, já que há muitas interpretações e elas acabam tornando-se fontes também. Assim, de acordo com Cornelli (2011), Zeller pôde concluir que a doutrina pitagórica, conhecida atualmente, é mais neopitagórica do que aquela recebida pelos testemunhos antigos. Se entendermos o pitagorismo como uma categoria construída historicamente, como mostra Cornelli (2011), podemos compreender o porquê de ele estar tão presente na nossa cultura, uma 
vez que está a todo momento sendo construído e reconstruído, servindo a diversas finalidades.

Conforme vimos nos capítulos anteriores, o pitagorismo espalhou suas raízes na música, na arquitetura, nas ciências e no meio escolar. De acordo com Brito - capítulo anterior -, a Matemática ganhou proeminência a partir do advento da burguesia no século XVII, principalmente quando os burgueses buscaram nessa ciência um discurso que justificasse suas aplicações. Essa retomada foi carregada de conceitos pitagóricos e neopitagóricos, principalmente nos livros de textos escolares dos séculos XVI e XVII.

Assim, pretendemos estender esta análise para os livros escolares de matemática do Brasil, nos primeiros setenta anos do século $\mathrm{XX}^{1}$, e realizar uma discussão sobre as definições e o conceito pitagórico das médias (aritmética, geométrica e harmônica) ao longo dos anos. Para tal, consultamos os livros destinados ao ensino escolar brasileiro do século XX (aritmética e geometria), que fazem parte do acervo dos repositórios do Grupo de Pesquisa História e Educação Matemática (Hedumat) da Universidade Federal Fluminense, coordenado pelo professor Bruno Alves Dassie, e o do Grupo de Pesquisa em História da Educação Matemática (Ghemat), coordenado pelo professor Wagner Rodrigues Valente.

Dentre os diversos temas pitagóricos e neopitagóricos, conforme já demostrado nos demais capítulos, a escolha pelas médias surgiu das discussões realizadas no grupo de estudo sobre o pitagorismo. Numa das apresentações que realizamos, discutimos como termos Pitagóricos apareciam e desapareciam dos livros de Matemática destinados ao ensino escolar, tais como a Tábua de Pitágoras, os números figurados, a ideia de máximo divisor comum, mínimo múltiplo comum, números primos, amigáveis etc. $\mathrm{Na}$ apresentação, chamou-nos a atenção o caso das médias, principalmente pelas mudanças das definições e posições do tema dentro do currículo, como assunto de aritmética no início do século XX e, atualmente, como

\footnotetext{
${ }^{1} \mathrm{~A}$ opção por esse recorte temporal é em função do banco de dados de livros consultado por nós, os quais disponibilizam, em sua maioria, livros publicados desde o século XIX até a década de 1970, do século XX.
} 
um tópico de estatística. Nesse sentido, questionamos como a noção de média mudou ao longo do tempo e, principalmente, dentro do currículo de Matemática escolar brasileiro.

Assim, o presente capítulo tem como objetivo fazer uma análise do conceito de médias, inicialmente em um texto Pitagórico antigo, como o de Nicômaco, o qual estabelece as médias por meio dos conceitos de proporções. Posteriormente, estenderemos as diversas mudanças das definições de médias, contidas nos livros de Matemática Escolar do Brasil, nos primeiros setenta anos do século XX.

\section{Das proporções em Nicômaco aos diversos conceitos de médias nos livros de Matemática Escolar do Brasil}

No capítulo XXII, livro II, do seu Introduction to Arithmetic, Nicômaco de Gerasa assim se pronuncia sobre os casos especiais de proporções:

As primeiras três proporções, que são reconhecidas por todos os antigos, Pitágoras, Platão e Aristóteles, são as aritméticas, geométricas e harmônicas; e há outras três subcontrárias a elas, que não têm nomes próprios, mas são chamadas, em termos mais gerais, de quarta, quinta e sexta formas. Depois disso, os modernos também descobriram quatro outras, constituindo o número dez, o que, de acordo com a visão de Pitágoras, é o mais perfeito possível. De acordo com esse número, de fato, não há muito tempo, as dez relações foram observadas para tomar seu número apropriado, as chamadas dez categorias, as divisões e formas das extremidades de nossas mãos e pés, e inúmeras outras coisas que devemos pôr no lugar apropriado (NICÔMACO, 1926, p. 266, tradução nossa) $)^{2}$.

\footnotetext{
${ }^{2}$ Te first three proportion, then, which are acknowledge by all ancients, Pitágoras, Plato, and Aristósteles, are the arithmetic, geometric, and harmonic; and there are three others subcontrary to hem, which do not have names of their own, but are called in more general terms the fourth, fifth, and sixth forms of mean. After which the moderns discover four others as well, making up the number ten, hich, according to the Pitágoras view, is the most perfect possible. It was in accordance with this number indeed that not long ago the ten relations were observed to take their proper number, the so-called ten categories, the divisons and forms of the extremities of our hands and feet, and countless other things which we shall notice in the proper place. (NICÔMACO, 1926, p. 266).
} 
Para Nicômaco, as proporções eram dez, sendo que as três principais seriam a aritmética, a geométrica e a harmônica. Ele analisa a relação entre essas proporções e o comportamento delas em relação aos seus termos:

[...] uma coisa que todos os escritores anteriores também observaram, as razões entre os termos menores são maiores, em comparação com aqueles entre os termos maiores. Será mostrado que, na proporção harmônica, pelo contrário, as proporções entre os termos maiores são maiores que entre os menores ${ }^{3}$, por isso a proporção harmônica é subcontrária à aritmética, e a geométrica está no meio delas, por assim dizer, entre os extremos, essa proporção tem os índices entre os termos mais amplos e aqueles entre o menor igual, e vimos que o igual está no meio entre o maior e o menor. [...] (NICÔMACO, 1926, p. 269, tradução nossa $)^{4}$.

Em nossa análise dos livros de matemática destinados ao ensino nas escolas brasileiras, encontramos uma discussão semelhante sobre as médias aritméticas e geométricas na obra Noções de Arithmetica - para uso das escolas primárias, de F. Marcondes Pereira ${ }^{5}$, publicado em 1905, pela Editora Aillaud e Cia, Paris:

[...] Média differencial ou meio arithmetico - é o meio de uma equidifferença contínua. Diz-se que uma equidifferença é contínua, quando os seus meios ou os seus extremos são eguaes; assim: $8-x=x-4$. O

\footnotetext{
${ }^{3} \mathrm{O}$ tradutor da obra de Nicômaco mostra um exemplo: Na série 1, 2, 3, comparando a razão dos termos menores $(1,2)$ com os termos maiores $(2,3)-2: 1>3: 2$. Em comparação com os termos de uma progressão harmônica 3,4,6 temos 4:3 < 6:4. A proporção geométrica ocupa o meio entre a proporção aritmética e harmônica. Assim, dado 1,2,4 - 2:1=4:2

${ }^{4}[\ldots]$ a thing which all previous writers also have noted, the rations between the smaller terms are larger, as compared to those between the greater terms. It will be shown that in the harmonic proportion, on the contrary, the ratios between the greater terms are greater than those between the smaller, for this reason the harmonic proportion is subcontrary to the arithmetic, and the geometric is midway them, as it were, between extremes, for this proportion has the ratios between the greather terms and those beween the smaller equal, and we have seen that the equal is in the middle ground between the great and the less. (NICÔMACO, 1926, p. 269).
}

${ }^{5}$ Sobre o professor F. Marcondes Pereira, sabemos que ele era engenheiro civil e 'Lente' de Aritmética e Álgebra do Liceu do Ceará. 
valor do meio ou média diferencial é: $8+4=2 \mathrm{x}$ ou $2 \mathrm{x}=12$, donde $\mathrm{x}=$ $12 / 2=6$. Logo, a média Arithmetica entre duas quantidades - é igual à semi-somma (metade da somma) dos extremos. Ou, se é extremo, como na equidifferença: $\mathrm{x}-2=8-\mathrm{x}$, temos: $2 \mathrm{x}=10$, donde $\mathrm{x}=5$, o valor de $\mathrm{x}$ é então a semi-soma dos meios (PEREIRA, 1905, p. 121).

Pereira (1905), continuando as discussões sobre as proporções, define assim a média geométrica:

[...] Média proporcional ou meio geométrico - é o meio - desconhecido - de uma proporção contínua, isto é, que tem os dois meios ou os dois extremos eguaes. Exemplo: a proposição 18:x::x:2 é contínua e x é a média proporcional entre os extremos 18 e 2 . Determina-se o seu valor pela propriedade fundamental: $18.2=x . x$ ou $36=x^{2}$, donde $x$ $=\sqrt{36}=6$. Logo, a média proporcional entre duas quantidades (18 e 2) é egual à raiz quadrada do produto dessas quantidades (PEREIRA, 1905, p. 122).

Novamente, em outro livro publicado quase na mesma época, em 1910, pela Typografia do Jornal do Commercio, a Arithmetica Elementar, de Antonio Monteiro de Souza ${ }^{6}$, apresenta uma definição muito próxima para as médias aritméticas e geométricas:

[...] Em toda a equidifferença contínua ${ }^{7}$ o meio differencial é igual à metade da somma dos extremos (média aritmética) [...] (SOUZA, 1910, p. 152).

..

[...] Em toda a proporção contínua o meio proporcional é igual à raiz quadrada do produto dos extremos [...] (média geométrica) (SOUZA, 1910, p. 152).

\footnotetext{
${ }^{6}$ Antonio Monteiro de Souza foi diretor e lente de Matemática Elementar do Ginásio Amazonense e cursos anexos, no Estado do Amazonas.

${ }^{7}$ Para Souza (1910), “equidifença contínua é aquella em que os meios são iguais" (p. 150).
} 
Além de as médias proporcionais aparecerem em assuntos de aritmética, elas estavam presentes como tópicos dos livros de geometria, e é o caso, por exemplo, do ponto contido no livro Curso Completo de Matemática Elementar, de Liberato Bittencourt, publicado em 1922, pelas Oficinas Gráficas do Ginásio de Santos. Em seu livro, há dois pontos em que ele trata das médias proporcionais. No capítulo denominado Teoria da Semelhança, há o seguinte teorema:

Teorema: a perpendicular ao diâmetro, por um ponto qualquer da circunferência, é média proporcional entre os segmentos que ela determina sobre o diâmetro.

Seja $\mathrm{AD}$ perpendicular ao diâmetro $\mathrm{BC}$. Tracemos $\mathrm{AB}$ e $\mathrm{AC}$ : o triângulo $\mathrm{BAC}$ será rectângulo em $\mathrm{A}$, sendo $\mathrm{AD}$ a respectiva altura. Ter-se-á, portanto:

$\frac{m}{d}=\frac{d}{n}$ ou $d^{2}=$ m.n (BITTENCOURT, p. 111, 1922).

Esse Teorema foi usado posteriormente para abordar o seguinte problema:

\section{Problema: achar a média proporcional entre duas rectas dadas.}

Sejam $m$ e $n$ as rectas dadas. Sobre a recta AX, tomem-se as distâncias $\mathrm{BD}=\mathrm{m}$ e $\mathrm{DC}=\mathrm{n}$ e sobre $\mathrm{BC}$, como diâmetro, construa uma circunferência: a perpendicular ao diâmetro, $\mathrm{AD}$, será a média proporcional pedida. Porque a perpendicular ao diâmetro é média proporcional entre os segmentos por ele determinados. (BITTENCOURT, p. 115, 1922, grifo do autor).

Nos dois pontos, ele utilizou a imagem de um triângulo inscrito numa circunferência para tratar a questão da média proporcional (Figura 1). 
Figura 1 - Imagem do livro Curso Completo de Matemática Elementar, de Liberato Bittencourt, para tratar sobre as médias proporcionais

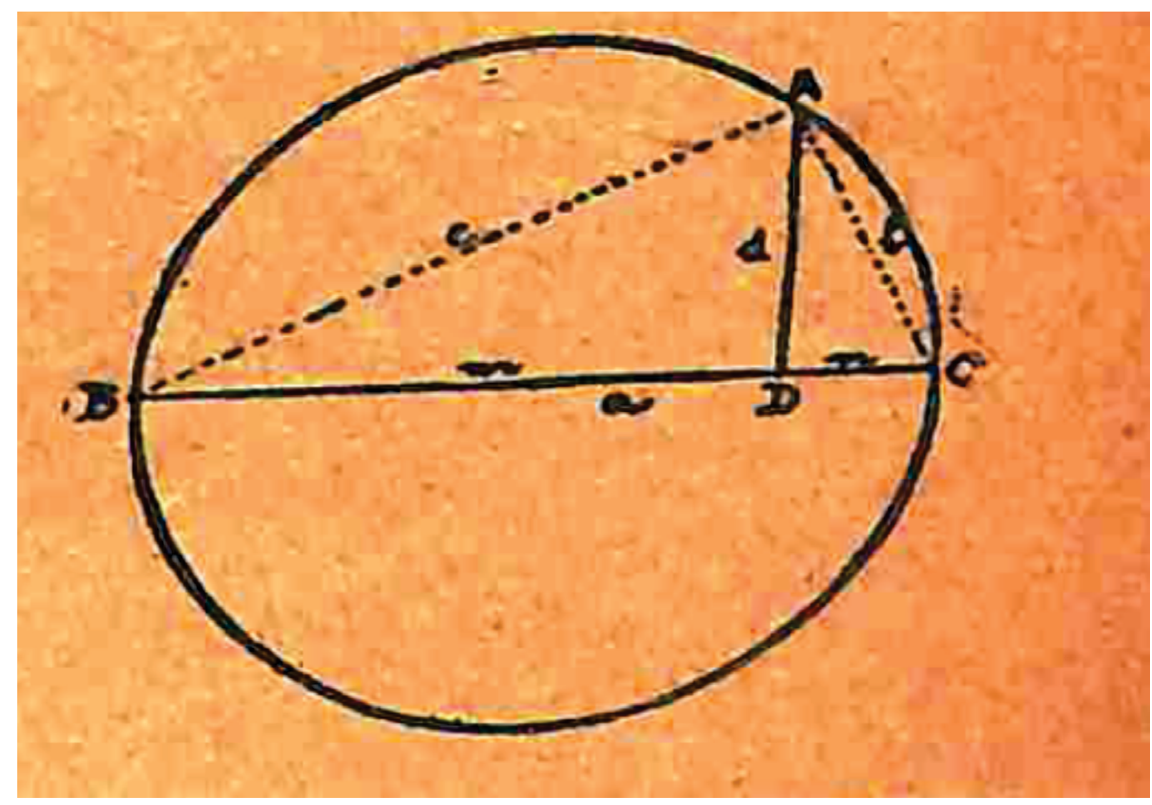

Fonte: Bittencourt (1922)

A proporção harmônica foi abordada nesses livros como parte integrante da geometria. Isso aparece, por exemplo, na terceira edição do livro Elementos de Geometria, de André Perez y Marin e Carlos Francisco de Paula, publicado em 1912, pela Companhia Editora Melhoramentos. No item 123, a proporção harmônica é assim definida:

Proporção harmônica - Quando dois pontos, taes como M e M', dividem o segmento $A B$ de tal modo que os segmentos additivos são proporcionaes aos subtractivos, diz-se que elles dividem harmonicamente o segmento $A B$, ou que são conjugados harmônicos em relação a AB. [...] chama-se proporção harmônica e escreve-se commumente da seguinte forma:

$\frac{M A}{M B}: \frac{M^{\prime} A}{M \prime B}=-1$ (PEREZ y MARIN; PAULA, p. 66, 1912). 
Nota-se, assim, que essas definições de médias proporcionais e proporção harmônica são muito diferentes daquelas presentes no texto de Nicômaco. Contudo, percebe-se uma ausência de discussões ou de aplicações para a proporção harmônica ${ }^{8}$ do ponto de vista aritmético, já que há semelhanças entre as definições de médias - aritméticas e geométricas - contidas nesses livros e as acepções presentes no texto de Nicômaco.

Outra questão a ser observada é que as discussões sobre as médias aritméticas e geométricas aparecem nos capítulos que tratam das razões e proporções ou em tópicos que antecedem os assuntos de regra de três e regra de juros simples, como na Arithmetica Elementar, por exemplo, de Antônio Monteiro de Souza (SOUZA, 1910).

Apesar disso, esses livros que analisamos apresentam outra definição para média aritmética, que se tornará mais presente em publicações posteriores de outros autores. Souza (1910), por exemplo, define a regra do termo médio:

[...] O termo médio entre dois números é o quociente da somma desses dois números dividida por 2 , entre três, o quociente da somma dos três divididos por 3; entre quatro, o quociente da somma dos quatro dividida por 4 e assim por diante. Portanto:

Regra: para achar o termo médio entre dois números ou mais números divide-se a sua somma pelo número deles (SOUZA, 1910, p. 170, destaque do autor).

Semelhante ao caso das médias aritméticas e geométricas, essa definição de termos médios aparece como aplicações em assuntos de matemática comercial e financeira, como no seguinte problema para resolver, proposto no livro: “[...] Uma pessoa comprou $8 \mathrm{~kg}$ de farinha a 800 réis, 5 a 400 réis e $12 \mathrm{k}$ a 300 réis; qual o preço médio de 1 kilograma?” (SOUZA, 1910, p. 171).

\footnotetext{
${ }^{8}$ Dados três números $a, b$ e $c$, a média harmônica é o número de membros dividido pelas somas dos inversos dos números $a, b$ e $c$, ou seja, $\mathrm{MH}=\frac{3}{\frac{1}{a}+\frac{1}{b}+\text {; }}$
} 
Em outros livros de anos posteriores, essa definição de termo médio apareceu junto à média proporcional (geométrica). O livro de Zanello, Aritmética primária, publicado em 1941, pela Companhia Editora Nacional, representa tal questão:

Médias - média aritmética ou simplesmente média de dois ou mais números é o quociente da divisão da soma desses números pelo seu número. Assim, a média aritmética dos números 6; 8; 0,4 e 2,6 é: $\frac{6+8+0,4+2,6}{4}=\frac{17}{4}=4,25$

Denomina-se proporção contínua aquela cujos meios são iguais. Ao meio de uma proporção contínua chama-se média proporcional ou média geométrica entre os dois extremos. Assim, para a proporção $\frac{4}{6}=\frac{6}{9}$ é contínua e 6 é a média proporcional ou média geométrica entre os extremos 4 e 9. (ZANELLO, 1941, p. 195, destaque do autor).

Entretanto, mesmo havendo uma mistura de definições, elas continuam como aplicações de assuntos de matemática comercial e financeira. Já não é o caso de livros publicados na década de 1950, analisados neste ensaio, nos quais o conceito de média aritmética passou a ser uma aplicação da estatística, como uma medida de posição. O livro Matemática e Estatística - para os Institutos de Educação e Escolas Normais, de Osvaldo Sangiorgi (1956, p. 227), é um exemplo disso:

Médias aritméticas simples. Chama-se média aritmética de uma série de valores ao quociente da divisão da soma desses valores pelo seu número. Indicando os diversos valores ( $\mathrm{n}$ ) que uma variável $\mathrm{x}$ da série pode assumir por: $\mathrm{x}_{1}, \mathrm{x}_{2}, \mathrm{x}_{3}, \ldots, \mathrm{x}_{\mathrm{n}} \mathrm{e}$, por $\mathrm{M}_{\mathrm{a}}$ a média aritmética, temos: $M a=\frac{x 1+x 2+x 3 \ldots+x n}{n}$ (SANGIORGI, 1956, p. 227).

Consultamos outros livros de Sangiorgi e não encontramos nenhuma definição de média, principalmente aquelas relacionadas ao Movimento da Matemática Moderna (MMM). Além dos livros de Sangiorgi, disponibilizados no banco de dados on-line de livros do Ghemat, examinamos obras de autores que, de alguma forma, estavam relacionados ao MMM. Assim, 
por exemplo, textos que continham o termo "matemática moderna", ou mesmo de autores conhecidos como participantes do MMM, caso de Lucília Bechara; Manhúcia Limberman e Anna Franchi. Em nenhum deles continha o assunto de 'médias'.

Contudo, fica a questão: como foi trabalhado o assunto sobre as médias (aritmética, geométrica e harmônica) nas escolas brasileiras durante as décadas de setenta e oitenta do século XX, se as principais referências bibliográficas não abordaram o tema? No entanto, é possível que tais tópicos tenham sido apropriados ou delegados ao desenho geométrico, muito embora não tenhamos analisado os livros de desenho geométrico daquele período.

Mais recentemente, a média aritmética passou a constar como assunto nos Parâmetros Curriculares Nacionais de Matemática de primeira à quarta série (BRASIL, 1997), isto é, na parte relativa ao tema transversal meio ambiente e na parte relativa ao tratamento da informação (estatística), em que o objetivo é "obtenção e interpretação de média aritmética" (BRASIL, 1997, p. 59). Assim:

A compreensão dos fenômenos que ocorrem no ambiente - poluição, desmatamento, limites para uso dos recursos naturais, desperdício - terá ferramentas essenciais em conceitos (médias, áreas, volumes, proporcionalidade, etc.) e procedimentos matemáticos (formulação de hipóteses, realização de cálculos, coleta, organização e interpretação de dados estatísticos, prática da argumentação, etc.). (BRASIL, 1997, p. 27).

$\mathrm{Na}$ Base Nacional Comum Curricular (BNCC) do Ensino Médio, documento mais recente, o tópico sobre média está na parte de probabilidade e estatística, na Unidade Curricular I: "Utilizar a média, a mediana e a amplitude para descrever, comparar e interpretar dois conjuntos de dados numéricos obtidos nas pesquisas realizadas pelos estudantes, em termos de localização (centro) e dispersão" (BRASIL, 2016, p. 570).

Entretanto, isso não significa que o tema das médias (aritmética, geométrica e harmônica) tenha sido abandonado. As médias ainda estão presentes nos livros didáticos de Matemática, principalmente a média arit- 
mética, com aplicações, sobretudo, no campo do tratamento da informação (ANJOS; GITIRANA, 2008), mas isso é outra história...

Ressaltamos que este estudo tratou de um olhar macro sobre o tema das médias, contidos nos livros destinados ao sistema escolar brasileiro, ao longo de quase 70 anos, o que constitui uma limitação do trabalho. Dessa forma, estudos mais detalhados fazem--se necessários para analisar como a questão das médias foi tratada, por exemplo, em modalidades de ensino (ginasial, comercial, industrial etc.).

Dessa forma, será possível traçar cenários de mudanças sobre o ensino das médias em diversas modalidades de ensino. As discussões realizadas neste texto dão uma amostra da potência de estudos nesse sentido: das médias proporcionais (aritmética, geométrica e harmônica) em Nicômaco, notou-se uma modificação, para servir a outras finalidades como a estatística. As médias proporcionais (aritmética e geométrica) estão presentes nos livros de Matemática escolar brasileira, mas de maneira bem diferente do formato tratado por Nicômaco.

Assim, é interessante ressaltar a ausência da média harmônica nos livros de Matemática destinados ao sistema escolar, do ponto de vista aritmético. $\mathrm{O}$ exemplo que apresentamos mostra uma definição sobre proporção harmônica, como parte da geometria. Por que a matemática escolar do Brasil não trabalhou a média harmônica do ponto de vista da aritmética? Por que a opção pelas médias aritméticas e geométricas apenas? Não conseguimos responder essas questões aqui, mas as deixamos como oportunidade de pesquisa para outros trabalhos.

De uma forma geral, ao que parece, há sempre um retorno aos temas pitagóricos no ensino ou mesmo na cultura como um todo, o que explica, em parte, o destaque dos conceitos, principalmente aqueles relacionados à ideia de que tudo é número e de que tudo, ou quase tudo, pode ser explicado pela Matemática. Em 2017, percebemos isso claramente no tema da Semana Nacional de Ciência e Tecnologia de 2017: "A Matemática está em Tudo". Assim, a temática coaduna-se com a concepção de Santos (2000), de que ciência moderna é mais pitagórica do que o foi em qualquer tempo. 


\section{Referências}

ANJOS, D.; GITIRANA, V. Exploração do conceito de média em livros didáticos das séries finais do ensino fundamental. In: II - SIPEMAT - Simpósio Internacional de Pesquisa em Educação Matemática, 2008, Recife. Anais do II SIPEMAT - Matemática formal e Matemática não-formal, 20 anos depois: sala de aula e outros contextos, 2008.

BRASIL. Ministério da Educação. Secretaria de Educação Fundamental. Parâmetros Curriculares Nacionais: Matemática. Brasília: MEC, 1997. 142p.

BRASIL. Ministério da Educação. Base Nacional Comum Curricular (BNCC). Brasília: MEC, 2016.652p.

BITTENCOURT, L. Curso completo de Matemática Elementar - Geometria. Santos: oficinas gráficas do Ginásio, 1922.

CORNELLI, G. O Pitagorismo como categoria historiográfica. Coimbra, Portugal: Centro de Estudos Clássicos e Humanísticos da Universidade de Coimbra, 2011.

NICÔMACO. Introduction to Arithmetic. Translated into English by Martin L. D'Ooge. NY: Macmillam Company, 1926.

PEREIRA, F. M. Noções de Arithmetica para uso das escolas primárias - Estudo prático e Indutivo. 2.ed. Fortaleza: Editor Militão Bivar. Paris:Typografia Aillaud e Cia, 1905.

PEREZ Y MARIN, A.; PAULA, C.F. Elementos de Geometria. 2.ed. Companhia Editora Melhoramentos de São Paulo, 1912.

RIZEK, R. Prefácio. In: SANTOS, M. F. Pitágoras e o tema do número. São Paulo: IBRASA, 2000.

SANGIORGI, O. Matemática e Estatística - Para os Institutos de Educação e Escolas Normais. São Paulo: Companhia Editora Nacional, 1956. 252p.

SOUZA, A. M. Arithmetica Elementar. 4.ed. Rio de Janeiro: Typografia do "Jornal do Commercio", 1910. 182 p.

ZANELLO,H. Aritmética Primária. 3.ed. São Paulo: Companhia Editora Nacional, 1941. 
[...] A "questão pitagórica" pode sem dúvida ser equiparada à "questão homérica", a saber, um conjunto de indagações a respeito da vida e da obra desses personagens. Afinal, quem foi Pitágoras? Ele de fato existiu? Se sim, quais fatos tornaram a sua vida memorável? Teria ele sido um místico? Um cientista? Filósofo? Líder político? Charlatão? Talvez um pouco de cada uma dessas coisas, sem que possa ser definido de modo definitivo por uma única. Quais são os elementos fundamentais de sua doutrina? E como eles prevalecem na tradição posterior, com uma roupagem adequada aos seus próprios tempos?

[...] O livro ... cobre aspectos artísticos e didáticos, científicos e filosóficos, tendo sua utilidade assegurada tanto ao interessado em cultura geral e no pitagorismo, como ao educador que aqui encontrará direcionamentos para lidar com Pitágoras e os pitagóricos com muito mais propriedade em suas aulas.

Prof. Dr. Gustavo Barbosa 



\section{SOBRE OS AUTORES}

\section{Carla Patrícia Ferreira dos Santos}

Mestranda em Matemática no Programa de Pós-Graduação em Matemática do Instituto de Geociências e Ciências Exatas da Universidade Estadual Paulista "Júlio de Mesquita Filho" (Unesp), Campus Rio Claro; Professora do Estado de São Paulo. Licenciada em Matemática pela FAAL - Faculdade de Administração e Artes de Limeira.

\section{Islenis Carolina Botello Cuvides}

Doutoranda em Educação Matemática pelo Programa de Pós-Graduação em Educação Matemática da Universidade Estadual Paulista "Júlio de Mesquita Filho" (Unesp), Rio Claro - SP. Mestre em Educação Matemática (2013) e Licenciada em Matemática pela Universidade Industrial de Santander (UIS), Colômbia (2011). Tem experiência na área de Educação Matemática, atuando principalmente nos seguintes temas: Matemática, História, Formação Docente e Professores de Matemática.

\section{Renata Caterine Gambaro Cleto da Silva}

Mestranda em Educação Matemática no Programa de Pós-Graduação em Educação Matemática do Instituto de Geociências e Ciências Exatas da Universidade Estadual Paulista "Júlio de Mesquita Filho" (Unesp), Campus Rio Claro. Durante a Graduação em Licenciatura em Matemática na Unesp, Campus Rio Claro, foi bolsista BAAE-I; foi bolsista no Programa Institucional de Bolsas de Iniciação à Docência (Pibid); e foi bolsista Núcleo de Ensino, no qual trabalhou com formação de professores de Matemática.

\section{Jean Sebastian Toillier}

Docente da Universidade Estadual do Oeste do Paraná (Unioeste), campus Cascavel, vinculado ao Centro de Ciências Exatas e Tecnológicas (CCET) e do Colegiado de Matemática. Doutorando em Educação Matemática no Programa de Pós-Graduação em Educação Matemática (Ppgem) da 
Universidade Estadual Paulista "Júlio de Mesquita Filho"(Unesp), Campus de Rio Claro. Mestre em Educação Matemática pelo Ppgem da Unesp, Campus de Rio Claro.

\section{Débora Vieira de Souza}

Doutoranda em Educação Matemática no Programa de Pós-Graduação em Educação Matemática do Instituto de Geociências e Ciências Exatas da Universidade Estadual Paulista "Júlio de Mesquita Filho" (Unesp), Campus Rio Claro. Mestre em Ensino de Ciências e Matemática pelo Instituto Federal de Educação, Ciência e Tecnologia, Campus de São Paulo.

\section{Arlete de Jesus Brito}

Livre docente em História e Educação Matemática pela Universidade Estadual "Júlio de Mesquita Filho" (UNESP). Atua como professora no departamento de Educação do Campus de Rio Claro e nos programas de pós-graduação em Educação Matemática e em Educação, nessa mesma Universidade.

\section{Sérgio Candido de Gouveia Neto}

Pós-doutorado em Educação Matemática - Universidade Estadual Paulista (Unesp-Rio Claro) (2017), Doutor em Educação Matemática - Universidade Estadual Paulista (Unesp-Rio Claro) (2015), Mestre em Ciências - Universidade de São Paulo (USP) (2006), Licenciado em Matemática Universidade Federal de Rondônia (2002). Professor Adjunto na Fundação Universidade Federal de Rondônia - Campus de Vilhena. Tem experiência na área de Educação Matemática, atuando principalmente nos seguintes temas: História da Educação Matemática; História da Matemática; Formação docente, Culturas, Saberes, Práticas e Diversidade da Amazônia. 

